NBER WORKING PAPER SERIES

\title{
MOVING BEYOND THE VALLEY OF DEATH: REGULATION AND VENTURE CAPITAL INVESTMENTS IN EARLY-STAGE BIOPHARMACEUTICAL FIRMS
}

\author{
Yujin Kim \\ Chirantan Chatterjee \\ Matthew J. Higgins \\ Working Paper 25202 \\ http://www.nber.org/papers/w25202 \\ NATIONAL BUREAU OF ECONOMIC RESEARCH \\ 1050 Massachusetts Avenue \\ Cambridge, MA 02138 \\ October 2018, Revised May 2019
}

We are grateful for helpful comments and suggestions from Bruce Weinberg, Sampsa Samila, Jian Wang, Lee Fleming, Ben Handel, Peter Kline, Ramana Nanda, Yongwook Paik, Steve Tadelis, Jagadeesh Sivadasan and Noam Yuchtman as well as seminar participants at Tsinghua University, Shanghai University of Finance and Economics, Peking University HSBC Business School, Waseda University, Hitotsubashi University, 2018 Barcelona GSE Workshop, Carey School of Business, Johns Hopkins University and the 2019 Bates White Lifesciences Symposium. Kim acknowledges financial support from the Ewing Marion Kauffman Dissertation Fellowship and the Korea Foundation of Advanced Studies Fellowship. Chatterjee acknowledges support from the Bharti \& Max Institute Research Fellowship in Public Policy and Healthcare at the Indian School of Business, the ICICI Bank Chair in Strategic Management at IIM Ahmedabad and 2018-2019 W. Glenn Campbell and Rita Ricardo-Campbell National Fellowship at the Hoover Institution, Stanford University. All errors remain our own. The views expressed herein are those of the authors and do not necessarily reflect the views of the National Bureau of Economic Research.

NBER working papers are circulated for discussion and comment purposes. They have not been peer-reviewed or been subject to the review by the NBER Board of Directors that accompanies official NBER publications.

(C) 2018 by Yujin Kim, Chirantan Chatterjee, and Matthew J. Higgins. All rights reserved. Short sections of text, not to exceed two paragraphs, may be quoted without explicit permission provided that full credit, including $\odot$ notice, is given to the source. 
Moving Beyond the Valley of Death: Regulation and Venture Capital Investments in Early-Stage Biopharmaceutical Firms

Yujin Kim, Chirantan Chatterjee, and Matthew J. Higgins

NBER Working Paper No. 25202

October 2018, Revised May 2019

JEL No. G24,L51,L65

\begin{abstract}
Can regulation reduce risks associated with investing in early-stage firms? Using the passage of the European Orphan Drug Act (EU-ODA), we examine this question in the biopharmaceutical industry. We provide causal evidence that venture capitalists (VCs) are more likely to invest in early-stage firms operating in sub-fields disproportionately affected by EU-ODA. The switch to early-stage investments appears strongest among VCs that previously faced greater levels of information asymmetry. We also find that the level of syndication declined for early-stage investments and exit performance improved. We conclude discussing the implications of our findings for public policy, entrepreneurship and innovation.

Yujin Kim

Shanghai Tech University

Huaxia Middle Road 393,

Pudong New District

Shanghai

China

yjkim@shanghaitech.edu.cn

Chirantan Chatterjee

Indian Institute of Management Ahmedabad

Room 15F, Wing 15, Heritage Campus

Ahmedabad

India

chirantan@gmail.com

Matthew J. Higgins

Scheller College of Business

Georgia Institute of Technology

800 West Peachtree Street

Atlanta, GA 30308

and NBER

matt.higgins@ @scheller.gatech.edu
\end{abstract}




\section{INTRODUCTION}

Extant research shows that many startups find it difficult to secure early-stage funding (Kerr and Nanda, 2011). A notable reason for this shortage is the difficulty in valuing these firms; they often involve novel scientific approaches or target new markets. They also often lack verifiable measures such as publications, patents, products, or sales that can be useful in objectively estimating the commercial feasibility and value of a venture. In the absence of such measures nascent firms may turn to alternative signals to convey quality (e.g., Hsu and Ziedonis, 2013; Higgins et al., 2011; Nicholson et al., 2005; Stuart et al., 1999; Audretsch and Stephan, 1996; Podolny, 1993). However, in these cases VCs often have to depend on their 'gut feelings' thereby making early-stage deal valuation as much an art as it is a science (Huang and Pearce, 2015).

This information asymmetry has led to the concern that VCs underfinance high-tech ventures that push the scientific frontier (e.g., Dimov and Murray, 2008; Parhankangas, 2007; Auerswald and Branscomb, 2003) resulting in a rotation from early-stage to late-stage investments (Lerner, 2009). Within the biopharmaceutical industry some have argued that VCs have begun to herd into similar technologies (Dimov and Murray, 2008; Auerswald and Branscomb, 2003). Others have suggested that the lack of early-stage funding has slowed the transition from the 'valley of death' thereby hindering productivity (Hudson and Khazragui, 2013).

This paper examines whether regulation can effectively be used to help alleviate these information asymmetries (Alvarez-Garrido, 2015; Milanesi et al., 2013; Schwienbacher, 2013) and drive investment towards early-stage firms. Empirical work linking regulation and venture capital is sparse. ${ }^{1}$ To fill this gap we exploit the introduction of the Orphan Drug Act in the

\footnotetext{
${ }^{1}$ Lerner (2000) considers the relationship between SBIR grants and subsequent VC funding. Gans and Stern (2003) find that SBIR awardees performed better in industries that attracted more VC investment. Finally, Samila and Sorenson (2011) show that federal R\&D funding and VC funding are complements.
} 
European Union (EU-ODA) in 2000. The EU-ODA was designed to incentivize and facilitate treatments for rare diseases. We present causal evidence that the EU-ODA increased early-stage $\mathrm{VC}$ investments by five percent, on average, for firms operating in biopharmaceutical sub-fields affected by the policy.

Unintendedly, the provisions of the EU-ODA provided investors credible signals about the scientific viability of novel drug candidates and clarity on their potential market value. We find that the dissipation of information asymmetries allowed VCs to shift from late-stage to earlystage investments when investing in EU-based startups, relative to US-based startups. This suggests that the expected return for EU-based startups increased relative to their counterparts in the US. Interestingly, we also find that new investments were more likely to come from US-based VCs as opposed to EU-based VCs. US-based VCs faced greater levels of information asymmetries due to their distance but it appears that the benefits from EU-ODA were a significant mechanism enough to induce cross-border investment.

In addition to causing VC investment to shift to earlier stages we also find that the level of syndication declined in early-round investments. This suggests that the informationprovisioning role of the EU-ODA, for early-stage startups, diminishes the need for peer input and evaluation that comes from syndication. It also suggests that benefits conferred by the EU-ODA outweigh the potential value-adding activities normally attributed to syndication $(e . g$., Chemmanur and Tian, 2011; Casamatta and Haritchabalet, 2007; Brander et al., 2002). Additionally the amount raised in these early rounds does not change after EU-ODA, which suggests that VCs had been using syndication as a way to decrease risk related to early-stage investments.

Lastly, we document a significant increase in exit performance for our focal EU-ODA treated firms. Notably, this increase was in the form of IPOs versus acquisitions, reversing a trend observed over the recent past (Gao et al., 2013). It appears that the signals conferred by the EUODA allowed VCs to select higher quality firms earlier and move them to IPO. This trend 
reversal should be viewed positively for investors since IPOs, on average, have higher returns than acquisitions (Smith et al., 2011). Importantly, we do not see any statistically significant difference in bankruptcies for firms affected by the EU-ODA. This suggests that the mitigation in risk due to the signals of the EU-ODA make these treated investments no more risky (in terms of failure) than control investments. This is important evidence that demonstrates the role regulation can play in mitigating market failures that may exist due to information asymmetries, opening the door to private investment.

\section{EUROPEAN UNION REGULATION 141/200: ORPHAN DRUG ACT}

The first Orphan Drug Act enacted anywhere was by the US in 1983 (US-ODA). It was intended to facilitate the development of treatments for rare diseases (Grabowski, 2005; Rohde, 2000). Most rare diseases remain "orphans" because market sizes are too small to justify their development costs. To solve this market failure, the US-ODA provided for a variety of incentives to firms. The considerable success of the US-ODA encouraged others, including the EU, to adopt similar legislation (Yin, 2008; Cheung et al., 2004; Lichtenberg and Waldfogel, 2003). The EU's adoption of their Orphan Drug Act occurred in December 1999 and it was implemented starting in January $2000 .^{2}$

In order to file for orphan designation in the EU the prevalence of the underlying disease must be below five per 10,000 of the EU population. Exceptions exist in cases where the expected return on investment is insufficient to justify a drug's development costs. The EU also considers whether the condition being treated is life threatening and if there exists a current treatment (or if the proposed treatment provides significant benefit over an existing drug). Key aspects of the application include discussions on the scientific rationale and medical plausibility of a drug candidate. Firms may file for orphan designation at any time during the development process up until they file for marketing authorization for the drug. In reality, however, applications need to

\footnotetext{
${ }^{2}$ EU Regulation 141/200: http://ec.europa.eu/health//sites/health/files/files/eudralex/vol1/reg_2000_141_cons-2009-07/reg_2000_141_cons-2009-07_en.pdf
} 
be filed 8-12 months prior to a submission for marketing approval given the time delays by the Committee for Orphan Medicinal Products (COMP) to process applications.

Receiving orphan drug status confers several key benefits to a firm including: protocol assistance and follow-up, reduced/waived regulatory fees, accelerated approval pathways and extensions to market exclusivity. Importantly, orphan status provides an assessment by the COMP of the medical plausibility of a drug candidate. It is this assessment that provides key scientific information to the market about the viability and risk of a drug candidate. In the EU, new drugs are awarded eight years of market exclusivity. The granting of orphan status confers another two years of market exclusivity, for a total of 10 years. ${ }^{3}$ Another two years is available (for a total of 12 years) if the drug targets a pediatric indication. ${ }^{4}$ Moreover, the granting of orphan status limits approvals of other drugs for the same indication unless they can be shown to provide significant benefit over an existing treatment (Hall and Carlson, 2014). ${ }^{5}$

All of these incentives were designed to encourage pharmaceutical innovation directed towards rare diseases. The evidence appears to suggest that the ODAs in the US and EU have been successful (Stockklausner et al., 2016). For example, since its passage in 1983, close to 3,000 drugs have received orphan drug status with 448 approvals in the US. In the EU, designations exceed 1,200 with nearly 100 approvals (Hall and Carlson, 2014). The ODAs are not without their detractors, however, where issues of gaming and high prices in the US have recently been called into question. ${ }^{6}$

Finally, the EU-ODA includes provisions that make some of the benefits tagged to protocol assistance and fee waivers more generous for small and medium size firms. As noted in

\footnotetext{
${ }^{3}$ In contrast, in the US chemical-based drugs are awarded five years of market exclusivity with orphan drug status conferring another two years for a total of seven years.

${ }^{4}$ During market exclusivity generics are unable to enter the market. While this confirms monopoly positions to these firms, drug prices are regulated in the EU.

${ }^{5}$ There are exceptions to these rules, for example if the original firm provides their consent or if they are unable to supply enough product. See Hall and Carlson (2014) for a more extensive discussion.

${ }^{6}$ For a discussion see: https://www.npr.org/sections/health-shots/2017/02/10/514373480/sen-grassleylaunches-inquiry-into-orphan-drug-laws-effect-on-prices
} 
Figure 1, the EU-ODA does not include the same kind of R\&D tax credits that exist in the US. It is important to note that the intention of the EU-ODA was to incentivize development of treatments for rare diseases; it was not intended per se to solve potential underfinancing of nascent firms. We could not find any relevant discussion of this topic in the legislative record. As such, for the purposes of providing an information-provisioning role to VCs and steering investment towards these firms, the EU-ODA can plausibly be viewed as an exogenous shock. This will be important for identification as parties might a priori behave strategically, a topic we return to below.

\section{VENTURE FINANCING OF EARLY-STAGE FIRMS}

Most biopharmaceutical startups lack the financial resources to take a product all the way to market. These firms largely depend on outside funding, especially during their nascent stages. It is at this stage of development, unfortunately, that conventional means of financing is severely limited (e.g., Budish et al., 2015; Murray, 1999; Myers and Majluf, 1984). Traditionally, VCs have filled this financing gap and carried firms forward to a liquidity event. Moreover, early-stage biopharmaceutical firms are notoriously difficult to value as many are working on innovative products at the frontier of technology and often lack publications, patents or products necessary to evaluate their commercial viability (Higgins et al., 2011; Gans et al., 2008). As such, investments in these firms often depend on the 'gut feelings' of VCs (Huang and Knight, 2017; Huang and Pearce, 2015) or other less traditional signals (e.g., Hsu and Ziedonis, 2013; Higgins et al., 2011; Nicholson et al., 2005; Stuart et al., 1999; Audretsch and Stephan, 1996; Podolny, 1993) .

These difficulties make investors seeking to fund early-stage startups vulnerable to information asymmetry problems such as adverse selection and moral hazard (e.g., Wu, 2016; Kerr et al., 2014). The problems compound when VCs do not have the specialized scientific knowledge to fully understand the nuances of startup technologies (Schwienbacher, 2013). Some have argued that VCs have responded to these challenges by switching from financing exploratory to exploitative ventures that are easier to understand and shifting from early- to late- 
stage firms (Alvarez-Garrido, 2015). The net effect of this herding behavior (Scharfstein and Stein, 1990) is that many firms suffer a financing gap in their early-stages or when they are at their so-called "valley of death" (Hudson and Khazragui, 2013).

\section{Signaling Effects of the ODA}

There is a vast literature on the role that signals play in markets dating back to Spence (1974). Effective signals can moderate the market failure problem caused by information asymmetry (e.g., Gorry and Useche, 2017; Heeley et al., 2007; Mann, 2004; Long, 2002). For example, in the context of entrepreneurial finance, prior work has demonstrated the signaling role of status (e.g., Stuart et al., 1999; Podolny, 1993), star-scientists (e.g., Higgins et al., 2011; Zucker et al., 2002; Zucker and Darby, 1997), alliance partners (Nicholson et al., 2005), venture capital backing (Meggison and Weiss, 1991), prestige of the underwriter (Higgins and Gulati, 2003; Meggison and Weiss, 1991) and university connections (Fuller and Rothaermel 2012; Audretsch and Stephan, 1996). Directly relevant to our study is the literature examining the role that regulation and policy play in providing government-backed signals so that the private sector can reasonably estimate the commercial and scientific viability of a project (e.g., Hoenig and Henkel, 2015; Useche, 2014; Hsu and Ziedonis, 2013). ${ }^{7}$

The EU-ODA provides two different signals that are beneficial in decreasing information asymmetries that we will categorize as scientific-based and market-based. Scientific-based signals are ones that help a VC understand and form estimates about the scientific viability of a project while market-based signals help estimate the economic viability of projects. If we consider a simple expected profit function: $E(\Pi)=\rho(T R-T C)$, where $E(\Pi)$ is defined as expected profit, TR is defined as the sum of all future discounted revenues, TC is the sum of all future discounted costs and $\rho$ represents some estimated probability that those revenues and costs will be realized. Effectively what the EU-ODA does is increase (or bring clarity to) TR, decrease

\footnotetext{
${ }^{7}$ Unlike prior literature that has studied the impact of government grants, awards and funding on subsequent venture capital financing (e.g., Islam et al., 2018), here the companies are not receiving funding. Rather, the signal is coming in the form of scientific validation and additional market protections.
} 
TC and improve estimates of $\rho$, all of which should either individually or collectively increase expected profits.

Expanding on the above, the early scientific review by regulators during the EU-ODA application process should improve clarity about the viability of a drug candidate. Because of this early review, orphan designation is often seen as a 'golden badge'. Essentially the EU-ODA transforms unobservable information about the quality of novel drugs into observable information, thereby decreasing the VC's cost of acquiring information necessary to make more informed decisions. Ultimately, this should translate into better approximations of transition probabilities and ultimately improved estimates of $\rho{ }^{8}$ The additional years of market exclusivity and limits on approvals of other drugs within the same therapeutic category should improve estimates of TR. It is important to note that the restrictions on other drugs do not include those that are shown to be superior. As such, revenue estimates still remain probabilistic. Finally, fee waivers and protocol assistance should reduce TC.

\section{Cross-border Venture Investing}

Entrepreneurial financing markets vary across regions. The VC market in the US is large, mature and relatively established compared to other regions. As such, US-based VCs regularly make cross-border investments to other regions, such as the EU and Asia, where entrepreneurial financing markets are still being grown (Iriyama et al., 2010; Loree and Guisinger, 1995). Due to the positive impacts of the foreign investments on entrepreneurial activities and innovation in the host country, many governments have pursued policies that make foreign investments more favorable (Kim and Li, 2014; Globerman and Shapiro, 1999).

Likewise, the information and signals provided by the EU-ODA acted in a similar manner, causing an increase in the flow of $\mathrm{VC}$ investments into EU-based firms from non-EU based investors. Compared to domestic VCs foreign VCs often face greater levels of information

\footnotetext{
${ }^{8}$ In a different context, research has demonstrated the positive signaling effects of regulatory certification in the case of the ISO 9000 Quality Management Standard (Terlaak and King, 2006).
} 
asymmetries when valuing local, early-stage firms (Vedula and Matusik, 2017; Dai et al., 2012).

In our context, EU-based VCs can more easily access information sources such as local networks, referrals from domestic firms or local government, and informal reputation that can be either directly or indirectly used to verify a local firm's quality. While information may be observable by local VCs, the same information may not be equivalently observable to foreign VCs due to factors such as geographic distance and/or cultural/linguistic differences (Bruton and Ahlstrom, 2003). Hence, the government-backed designations, such as that provided under EU-ODA, can turn less explicit information into more observable signals, thereby lowering the uncertainty surrounding US-based investments in EU-based firms (Zacharakis et al., 2007). We argue that this may be a positive externality created in our context for cross-border venture investments and we examine if this indeed holds in our analysis.

\section{Venture Capital Syndication}

VC deal syndication refers to two or more funds participating in an equity stake for a given investment and financing round. The argued benefits behind syndication include: improved deal quality selection; peer evaluation of technology; 'better' or more accurate valuations; improved guidance to investee firms; and a way to decrease VC portfolio risk (e.g., Gompers et al., 2016; Jääskeläinen et al., 2007; Wright and Lockett, 2003; Brander et al., 2002; Gompers and Lerner, 2000; Lerner, 1994). Unfortunately, these benefits do not come without potential costs. Casamatta and Haritchabalet (2007) argue that during the selection process VCs will 'tip their hand' and reveal potential deals to syndicate partners who themselves could turn into competitors for the deal.

Information and benefits provided by the EU-ODA could diminish the need for earlystage deal syndication in several ways. First, the medical and scientific review should decrease the need for peer evaluation of an underlying technology. The granting of orphan status should also serve as a signal of quality and improve overall deal selection, again reducing the need for peer evaluation. Second, the extensions to market exclusivity and limits on potential competition 
should improve a VC's ability to value the firm. Finally, the cost benefits of EU-ODA, on the margin, may decrease the need for funds making it less likely that a VC may want or need to spread risk across other firms.

\section{EMPIRICAL METHODOLOGY \& DATA}

\section{Methodology}

To tease out the causal relationship between EU-ODA and VC investments, we employ a difference-in-differences (DiD) approach to compare subfields primarily affected by EU-ODA to non-affected subfields, as we discuss more fully below. We estimate the following equation:

$$
\begin{aligned}
& \text { (1) } Y_{i j t}=\alpha_{j}+\gamma_{t}+X_{i}+\beta_{0}\left(\text { Drug related }_{j}\right)+\beta_{1}\left({\text { After } \left.O D A_{t}\right)}\right. \\
& +\beta_{2}\left\{\left(\text { Drug related }_{j}\right) *\left({\text { After } O D A_{t}}\right)\right\}+\varepsilon_{i j t}
\end{aligned}
$$

where $Y_{i j t}$ is defined as the various outcome variables we explore (i.e., timing of investment, the number of investors per round, invested amount per round and exit performance), $i$ indexes individual investments at the investee-round-investor level $(i \in\{1 \ldots 44,867\}), j$ indexes industry categories $(j \in\{1 \ldots 12\})$, and $t$ indexes the year $(t \in\{1989 \ldots 2011\})$. Drug related is a dummy variable that equals one if an investment is in the EU-ODA affected subfields (treatment group), zero otherwise. After $O D A$ is a dummy variable equal to one if an investment occurred after 2000, zero otherwise. $X_{i}$ is a vector of control variables that includes: location of the startup headquarters, location of the investor firm headquarters, and type of investors.

The coefficient of interest is $\beta_{2}$. The coefficient captures the difference in the outcome variables of the treatment group relative to the control group as a result of the treatment by the EU-ODA. To assign the treatment and the control groups, we use the fact that EU-ODA disproportionately affects firms pursuing development of novel drugs for human diseases. Among the investment categories in VentureExpert relating to medical, health and life sciences, we categorized the following into our treatment group: Biotech-Human, Med/Health Products, Medical Diagnostics, Medical Therapeutics and Pharmaceuticals. The control group consists of 
investment categories in the medical, health and life sciences not directly related to developing treatments for human disorders: Biosensors, Biotech Equipment, Biotech Other, Biotech Research, Biotech Animal, Biotech Industrial, and Med/Health Services. ${ }^{9}$

Finally, it is possible that the composition of VCs may somehow change after EU-ODA. For example, there may be entry of new VCs into drug-related fields for reasons other than the EU-ODA. If this happened then our $\mathrm{DiD}$ would only capture the impact of how investment patterns of entrant VCs differed from incumbent VCs, but not the changes of incumbent VCs caused by EU-ODA. To account for this possibility we report both OLS and fixed effect models with the intuition being that new VC entry will be controlled for by technology category, investor and time fixed effects. ${ }^{10}$

\section{Data and Variables}

Our data comes from VentureXpert and we start by collecting the population of global investments between 1989 and 2011 in the medical, health and life science categories. We exclude observations that do not disclose essential information such as: investment date, investment stage, industry category and other major characteristics of investing firms. This leaves us with a final dataset of 44,867 investments made to 6,643 startups by 3,072 investing firms. A time trend of investments by year is presented in Appendix Figure 1 and summary statistics are presented in Table 1.

Our primary unit of analysis is at the investee-investor-investment round level. Our startups, on average, receive investments over 3.9 rounds. Each round, on average, includes 4.8 investors and raises $\$ 12.8$ million. The average time difference between a startup's founding and an investment is 2,119 days (i.e., six years). Approximately 21 percent of investments are made in

\footnotetext{
${ }^{9}$ Modifications in the composition of the treatment and the control groups do not change the nature of results. For example, if we include Biotech Research and Biotech Other in the treatment instead of the control group our findings remain consistent. We include Medical Diagnostics in the treatment group because these technologies, such as biomarkers, are complements to drug development. If we move them from the treatment to control group our results remain unchanged.

${ }^{10}$ In addition to the OLS and the FE models we report in the paper we also report logit regressions in the Appendix. Results remain consistent.
} 
early-stage start-ups; 67 percent of investors and 80 percent of startups are located in the US, which aligns with the observation that the US has been the locus of global biopharmaceutical research.

To explore the timing of VC investments we construct three variables. First, we define Early-stage as a dummy variable equal to one if VentureExpert classifies an investment as earlystage, zero otherwise. Kaplan and Lerner (2016) note that defining what early-stage is sometimes is not straight forward in the context of the venture investments. However, VentureExpert captures this explicitly through a variable. ${ }^{11}$ We follow prior work (Atanasov et al (2007)) and use this variable in our analysis.

Second, because an early-stage investment can occur across firms of different ages we define Time to investment that measures the time between firm founding and the investment. If the EU-ODA causes investments to shift to early-stages, then the first variable will detect that effect. However, if the EU-ODA simply moves investments in the early-stage back further, this effect will be captured by our second variable. Lastly, we additionally define Time to initial investment by restricting samples to the set of the first investment that each startup ever received. This is to circumvent the issue of possible problems in how our data providers measure Early Stage and our results still remain consistent.

We control for the type of $\mathrm{VC}$ making the investment and categorize them as independent venture capital $(I V C)$, corporate venture capital $(C V C)$, government-backed venture capital $(G V C)$ or an angel investor (Angel). Again, we depend on VentureExpert's classification of VC type. We also control for whether the start-up was based in the US (US startup) or EU (EU startup) and whether the VC investor was based in the US (US investor) or EU (EU investor). In all cases these variables are defined as dummies that equal one if it falls within one of these categories, zero otherwise. In order to determine the number of VCs involved in syndication we count the number of investors participating in a single round (Number of investors).

\footnotetext{
${ }^{11}$ See for a variable list: https://vx.thomsonib.com/VxComponent/vxhelp/VEglossary.htm
} 
To investigate the investment performance of VCs, we define several dummy variables to capture both startup success and failure. An investment is considered a success if it leads to a liquidity event for the $\mathrm{VC}$. We define $M \& A$ as a dummy variable that equals one if a VC-backed investment exits through merger or acquisition, zero otherwise. We also define $I P O$ as a dummy variable that equals one if the VC-backed investment exits through an initial public offering, zero otherwise. Lastly, failure is defined as bankruptcy and we define a dummy variable, Bankruptcy, equal to one if a startup reports bankruptcy or it is defunct, zero otherwise.

Finally, we recognize that measuring the impact of EU-ODA on performance is challenging because startups founded prior to 2000 may continue to receive investments after 2000. To avoid any contamination we restrict our sample to startups that received an early-stage investment in the five years prior to EU-ODA to those that received an investment in five years after EU-ODA. Details are provided in performance analysis in Section 5.3 below.

\section{Identification}

Our identification strategy relies on the fact that the control group is not exposed to treatment in either period. To formally test the parallel trend assumption we take our pre-trend data (before 2000) and split it in half, defining the midpoint (1994) as an arbitrary treatment event and estimate our diff-in-diffs specification. If the parallel trend assumption is violated the coefficient $\beta_{2}$ will be statistically significant. The results for this placebo test are reported in Table 2 for each of our three different dependent variables. Across all models, the coefficient of interest, $\beta_{2}$, is not statistically significant. Hence, these placebo test results suggest that the parallel trends assumption is not violated.

\section{RESULTS}

\section{Impact of EU-ODA on Likelihood, Timing and Location of VC Investments}


Table 3 reports results related to the impact of EU-ODA on timing and location of venture capital investments. The dependent variable is Early-stage in Models 1 and 2, Time to investment in Models 3 and 4 and Time to initial investment in Models 5 and 6. Across all six models our coefficient of interest is $\beta_{2}$ or the interaction (Drug related $*$ After ODA). Given the number of controls in the regression we report our main independent variables in Table 3 while the full set of estimates are reported in Appendix Table 1. Models 1 and 2 show that VCs are 3.7 to 5 percent more likely to make early-stage investments in EU-ODA-related fields. This translates into roughly 2,000 new early-stage investments. Results in Models 3 to 6 show that VCs shift their investments forward by 1 to 2 years.

The coefficients from the OLS regressions in Models 1, 3 and 5 are greater than those from the fixed effect models in Models 2, 4 and 6. Recall that the OLS model takes into account both the change of pre-existing VCs as well as newly established VCs, while the fixed effect models include only pre-existing VCs. Taken together, the results imply that the EU-ODA promotes the entry of new VCs in EU-ODA-related fields, who fund much younger startups than incumbent investors do. ${ }^{12}$

Table 4 reports the variation of the EU-ODA impact over the location of VCs. We report results across two different dependent variables, Early-stage and Time to investment. Our main independent variables are displayed in Table 4 while the full set of estimates are reported in Appendix Table 6. In Models 1 and 2 we restrict the sample to investments in EU-based startups by EU-based VCs, while in Models 3 and 4 we restrict the sample to investments in EU-based startups by US-based VCs. ${ }^{13}$ The results suggest that the causal impact of the EU-ODA on

\footnotetext{
${ }^{12}$ To ensure that our results are not sensitive to our selection of time frames we repeat the analysis in Models 1 and 2 with three, five and seven year windows (Appendix Table 2). We repeat the same three, five and seven years time frame for the analysis in Models 3 and 4 (Appendix Table 3). In Appendix Table 4 we replicate Table 3 using a multinomial logit regression and in Appendix Table 5 we replicate Table 3 using alternative definitions of the treatment group. Results remain robust across these specifications.

${ }^{13} \mathrm{We}$ did not include the regressions with the subsamples of the first investments because the number of initial investments into EU startups made by US-based VCs is too small to run the fixed effect models.
} 
switching to early-stage investments is mainly driven by US-based VCs rather than EU-based VCs.

The fact that US-based VCs significantly increase early-stage investments in EU-based startups implies that foreign-based VCs suffered from greater levels of information asymmetries related to valuing EU-based startups relative to their EU-based counterparts. Geographic distance, cultural differences, and/or a lack of understanding about the local market possibly kept US-based VCs out of the market. The observable signals provided by the EU-ODA (directly and indirectly) help US-based VCs overcome the "liability of foreignness" and induce cross-border investments into EU-based startups. Consistent with prior work on signals (e.g., Conti et al., 2013a and 2013b; Higgins et al., 2011), the results in Table 4 seem to suggest that the information signaling effects of the EU-ODA have some dynamics inherent in them.

Relatedly, Table 5 separates the sample into VC investments made in EU-based startups and those made in US-based startups. Again, given the number of controls in the regression we report our main independent variables in Table 5 while the full set of estimates are reported in Appendix Table 7. Not surprisingly, the results show that the EU-ODA caused a switch towards younger firms in the EU (Model 2) but not in the US (Model 4). As expected, the effect is stronger and more significant among EU-based startups since they are more likely to benefit from orphan designation in their home market.

\section{Impact of ODA on Syndication of Venture Capital Investments}

Table 6 reports the changes in syndication behaviors of investors. Again, given the number of controls in the regression we report our main independent variables in Table 6 while the full set of estimates are reported in Appendix Table 8. Overall, Model 1 reports that VCs increase the use of syndication after EU-ODA in drug-related fields. However, this result is driven by late-stage investments. This can be seen when we split the sample into early- and late- 
stage deals. Results in Model 2 indicate that VCs are less likely to syndicate for early-stage deals; while in Model 3 we see an increase in deal syndication for late-stage deals. ${ }^{14}$

This diverging pattern suggests that the information conferred by the EU-ODA affects an investor's incentive for syndication differently across investment stages. A VC is likely to syndicate early-stage deals when there is less information available to evaluate a nascent investment opportunity. As a result, they depend on peer opinion. The signals created by the EUODA appear to be sufficient enough in quality to replace the need for peer opinion. Likewise, if the EU-ODA changes the expected profit of a start-up, they will become more valuable and command greater valuations in later rounds of financing. For these firms, we may see the level of syndication for late stage deals actually increase not because VCs need peer opinion but because VCs are necessary to pool their investments to meet the size of amount sought by the late-stage startups in pursuit of big exits.

Results in Table 7 support this view. Again, given the number of controls in the regression we report our main independent variables in Table 7 while the full set of estimates are reported in Appendix Table 10. In Model 1 we find an overall increase in amounts invested after EU-ODA. This result is completely driven by late-stage deals. In Model 3 we find that in EUODA affected fields the amount invested in late-stage deals increased by $\$ 1.2$ million. In Model 2 we see that the EU-ODA does not have a statistically significant impact on the amount invested in early-stage deals. Coupled with our prior findings in Table 6, this is important because the investment amount does not decrease on average, while investments are being shifted to an earlier stage (i.e., back over the 'valley of death') and the level of syndication is declining. In the

\footnotetext{
${ }^{14}$ To test the sensitivity, we repeat the analysis with three, five and seven year windows, which is reported in Appendix Table 9. The results remain robust to the modifications.
} 
absence of any type of risk-mitigation by the benefits of the EU-ODA we would expect to see the values of investments decline as they are shifted to an earlier stage. ${ }^{15}$

\section{Impact of EU-ODA on Performance of Venture Capital Investments}

In Table 8 we compare the exit performances of startups that received early-stage investments during the five years prior to the EU-ODA to those for the five years after the EUODA. As before, given the number of controls in the regression we report our main independent variables in Table 8 while the full set of estimates are reported in Appendix Table 11. Overall, we see significant differential exit performance between IPOs and acquisitions for our EU-ODA related fields. Specifically, in Model 2 we find that the rate of exit via IPO increased while in Model 1 the rate of exit via acquisition decreased. This pattern is a reversal of the general pattern observed by Gao et al. (2013). ${ }^{16}$ Given that biopharmaceutical IPOs tend to have higher returns than acquisitions, this suggests that VCs are able to maximize returns to investors (Gompers et al., 2016).

There can be two explanations for the improved exit performances. On one hand, the absolute values of early-stage startups funded by VCs after the EU-ODA could be greater than those funded prior to the EU-ODA, because the policy signals help VCs identify superior deals. On the other hand, the switch of exit mode toward IPO might suggest that those parties favoring exit via IPO appear to be winning any underlying tension relating to mode of exit. This result is interesting, especially given the conflict of interests between investors and startup founders within this market. In general, founders and management teams of startups tend to have a preference for exit via an IPO, while VCs tend to push for a timely liquidity event. ${ }^{17}$ Further,

\footnotetext{
${ }^{15}$ Relating back to our earlier example, $\mathrm{E}(\Pi)=\rho(\mathrm{TR}-\mathrm{TC})$, if investments are shifted back in time without any mitigation in risk, then $\rho$ would decrease thereby decreasing the expected value of a firm. This should lead to a lower valuation and, all else equal, a decline in investment.

${ }^{16}$ In Appendix Table 12 we replicate Table 8 over alternative time periods ( 3 and 7 years) and in Appendix Table 13 we replicate Table 8 using multinomial logit regressions. Results remain robust.

17 "It's very hard as a venture capitalist, as a professional board member, to tell a management team, 'you're going to build this company to be acquired. When these companies get swallowed by larger entities, the passion dies, the entrepreneurship dies," said Ted Schlein, a managing partner of Kleiner,
} 
among various types of investors, CVCs are reported to be more patient investor groups than individual VCs because CVCs are interested in the underlying technology rather than the financial return (Ceccagnoli et al., 2018; Park and Steensma, 2013). Collectively, these results suggest that the EU-ODA encourages management teams and investors to consider more costly and time-consuming options for mode of exit.

Finally, the results in Models 3 show that firms receiving early-stage investments after the EU-ODA do not have significantly greater hazards to exit via bankruptcy than the previously funded firms. This implies that the investment performance of VCs does not get worse as a result of the shift toward early-stage deals. In general, a shift towards earlier stage investments should come with increased risk. However, these results suggest that the signals and information conferred by EU-ODA were sufficient enough to reduce risk thereby allowing for investments to be made earlier or back across the 'valley of death'.

\section{CONCLUSION}

Given significant information asymmetries in early-stage investing, underinvestment can occur. Recent research suggests that VCs may be herding into less risky, later-stage projects. Such a shift can create funding gaps for early-stage firms. We explore the role that regulation may be able to play in helping early-stage firms go through the so-called valley-of -death. Using the regulatory setting of the EU and the passage of the Orphan Drug Act, we examine this question in the biopharmaceutical industry. To the best of our knowledge, this is one of the first papers to empirically demonstrate the causal impact from a reduction in information asymmetry through governmental regulation on the investment decisions of VCs.

We find that due to the benefits conferred by the EU-ODA VCs shift their investments towards earlier-stages. The magnitude of the impact appears stronger among the group of USbased VCs that previously faced greater information asymmetries in valuing EU-based startups,

Perkins, Caufield \& Byers: https://www.forbes.com/2010/03/05/venture-capital-ipo-entrepreneurs-financewharton.html\#5765046a7137 
compared to local investors. We also find that the level of syndication decreases during this shift. Importantly, the average amount invested per round does not change suggesting that the information conferred by the EU-ODA replaced the need for peer evaluation. Exit performance appears to improve with an increased probability of IPO and no greater risk of bankruptcy resulting from the shift towards earlier stage investments. Taken together, our results appear to demonstrate that regulation can play a significant role in mitigating valuation problems relating to information asymmetry and, thus, helping drive private investment back across the 'valley of death'.

Our findings also have important policy implications given that many countries have made establishing a solid ecosystem for entrepreneurship a priority. Unfortunately, for some technologies and industries, such as biopharmaceuticals, significant information asymmetries exist making the valuation of early-stage firms difficult. If these firms are unable to communicate the genuine value of their early-stage innovations, they may end up being disproportionately underfinanced compared to other startups for which information is more readily available and discernable. This could dampen the incentives of entrepreneurs and early-stage firms to pursue high-risk, high-reward type of innovations in important science-based sectors like biopharmaceuticals. Our results here demonstrate that policy has a role in correcting this market failure.

Our project, however, is not without limitations. First, we do not study systematically how entry and exit of VCs might be driving our results, although we partly aim to address it econometrically by using a fixed effects strategy. If it is the case that new VCs are responsible for shifting the nature of VC activity towards early-stage startups, then future studies can build on our intuition to investigate the moderating role of industry evolution among VCs in conjunction with regulation, such as the EU-ODA. Second, as VCs shift their investment focus to early-stage startups, they might need to come up with new investment strategies and/or governance structures to manage their portfolio. While our study partly examines the changes in deal syndication 
strategies of VCs, the shift towards less syndication in early-stages and more syndication in latestages may cause investment patterns, due to factors such as risk, to change. To the extent this has unintended consequences remains to be seen.

Finally, while we do our best to tease out the causal impact of the EU-ODA, it is still possible that the group of firms in drug-related biopharmaceutical fields may differ from the group in non-drug-related fields in some unobservable ways. Future work could also consider extending our findings to sectors beyond biopharmaceuticals to other emerging fields like artificial intelligence or climate change. A cross-industry study would also be useful to help determine if our results are generalizable or whether the biopharmaceutical industry remains a 'black duck'. Related to this, it would be meaningful to examine what types of VC-specific characteristics lead to the tendency toward financing younger innovations, such as the background of partners, reputation or previous experiences in relevant markets. As always, much remains to be done.

\section{References}

Alvarez-Garrido, E. 2015. The value translation model: A theory of venture growth and innovation. Academy of Management Proceedings, No. 1, 17910.

Atanasov, V., Ivanov, V., \& Litvak, K. 2007. The impact of litigation on venture capitalist reputation (No. w13641). National Bureau of Economic Research.

Audretsch, D., Stephan, P. 1996. Company-scientist locational links: the case of biotechnology. American Economic Review, 86(3), 641-652.

Auerswald, P. E., Branscomb, L. M. 2003. Valleys of death and Darwinian seas: Financing the invention to innovation transition in the United States. The Journal of Technology Transfer, 28(34), 227-239.

Brander, J. A., Amit, R., Antweiler, W. 2002. Venture-capital syndication: Improved venture selection versus the value-added hypothesis. Journal of Economics \& Management Strategy, 11(3), 423-452.

Bruton, G. D., Ahlstrom, D. 2003. An institutional view of China's venture capital industry: Explaining differences between China and the West. Journal of Business Venturing, 18(2), 233259. 
Budish, E., Roin, B. N., Williams, H. 2015. Do firms underinvest in long-term research? Evidence from cancer clinical trials. American Economic Review, 105(7), 2044-2085.

Casamatta, C., Haritchabalet, C. 2007. Experience, screening and syndication in venture capital investments. Journal of Financial Intermediation, 16(3), 368-398.

Ceccagnoli, M., Higgins, M.J., Kang, H. 2018. Corporate venture capital as a real option in the market for technology. Strategic Management Journal, forthcoming.

Chemmanur, T., Tian, X. 2011. Peer monitoring, syndication, and the dynamics of venture capitalist interactions. Available at SSRN: https://ssrn.com/abstract=1343116

Cheung, R. Y., Cohen, J. C., \& Illingworth, P. 2004. Orphan drug policies: implications for the United States, Canada, and developing countries. Health Law Journal, 12, 183.

Conti, A., Thursby, M., Rothaermel, F. T. 2013a. Show me the right stuff: Signals for high-tech startups. Journal of Economics \& Management Strategy, 22(2), 341-364.

Conti, A., Thursby, J., Thursby, M. 2013b. Patents as signals for startup financing. The Journal of Industrial Economics, 61(3), 592-622.

Dai, N., Jo, H., Kassicieh, S. 2012. Cross-border venture capital investments in Asia: Selection and exit performance. Journal of Business Venturing 27(6), 666-684.

Dimov, D., Murray, G. 2008. Determinants of the incidence and scale of seed capital investments by venture capital firms. Small Business Economics, 30(2), 127-152.

Fuller, A.W., Rothaermel, F.T. 2012. When stars shine: The effects of faculty founders on new technology ventures. Strategic Entrepreneurship Journal, 6(3), 220-235.

Gans, J., Stern, S. 2003. When does funding research by smaller firms bear fruit?: Evidence from the SBIR program. Economics of Innovation and New Technology, 12(4), 361-384.

Gans, J. S., Hsu, D. H., \& Stern, S. 2008. The impact of uncertain intellectual property rights on the market for ideas: Evidence from patent grant delays. Management Science, 54(5), 982-997.

Gao, X., Ritter, J. R., Zhu, Z. 2013. Where have all the IPOs gone?. Journal of Financial and Quantitative Analysis, 48(6), 1663-1692.

Globerman, S., Shapiro, D.M. 1999. The impact of government policies on foreign direct investment: The Canadian experience. Journal of International Business Studies, 30(3), 513-532.

Gompers, P., Gornall, W., Kaplan, S. N., Strebulaev, I. A. 2016. How do venture capitalists make decisions? National Bureau of Economic Research, Working Paper No. 22587:

http://www.nber.org/papers/w22587.

Gompers, P., Lerner, J. 2000. The determinants of corporate venture capital success: Organizational structure, incentives, and complementarities. In Concentrated Corporate Ownership, 17-54. University of Chicago Press, Chicago, IL. 
Gorry, P., Useche, D. 2017. Orphan Drug Designations as Valuable Intangible Assets for IPO Investors in Pharma-Biotech Companies. In Economic Dimensions of Personalized and Precision Medicine. University of Chicago Press, Chicago, IL.

Grabowski, H. G. 2005. Increasing R\&D incentives for neglected diseases: Lessons from the Orphan Drug Act. In International Public Goods and Transfer of Technology Under a Globalized Intellectual Property Regime. Cambridge University Press, Cambridge, UK.

Hall, A. K., Carlson, M. R. 2014. The current status of orphan drug development in Europe and the US. Intractable \& Rare Diseases Research, 3(1), 1-7.

Heeley, M. B., Matusik, S. F., Jain, N. 2007. Innovation, appropriability, and the underpricing of initial public offerings. Academy of Management Journal, 50(1), 209-225.

Higgins, M. J., Stephan, P. E., Thursby, J. G. 2011. Conveying quality and value in emerging industries: Star scientists and the role of signals in biotechnology. Research Policy, 40(4), 605617.

Higgins, M., Gulati, R. 2003. Getting off to a good start: the effects of upper echelon affiliations on underwriter prestige. Organization Science, 14(3), 244-263.

Hoenig, D., Henkel, J. 2015. Quality signals? The role of patents, alliances, and team experience in venture capital financing. Research Policy, 44(5), 1049-1064.

Hsu, D., Ziedonis, R. 2013. Resources as dual sources of advantage: Implications for valuing entprenrenueiral firm patents. Strategic Management Journal, 34(7), 761-781.

Huang, L., Knight, A. P. 2017. Resources and relationships in entrepreneurship: an exchange theory of the development and effects of the entrepreneur-investor relationship. Academy of Management Review, 42(1), 80-102.

Huang, L., Pearce , J.L. 2015. Managing the unknowable the effectiveness of early-stage investor gut feel in entrepreneurial investment decisions. Administrative Science Quarterly, 60(4), 634670.

Hudson, J., Khazragui, H. F. 2013. Into the valley of death: research to innovation. Drug Discovery Today, 18(13-14), 610-613.

Islam, M., Fremeth, A., Marcus, A. 2018. Signaling by early stage startups: US government research grants and venture capital funding. Journal of Business Venturing, 33(1), 35-51.

Iriyama, A., Li, Y., Madhavan, R. 2010. Spiky globalization of venture capital investments: The influence of prior human networks. Strategic Entrepreneurship Journal, 4(2), 128-145.

Jääskeläinen, M., Maula, M., Murray, G. 2007. Profit distribution and compensation structures in publicly and privately funded hybrid venture capital funds. Research Policy, 36(7), 913-929.

Kaplan, S. N., \& Lerner, J. 2016. Venture capital data: Opportunities and challenges (No. w22500). National Bureau of Economic Research. 
Kerr, W. R., Nanda, R. 2011. Financing constraints and entrepreneurship. Handbook of Research on Innovation and Entrepreneurship, 88.

Kerr, W. R., Nanda, R., Rhodes-Kropf, M. 2014. Entrepreneurship as experimentation. Journal of Economic Perspectives, 28(3), 25-48.

Kim, P. H., Li, M. 2014. Injecting demand through spillovers: Foreign direct investment, domestic socio-political conditions, and host-country entrepreneurial activity. Journal of Business Venturing, 29(2), 210-231.

Lerner, J. 1994. The syndication of venture capital investments. Financial Management, 16-27.

Lerner, J. 2000. The government as venture capitalist: the long-run impact of the SBIR program. The Journal of Private Equity, 55-78.

Lerner, J. 2009. Boulevard of Broken Dreams: Why Public Efforts to Boost Entrepreneurship and Venture Capital Have Failed--and What to Do About It. Princeton University Press, Princeton, NJ.

Lichtenberg, F. R., Waldfogel, J. 2003. Does misery love company? Evidence from pharmaceutical markets before and after the Orphan Drug Act. National Bureau of Economic Research, Working Paper No. 9750: http://www.nber.org/papers/w9750.

Long, C. 2002. Patent signals. The University of Chicago Law Review, 625-679.

Loree, D.W., Guisinger, S.E. 1995. Policy and non-policy determinants of US equity foreign direct investment. Journal of International Business Studies, 26(2), 281-299.

Mann, R. J. 2004. Do patents facilitate financing in the software industry. Texas Law Review, 83: 961.

Meggison, W., Weisss, K. 1991. Venture capitalist certification in initial public offerings. Journal of Finance, 46(3), 879-901.

Milanesi, G., Pesce, G., El Alabi, E. 2013. Technology-based startup valuation using real options with Edgeworth expansion. Journal of Finance and Accounting, 1(2), 54-61.

Murray, G. 1999. Early-stage venture capital funds, scale economies and public support. Venture Capital: An International Journal of Entrepreneurial Finance, 1(4), 351-384.

Myers, S. C., Majluf, N.S. 1984. Corporate financing and investment decisions when firms have information that investors do not have. Journal of Financial Economics, 13(2), 187-221.

Nicholson, S., Danzon, P., \& McCullough, J. 2005. Biotech-pharmaceutical alliances as a signal of asset and firm quality. The Journal of Business, 78(4), 1433-1464.

Parhankangas, A. 2007. An overview of research on early stage venture capital: Current status and future directions. Handbook of Research on Venture Capital 1: 253. Edward Elgar Publishing, Northampton, MA. 
Park, H. D., Steensma, H. K. 2013. The selection and nurturing effects of corporate investors on new venture innovativeness. Strategic Entrepreneurship Journal, 7(4), 311-330.

Podolny, J. M. 1993. A status-based model of market competition. American Journal of Sociology, 98(4), 829-872.

Rohde, D. D. 2000. Orphan drug act: An engine of innovation-at what cost. Food \& Drug Law Journal, 55: 125.

Samila, S., Sorenson, O. 2011. Venture capital, entrepreneurship, and economic growth. The Review of Economics and Statistics, 93(1), 338-349.

Scharfstein, D. S., Stein, J. C. 1990. Herd behavior and investment. The American Economic Review, 465-479.

Schwienbacher, A. 2013. The entrepreneur's investor choice: The impact on later-stage firm development. Journal of Business Venturing, 28(4), 528-545.

Smith, R., Robert, P., Vijay, S. 2011. VC fund financial performance: The relative importance of IPO and M\&A exits and exercise of abandonment options. Financial Management, 40(4), 10291065.

Spence, M. 1973. Job market signaling. The Quarterly Journal of Economics, 87(3), 355-374.

Stockklausner, C., Lampert, A., Hoffmann, G. F., Ries, M. 2016. Novel treatments for rare cancers: the US orphan drug act is delivering-a cross-sectional analysis. The Oncologist, 21(4), 487-493.

Stuart, T. E., Hoang, H., Hybels, R. C. 1999. Interorganizational endorsements and the performance of entrepreneurial ventures. Administrative Science Quarterly, 44(2), 315-349.

Terlaak, A., King, A.A. 2006. The effect of certification with the ISO 9000 Quality Management Standard: A signaling approach. Journal of Economic Behavior \& Organization, 60(4), 579-602.

Useche, D. 2014. Are patents signals for the IPO market? An EU-US comparison for the software industry. Research Policy, 43(8), 1299-1311.

Vedula, S., Matusik, S. F. 2017. Geographic, network, and competitor social cues: evidence from US venture capitalists internationalization decisions. Strategic Entrepreneurship Journal, 11(4), 393-421.

Wright, M., Lockett, A. 2003. The structure and management of alliances: Syndication in the venture capital industry. Journal of Management Studies, 40(8), 2073-2102.

Wu, A. 2016. Organizational decision-making and information: Angel investments by venture capital partners. In Academy of Management Proceedings (Vol. 2016, No. 1, p. 11043). Briarcliff Manor, NY 10510: Academy of Management.

Yin, W. 2008. Market incentives and pharmaceutical innovation. Journal of Health Economics, 27(4), 1060-1077. 
Zacharakis, A.L., McMullen, J.S., Shepherd, D.A. 2007. Venture capitalists' decision policies across three countries: an institutional theory perspective. Journal of International Business Studies, 38(5), 691-708.

Zucker, L.G., Darby, M.R. 1997. Individual action and the demand for institutions: Star scientists and institutional transformation. American Behavioral Scientist, 40, 502-153.

Zucker, L.G., Darby, M.R., Armstrong, J. 2002. Commercializing knowledge: University science, knowledge capture and firm performance in biotechnology. Management Science, 48, 138-153. 
Figure 1. Comparison of the EU-ODA to the US-ODA.

\begin{tabular}{|c|c|c|}
\hline Items & EU-ODA & US-ODA \\
\hline Timetable & Timetable published by EMA & Any time; no defined timetable \\
\hline Prevalence criteria & $\begin{array}{l}\text { Disease or condition affects }<5 \text { in } \\
10,000 \text { persons in the EU }\end{array}$ & $\begin{array}{l}\text { Disease or condition affects }<200,000 \\
\text { persons in the US }\end{array}$ \\
\hline Sponsor criteria & Proof of establishment in EU & Not required \\
\hline $\begin{array}{l}\text { Key aspects of the } \\
\text { application }\end{array}$ & $\begin{array}{l}\text { - Medical plausibility } \\
\text { - Prevalence } \\
\text { - Justification of significant benefit or } \\
\text { why other methods are not satisfactory }\end{array}$ & $\begin{array}{l}\text { - Scientific rationale } \\
\text { - Prevalence }\end{array}$ \\
\hline Benefits & $\begin{array}{l}\text { - Protocol assistance (scientific advice) } \\
\text { - } 10 \text { years of market exclusivity } \\
\text { - Reduced regulatory fees } \\
\text { - None } \\
\text { - Funding may be available from other } \\
\text { sources within the EU } \\
\text { - Access to the centralized } \\
\text { authorization procedure in the EU }\end{array}$ & $\begin{array}{l}\text { - Protocol assistance } \\
\text { - } 7 \text { years of market exclusivity } \\
\text { - Reduced/waived regulatory fees } \\
\text { - Tax credit on clinical trials } \\
\text { - Specific subsidies for clinical trials } \\
\text { - None }\end{array}$ \\
\hline $\begin{array}{l}\text { Harmonized } \\
\text { procedure }\end{array}$ & \multicolumn{2}{|c|}{$\begin{array}{l}\text { - Parallel applications for orphan designation to the EU, the US and Japan } \\
\text { - Parallel scientific advice from the EU EMA and the US FDA } \\
\text { - Submission of a single annual development report to the US and the EU }\end{array}$} \\
\hline
\end{tabular}


Table 1. Descriptive statistics.

\begin{tabular}{lccccc}
\hline Variable & $\mathrm{N}$ & Mean & St. Dev. & Min & Max \\
\hline Round ID & 44,867 & 3.936 & 2.770 & 1 & 26 \\
Number of investors in a round & 44,867 & 4.857 & 3.486 & 1 & 27 \\
Amount invested in a round (\$1K) & 44,867 & $12,843.550$ & $10,161.580$ & 1 & 32,572 \\
Drug-related (\%) & 44,867 & 0.807 & 0.394 & 0 & 1 \\
After ODA & 44,867 & 0.742 & 0.437 & 0 & 1 \\
Time to investment & 44,867 & $2,119.388$ & $1,870.077$ & 0 & 15,611 \\
Early-stage (\%) & 44,867 & 0.213 & 0.409 & 0 & 1 \\
Late-stage (\%) & 44,867 & 0.566 & 0.496 & 0 & 1 \\
IVC & 44,867 & 0.916 & 0.277 & 0 & 1 \\
CVC & 44,867 & 0.055 & 0.229 & 0 & 1 \\
Angel & 44,867 & 0.003 & 0.051 & 0 & 1 \\
GVC & 44,867 & 0.007 & 0.081 & 0 & 1 \\
EU startups (\%) & 44,867 & 0.139 & 0.346 & 0 & 1 \\
US startups (\%) & 44,867 & 0.800 & 0.400 & 0 & 1 \\
M\&A (\%) & 44,867 & 0.342 & 0.474 & 0 & 1 \\
Bankruptcy (\%) & 44,867 & 0.075 & 0.264 & 0 & 1 \\
IPO (\%) & 44,867 & 0.214 & 0.410 & 0 & 1 \\
EU investor (\%) & 44,867 & 0.144 & 0.351 & 0 & 1 \\
US investor (\%) & 44,867 & 0.669 & 0.471 & 0 & 1 \\
\hline
\end{tabular}


Table 2. Pre-trend tests. The unit of observation is at the investee-investor-round level observations. The dependent variable is Early-stage in Models 1 and 2, Time to investment in Models 3 and 4, and Time to initial investment in Models 5 and 6. The time period covers 1989 to 1999 with the arbitrary placebo event year of 1994. A non-significant coefficient on (Drugrelated*After 1994) would suggest that the parallel trend assumption is not violated. Standard errors are clustered at the investing firm level. ${ }^{*} \mathrm{p}<0.10 ; * * \mathrm{p}<0.05 ; * * \mathrm{p}<0.01$.

Dependent variables

\begin{tabular}{|c|c|c|c|c|c|c|}
\hline & \multicolumn{2}{|c|}{ Early-stage } & \multicolumn{2}{|c|}{ Time to investment } & \multicolumn{2}{|c|}{ Time to initial investment } \\
\hline & $\begin{array}{l}O L S \\
\text { (1) }\end{array}$ & $\begin{array}{c}\text { Fixed effect } \\
\text { (2) }\end{array}$ & $\begin{array}{l}O L S \\
\text { (3) }\end{array}$ & $\begin{array}{c}\text { Fixed effect } \\
\text { (4) }\end{array}$ & $\begin{array}{c}O L S \\
(5)\end{array}$ & $\begin{array}{c}\text { Fixed effect } \\
\text { (6) }\end{array}$ \\
\hline Drug-related & $\begin{array}{c}0.081^{* * *} \\
(0.024)\end{array}$ & $\begin{array}{c}0.036 \\
(0.026)\end{array}$ & $\begin{array}{c}-68.263 \\
(114.892)\end{array}$ & $\begin{array}{c}50.968 \\
(123.937)\end{array}$ & $\begin{array}{c}-577.231^{* * * *} \\
(208.163)\end{array}$ & $\begin{array}{l}-483.121^{*} \\
(249.278)\end{array}$ \\
\hline After 1994 & $\begin{array}{l}-0.044 \\
(0.030)\end{array}$ & $\begin{array}{l}-0.071^{*} \\
(0.036)\end{array}$ & $\begin{array}{l}329.836^{* * *} \\
(121.709)\end{array}$ & $\begin{array}{c}479.293^{* * *} \\
(142.985)\end{array}$ & $\begin{array}{l}514.454^{* *} \\
(212.747)\end{array}$ & $\begin{array}{c}207.018 \\
(272.274)\end{array}$ \\
\hline $\begin{array}{l}\text { Drug-related } \\
* \text { *After } 1994\end{array}$ & $\begin{array}{l}-0.025 \\
(0.027)\end{array}$ & $\begin{array}{l}-0.046 \\
(0.029)\end{array}$ & $\begin{array}{c}24.789 \\
(136.772)\end{array}$ & $\begin{array}{c}75.976 \\
(164.246)\end{array}$ & $\begin{array}{c}-31.372 \\
(237.975)\end{array}$ & $\begin{array}{c}319.798 \\
(347.970)\end{array}$ \\
\hline Controls & YES & YES & YES & YES & YES & YES \\
\hline Category FE & YES & YES & YES & YES & YES & YES \\
\hline Year FE & YES & YES & YES & YES & YES & YES \\
\hline Investor FE & NO & YES & NO & YES & NO & YES \\
\hline Observations & 11,561 & 11,561 & 11,561 & 11,561 & 2,416 & 2,416 \\
\hline $\mathrm{R}^{2}$ & 0.015 & 0.152 & 0.017 & 0.279 & 0.066 & 0.496 \\
\hline
\end{tabular}


Table 3. Timing of VC investments. The unit of observation is at the investee-investor-round level. The dependent variable is Early-stage in Models 1 and 2, Time to investment in Models 3 and 4, and Time to initial investment in Models 5 and 6. The coefficients from Models 3 to 6 can be interpreted as days. All models include our full set of controls and complete results are reported in Appendix Table 1. Standard errors are clustered at the investing firm level. ${ }^{*} \mathrm{p}<0.10,{ }^{* *} \mathrm{p}<0.05$, and ${ }^{* * * *} \mathrm{p}<0.01$.

Dependent variables

\begin{tabular}{lcccccc}
\hline & \multicolumn{2}{c}{ Early-stage } & \multicolumn{2}{c}{ Time to investment } & \multicolumn{2}{c}{ Time to initial investment } \\
& OLS & Fixed effect & OLS & Fixed effect & OLS & Fixed effect \\
& $(1)$ & $(2)$ & $(3)$ & $(4)$ & $(5)$ & $(6)$ \\
\hline Drug-related & $0.057^{* * *}$ & 0.007 & $-360.329^{* * *}$ & 0.525 & $-871.868^{* * *}$ & -256.747 \\
& $(0.015)$ & $(0.016)$ & $(84.805)$ & $(99.472)$ & $(123.561)$ & $(162.972)$ \\
After ODA & $-0.072^{* * * *}$ & $-0.116^{* * *}$ & $2,220.333^{* * *}$ & $2,242.097^{* * *}$ & $2,376.560^{* * *}$ & $1,577.302^{* * *}$ \\
& $(0.021)$ & $(0.024)$ & $(107.492)$ & $(135.589)$ & $(215.410)$ & $(298.998)$ \\
Drug-related & $0.050^{* * *}$ & $0.037^{*}$ & $-675.434^{* * *}$ & $-369.563^{* * *}$ & $-653.943^{* * *}$ & $-278.859^{*}$ \\
$*$ After ODA & & & & & & \\
& $(0.017)$ & $(0.020)$ & $(94.234)$ & $(99.074)$ & $(134.804)$ & $(165.085)$ \\
& & & & & YES & YES \\
\hline Controls & YES & YES & YES & YES & YES & YES \\
Category FE & YES & YES & YES & YES & YES & YES \\
Year FE & YES & YES & YES & YES & NO & YES \\
Investor FE & NO & YES & NO & 44,867 & 8,933 & 8,933 \\
\hline Observations & 44,867 & 44,867 & 44,867 & 0.363 & 0.134 & 0.548 \\
$\mathrm{R}^{2}$ & 0.020 & 0.131 & 0.099 & & & \\
\hline
\end{tabular}


Table 4. Impact of EU-ODA on early-stage investment by origin of VCs. The unit of observation is at the investee-investor-round level. This table replicates our main specification on split samples by the origin of the VC. Models 1 and 2 include investments made by EU-based VCs into EU-based startups while Models 3 and 4 include investments by US-based VCs into EU-based startups. The dependent variable in Models 1 and 3 is Early-stage while the dependent variable in Models 2 and 4 is Time to investment. All models include our full set of controls and complete results are reported in Appendix Table 6. Standard errors are clustered at the investing firm level. ${ }^{*} \mathrm{p}<0.10,{ }^{* *} \mathrm{p}<0.05$, and ${ }^{* * *} \mathrm{p}<0.01$.

EU-based VCs to EU-based startup

US-based VCs to EU-based startup

Dependent variables

\begin{tabular}{lcccc}
\hline & $\begin{array}{c}\text { Early-stage } \\
(1)\end{array}$ & $\begin{array}{c}\text { Time to inv. } \\
(2)\end{array}$ & $\begin{array}{c}\text { Early-stage } \\
(3)\end{array}$ & $\begin{array}{c}\text { Time to inv. } \\
(4)\end{array}$ \\
\hline Drug-related & $0.136^{*}$ & $-620.537^{*}$ & -0.077 & $2,488.061^{*}$ \\
& $(0.080)$ & $(347.650)$ & $(0.048)$ & $(1,476.213)$ \\
After ODA & 0.076 & $2,430.350^{* * *}$ & -0.286 & $3,474.732^{* * *}$ \\
& $(0.180)$ & $(390.199)$ & $(0.263)$ & $(1,305.922)$ \\
Drug-related & -0.010 & 170.629 & $0.324^{* * *}$ & $-1,481.601^{* *}$ \\
$*$ After ODA & $(0.076)$ & $(277.629)$ & $(0.110)$ & $(749.362)$ \\
& YES & YES & YES & YES \\
\hline Investor FE & YES & YES & YES & YES \\
Category FE & YES & YES & YES & YES \\
Year FE & 4,695 & 4,695 & 809 & 809 \\
\hline Observations & 0.229 & 0.479 & 0.411 & 0.564 \\
$\mathrm{R}^{2}$ & & &
\end{tabular}


Table 5. Impact of EU-ODA on early-stage investment by origin of startups. The unit of observation is at the investee-investor-round level. This table replicates our main specification on split samples by the origin of the start-up. Models 1 and 2 include investments in EU-based startups while Models 3 and 4 include those in US-based startups. The dependent variable in Models 1 and 3 is Early-stage while the dependent variable in Models 2 and 4 is Time to investment. All models include our full set of controls and complete results are reported in Appendix Table 7. Standard errors are clustered at the industry category level. ${ }^{*} \mathrm{p}<0.10,{ }^{* *} \mathrm{p}<0.05$, and ${ }^{* * *} \mathrm{p}<0.01$.

EU-based startups only

US-based startups only

Dependent variables

\begin{tabular}{lcccc}
\hline & Early stage & Time to inv. & Early stage & Time to inv. \\
& $(1)$ & $(2)$ & $(3)$ & $(4)$ \\
\hline Drug-related & $0.168^{* *}$ & $-1,170.304^{* * *}$ & $0.042^{*}$ & -272.758 \\
& $(0.080)$ & $(207.057)$ & $(0.025)$ & $(257.074)$ \\
After ODA & -0.120 & $2,545.285^{* * *}$ & -0.063 & $2,133.798^{* * *}$ \\
& $(0.234)$ & $(467.040)$ & $(0.042)$ & $(441.487)$ \\
Drug-related & 0.087 & $-522.078^{* *}$ & 0.037 & -596.852 \\
*After ODA & $(0.065)$ & $(252.448)$ & $(0.032)$ & $(428.999)$ \\
& YES & YES & YES & YES \\
\hline Controls & YES & YES & YES & YES \\
Category FE & YES & YES & YES & YES \\
Year FE & 6,223 & 6,223 & 35,876 & 35,876 \\
\hline Observations & 0.054 & 0.175 & 0.020 & 0.090 \\
$\mathrm{R}^{2}$ & & & &
\end{tabular}


Table 6. Changes in the VC investment syndication after EU-ODA. The unit of observation is at the investee-investor-round level. The dependent variable across all Models is Number of investors. Model 1 includes our full sample while Models 2 and 3 split the sample into early- and late-stage, respectively. All models include our full set of controls and complete results are reported in Appendix Table 8. Standard errors are clustered at the investing firm level. ${ }^{*} \mathrm{p}<0.10,{ }^{* *} \mathrm{p}<0.05$, and ${ }^{* * *} \mathrm{p}<0.01$.

Dependent variable

\begin{tabular}{lccc}
\multicolumn{3}{c}{ Dependent variable } \\
\hline & $(1)$ & Number of investors & $(3)$ \\
& Total & Early-stage & Late-stage \\
\hline Drug-related & $0.468^{* * *}$ & $0.954^{* * *}$ & $0.658^{* * *}$ \\
& $(0.160)$ & $(0.247)$ & $(0.195)$ \\
After ODA & $-1.356^{* * *}$ & $-2.990^{* * *}$ & $-0.580^{*}$ \\
& $(0.250)$ & $(0.490)$ & $(0.313)$ \\
Drug-related*After & $0.454^{* * *}$ & $-0.475^{* *}$ & $0.606^{* * *}$ \\
ODA & $(0.136)$ & $(0.237)$ & $(0.186)$ \\
& YES & YES & YES \\
Controls & YES & YES & YES \\
Category FE & YES & YES & YES \\
Year FE & YES & YES & YES \\
Investor FE & 44,867 & 9,547 & 25,375 \\
\hline Observations & 0.265 & 0.369 & 0.354 \\
$\mathrm{R}^{2}$ & &
\end{tabular}


Table 7. Changes in the invested amount after EU-ODA. The level of observation is at the investee-round level. The dependent variable across all models is Invested amount in round $(\$ 1 \mathrm{k})$. Model 1 includes our full sample while Models 2 and 3 split the sample into early- and late-stage, respectively. All models include our full set of controls and complete results are reported in Appendix Table 10. Standard errors are clustered at the investee firm level. ${ }^{*} \mathrm{p}<0.10,{ }^{* *} \mathrm{p}<0.05$, and ${ }^{* * *} \mathrm{p}<0.01$.

Dependent variable

Investment amount in a round $(\$ 1 \mathrm{~K})$

(1)

(2)

(3)

Total

Early-stage

Late-stage

Drug-related

$2,145.008^{* * *}$

$2,100.302^{* * *}$

$2,461.805^{* * * *}$

(393.253)

(882.699)

(515.129)

After ODA

$-4,268.836^{* * *}$

$-2,301.149$

$-3,338.689^{* * *}$

(691.035)

$(1,411.083)$

(999.937)

Drug-related*After ODA

$791.456^{*}$

$-1,153.093$

$1,198.666^{* * *}$

(434.347)

(923.312)

(562.095)

\begin{tabular}{lccc}
\hline Controls & YES & YES & YES \\
Category FE & YES & YES & YES \\
Year FE & YES & YES & YES \\
\hline Observations & 20,386 & 4,399 & 10,479 \\
$\mathrm{R}^{2}$ & 0.040 & 0.025 & 0.056 \\
\hline
\end{tabular}


Table 8. Exit performance of early-stage startups. The level of observation is at the investeeinvestor-round level. Models 1-3 are run utilizing fixed effects. The dependent variable in Model 1 is defined as $M \& A$. The dependent variable in Model 2 is defined as $I P O$ and the dependent variable in Model 3 is defined as Bankruptcy. All models include our full set of controls and complete results are reported in Appendix Table 11. Standard errors are clustered at the investing firm level. ${ }^{*} \mathrm{p}<0.10,{ }^{* *} \mathrm{p}<0.05$, and ${ }^{* * *} \mathrm{p}<0.01$.

\begin{tabular}{lccc}
\hline & M\&A & IPO & Bankruptcy \\
& $(1)$ & $(2)$ & $(3)$ \\
\hline Drug-related & 0.043 & -0.017 & -0.093 \\
& $(0.073)$ & $(0.054)$ & $(0.074)$ \\
After ODA & 0.086 & $-0.316^{* * *}$ & $-0.139^{* *}$ \\
& $(0.076)$ & $(0.070)$ & $(0.066)$ \\
Drug-related* & $-0.132^{*}$ & $0.136^{* *}$ & 0.020 \\
After ODA & $(0.068)$ & $(0.053)$ & $(0.062)$ \\
& YES & YES & YES \\
\hline Controls & YES & YES & YES \\
Category FE & YES & YES & YES \\
Year FE & YES & YES & YES \\
Investor FE & 4,291 & 4,291 & 4,291 \\
\hline Observations & 0.331 & 0.346 & 0.296 \\
$\mathrm{R}^{2}$ & & &
\end{tabular}


Appendix Figure 1. Time Trend of VC Investment in the Biopharmaceutical Industry.

Time trend of VC investment in the biopharmaceutical industry

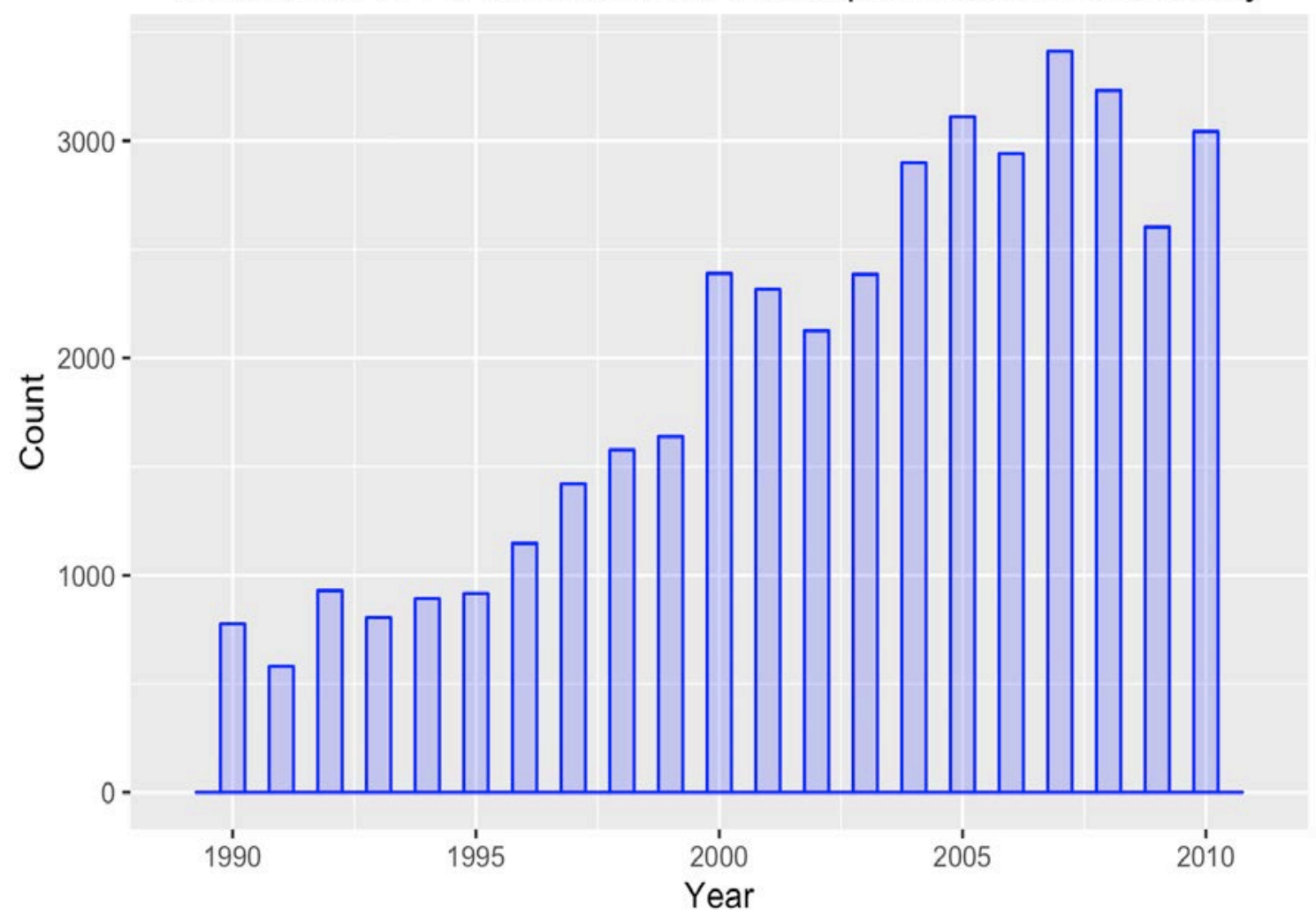


Appendix Table 1. VCs switch to Early Stage Investments with EU-ODA - All Controls. This table replicates Table 3 reporting the coefficient estimates for our full set of fixed effects at the technology category and year level. In addition this table reports coefficient estimates for all our controls in the baseline specification. Standard errors are clustered at the investing firm level. ${ }^{*} \mathrm{p}<0.10 ;{ }^{* *} \mathrm{p}<0.05 ;{ }^{* * *} \mathrm{p}<0.01$.

\begin{tabular}{|c|c|c|c|c|c|c|}
\hline & \multicolumn{6}{|c|}{ Dependent variables } \\
\hline & \multicolumn{2}{|c|}{ Early-stage } & \multicolumn{2}{|c|}{$\begin{array}{l}\text { Time to } \\
\text { investment }\end{array}$} & \multicolumn{2}{|c|}{ Time to initial investment } \\
\hline & $\begin{array}{l}O L S \\
(1)\end{array}$ & $\begin{array}{l}\text { Fixed effect } \\
\text { (2) }\end{array}$ & $\begin{array}{l}O L S \\
(3)\end{array}$ & $\begin{array}{c}\text { Fixed effect } \\
\text { (4) }\end{array}$ & $\begin{array}{l}O L S \\
(5)\end{array}$ & $\begin{array}{c}\text { Fixed effect } \\
\text { (6) }\end{array}$ \\
\hline Drug-related & $\begin{array}{c}0.057^{* * *} \\
(0.015)\end{array}$ & $\begin{array}{c}0.007 \\
(0.016)\end{array}$ & $\begin{array}{c}-360.329^{* * *} \\
(84.805)\end{array}$ & $\begin{array}{c}0.525 \\
(99.472)\end{array}$ & $\begin{array}{c}-871.868^{* * *} \\
(123.561)\end{array}$ & $\begin{array}{l}-256.747 \\
(162.972)\end{array}$ \\
\hline After ODA & $\begin{array}{c}-0.072^{* * *} \\
(0.021)\end{array}$ & $\begin{array}{c}-0.116^{* * *} \\
(0.024)\end{array}$ & $\begin{array}{c}2,220.333^{* * *} \\
(107.492)\end{array}$ & $\begin{array}{c}2,242.097^{* * *} \\
(135.589)\end{array}$ & $\begin{array}{c}2,376.560^{* * * *} \\
(215.410)\end{array}$ & $\begin{array}{c}1,577.302^{* * *} \\
(298.998)\end{array}$ \\
\hline $\begin{array}{c}\text { Drug-related } \\
* \text { After ODA }\end{array}$ & $\begin{array}{l}0.050^{* * * *} \\
(0.017)\end{array}$ & $\begin{array}{l}0.037^{*} \\
(0.020)\end{array}$ & $\begin{array}{c}-675.434^{* * *} \\
(94.234)\end{array}$ & $\begin{array}{c}-369.563^{* * *} \\
(99.074)\end{array}$ & $\begin{array}{c}-653.943^{* * *} \\
(134.804)\end{array}$ & $\begin{array}{l}-278.859^{*} \\
(165.085)\end{array}$ \\
\hline EU startups & $\begin{array}{c}0.020 \\
(0.017)\end{array}$ & $\begin{array}{l}0.059^{* *} \\
(0.024)\end{array}$ & $\begin{array}{l}-148.278 \\
(106.762)\end{array}$ & $\begin{array}{c}-598.053^{* * *} \\
(119.565)\end{array}$ & $\begin{array}{l}-155.895 \\
(127.689)\end{array}$ & $\begin{array}{c}-755.547^{* * *} \\
(235.317)\end{array}$ \\
\hline US startups & $\begin{array}{c}0.002 \\
(0.015)\end{array}$ & $\begin{array}{c}0.017 \\
(0.021)\end{array}$ & $\begin{array}{c}-270.107^{* *} \\
(106.040)\end{array}$ & $\begin{array}{c}-406.150^{* * *} \\
(125.464)\end{array}$ & $\begin{array}{c}-532.089^{* * *} \\
(119.955)\end{array}$ & $\begin{array}{c}-626.768^{* * *} \\
(212.098)\end{array}$ \\
\hline Biosensors & $\begin{array}{c}0.182^{* * * *} \\
(0.030)\end{array}$ & $\begin{array}{c}0.092^{* * *} \\
(0.033)\end{array}$ & $\begin{array}{c}- \\
1,509.644^{* * * *} \\
(142.160)\end{array}$ & $\begin{array}{c}-724.875^{* * *} \\
(163.061)\end{array}$ & $\begin{array}{c}- \\
1,828.669^{* * * *} \\
(193.149)\end{array}$ & $\begin{array}{l}-489.056^{*} \\
(251.220)\end{array}$ \\
\hline $\begin{array}{c}\text { Biotech } \\
\text { Equipment }\end{array}$ & $\begin{array}{l}0.094^{* * * *} \\
(0.016)\end{array}$ & $\begin{array}{c}0.016 \\
(0.019)\end{array}$ & $\begin{array}{c}-883.017^{* * *} \\
(109.594)\end{array}$ & $\begin{array}{l}-256.320^{* *} \\
(121.448)\end{array}$ & $\begin{array}{c}- \\
1,342.040^{* * *} \\
(179.090)\end{array}$ & $\begin{array}{l}-154.741 \\
(218.316)\end{array}$ \\
\hline Biotech Other & $\begin{array}{l}0.401^{* * *} \\
(0.078)\end{array}$ & $\begin{array}{c}0.262^{* * *} \\
(0.075)\end{array}$ & $\begin{array}{c}- \\
1,625.864^{* * * *} \\
(312.288)\end{array}$ & $\begin{array}{l}-628.857^{*} \\
(344.637)\end{array}$ & $\begin{array}{c}- \\
1,858.277^{* * *} \\
(278.037)\end{array}$ & $\begin{array}{l}-384.756 \\
(328.909)\end{array}$ \\
\hline $\begin{array}{l}\text { Biotech } \\
\text { Research }\end{array}$ & $\begin{array}{l}0.137^{* * *} \\
(0.020)\end{array}$ & $\begin{array}{l}0.069^{* * *} \\
(0.021)\end{array}$ & $\begin{array}{c}- \\
1,284.648^{* * *} \\
(106.418)\end{array}$ & $\begin{array}{c}-666.304^{* * *} \\
(122.082)\end{array}$ & $\begin{array}{c}- \\
1,595.982^{* * *} \\
(159.595)\end{array}$ & $\begin{array}{c}-742.286^{* * *} \\
(198.993)\end{array}$ \\
\hline Biotech-Animal & $\begin{array}{c}0.174^{* * *} \\
(0.026)\end{array}$ & $\begin{array}{l}0.107^{* * *} \\
(0.031)\end{array}$ & $\begin{array}{c}-871.073^{* * *} \\
(123.270)\end{array}$ & $\begin{array}{c}-447.534^{* * *} \\
(154.125)\end{array}$ & $\begin{array}{c}- \\
1,461.492^{* * *} \\
(187.515)\end{array}$ & $\begin{array}{c}-867.157^{* * *} \\
(265.695)\end{array}$ \\
\hline $\begin{array}{l}\text { Biotech- } \\
\text { Industrial }\end{array}$ & $\begin{array}{l}0.116^{* * * *} \\
(0.019)\end{array}$ & $\begin{array}{c}0.027 \\
(0.022)\end{array}$ & $\begin{array}{c}-968.685^{* * *} \\
(150.518)\end{array}$ & $\begin{array}{l}-263.135^{*} \\
(155.846)\end{array}$ & $\begin{array}{c}- \\
1,176.827^{* * *} \\
(206.588)\end{array}$ & $\begin{array}{l}-53.501 \\
(262.977)\end{array}$ \\
\hline $\begin{array}{l}\text { Biotech- } \\
\text { Human }\end{array}$ & $\begin{array}{l}0.075^{* * * *} \\
(0.009)\end{array}$ & $\begin{array}{l}0.059^{* * * *} \\
(0.011)\end{array}$ & $\begin{array}{c}-303.108^{* * *} \\
(42.091)\end{array}$ & $\begin{array}{c}-214.279^{* * * *} \\
(40.890)\end{array}$ & $\begin{array}{c}-620.636^{* * *} \\
(56.239)\end{array}$ & $\begin{array}{c}-235.312^{* * *} \\
(62.441)\end{array}$ \\
\hline Med/Health & -0.007 & -0.005 & $510.341^{* * *}$ & $438.911^{* * *}$ & $863.768^{* * *}$ & $738.490^{* * *}$ \\
\hline
\end{tabular}




\begin{tabular}{|c|c|c|c|c|c|c|}
\hline \multicolumn{7}{|l|}{ Products } \\
\hline & (0.009) & $(0.010)$ & (75.180) & (68.772) & (127.422) & (148.625) \\
\hline laceutical & $\begin{array}{l}0.032^{* * *} \\
(0.010)\end{array}$ & $\begin{array}{c}0.036^{* * *} \\
(0.010)\end{array}$ & $\begin{array}{c}-239.392^{* * *} \\
(54.964)\end{array}$ & $\begin{array}{c}-309.493^{* * *} \\
(53.759)\end{array}$ & & \\
\hline 1990 & $\begin{array}{l}-0.061^{* *} \\
(0.027)\end{array}$ & $\begin{array}{l}-0.062^{* * *} \\
(0.031)\end{array}$ & $\begin{array}{c}240.268^{* * *} \\
(73.389)\end{array}$ & $\begin{array}{c}298.041^{* * * *} \\
(73.221)\end{array}$ & $\begin{array}{c}-50.232 \\
(189.587)\end{array}$ & $\begin{array}{c}179.576 \\
(237.435)\end{array}$ \\
\hline 1991 & $\begin{array}{l}-0.076^{* * *} \\
(0.025)\end{array}$ & $\begin{array}{l}-0.071^{* *} \\
(0.028)\end{array}$ & $\begin{array}{c}394.401^{* * *} \\
(77.118)\end{array}$ & $\begin{array}{c}479.515^{* * *} \\
(76.836)\end{array}$ & $\begin{array}{c}58.525 \\
(192.958)\end{array}$ & $\begin{array}{c}81.064 \\
(223.908)\end{array}$ \\
\hline 1992 & $\begin{array}{c}-0.112^{* * *} \\
(0.023)\end{array}$ & $\begin{array}{c}-0.111^{* * * *} \\
(0.026)\end{array}$ & $\begin{array}{c}283.625^{* * *} \\
(63.111)\end{array}$ & $\begin{array}{c}315.994^{* * * *} \\
(67.918)\end{array}$ & $\begin{array}{l}426.661^{* *} \\
(177.162)\end{array}$ & $\begin{array}{c}258.651 \\
(226.801)\end{array}$ \\
\hline 1993 & $\begin{array}{c}-0.086^{* * *} \\
(0.023)\end{array}$ & $\begin{array}{c}-0.088^{* * *} \\
(0.026)\end{array}$ & $\begin{array}{l}161.936^{* *} \\
(81.108)\end{array}$ & $\begin{array}{c}226.319^{* * *} \\
(82.587)\end{array}$ & $\begin{array}{c}139.092 \\
(174.092)\end{array}$ & $\begin{array}{c}341.908 \\
(218.337)\end{array}$ \\
\hline 1994 & $\begin{array}{c}-0.115^{* * *} \\
(0.023)\end{array}$ & $\begin{array}{c}-0.121^{* * *} \\
(0.026)\end{array}$ & $\begin{array}{c}255.323^{* * *} \\
(70.001)\end{array}$ & $\begin{array}{c}320.095^{* * *} \\
(79.892)\end{array}$ & $\begin{array}{l}320.772^{*} \\
(163.977)\end{array}$ & $\begin{array}{c}314.801 \\
(205.607)\end{array}$ \\
\hline 1995 & $\begin{array}{c}-0.090^{* * * *} \\
(0.027)\end{array}$ & $\begin{array}{c}-0.107^{* * *} \\
(0.030)\end{array}$ & $\begin{array}{c}335.524^{* * *} \\
(82.233)\end{array}$ & $\begin{array}{c}416.237^{* * * *} \\
(94.113)\end{array}$ & $\begin{array}{c}194.035 \\
(174.376)\end{array}$ & $\begin{array}{c}158.840 \\
(227.449)\end{array}$ \\
\hline 1996 & $\begin{array}{c}-0.122^{* * *} \\
(0.021)\end{array}$ & $\begin{array}{c}-0.141^{* * *} \\
(0.024)\end{array}$ & $\begin{array}{c}232.463^{* * *} \\
(79.219)\end{array}$ & $\begin{array}{c}302.620^{* * * *} \\
(94.263)\end{array}$ & $\begin{array}{c}281.867 \\
(184.265)\end{array}$ & $\begin{array}{c}288.343 \\
(244.443)\end{array}$ \\
\hline 1997 & $\begin{array}{c}-0.072^{* * *} \\
(0.021)\end{array}$ & $\begin{array}{c}-0.080^{* * * *} \\
(0.023)\end{array}$ & $\begin{array}{c}367.264^{* * *} \\
(73.857)\end{array}$ & $\begin{array}{c}382.142^{* * *} \\
(94.630)\end{array}$ & $\begin{array}{c}543.426^{* * *} \\
(161.795)\end{array}$ & $\begin{array}{c}236.390 \\
(201.599)\end{array}$ \\
\hline 1998 & $\begin{array}{c}-0.063^{* * *} \\
(0.023)\end{array}$ & $\begin{array}{c}-0.082^{* * *} \\
(0.026)\end{array}$ & $\begin{array}{c}276.953^{* * *} \\
(78.401)\end{array}$ & $\begin{array}{c}333.154^{* * * *} \\
(90.144)\end{array}$ & $\begin{array}{l}419.375^{* * *} \\
(139.100)\end{array}$ & $\begin{array}{l}396.722^{* *} \\
(181.003)\end{array}$ \\
\hline 1999 & $\begin{array}{l}-0.054^{* *} \\
(0.021)\end{array}$ & $\begin{array}{c}-0.071^{* * *} \\
(0.025)\end{array}$ & $\begin{array}{c}398.264^{* * *} \\
(81.548)\end{array}$ & $\begin{array}{l}449.971^{* * * *} \\
(103.528)\end{array}$ & $\begin{array}{c}616.923^{* * *} \\
(182.828)\end{array}$ & $\begin{array}{l}634.271^{* * *} \\
(242.226)\end{array}$ \\
\hline 2000 & $\begin{array}{c}-0.043^{* *} \\
(0.018)\end{array}$ & $\begin{array}{l}-0.017 \\
(0.021)\end{array}$ & $\begin{array}{c}- \\
1,248.739^{* * *} \\
(68.552)\end{array}$ & $\begin{array}{c}- \\
1,467.519^{* * *} \\
(79.850)\end{array}$ & $\begin{array}{c}- \\
1,438.575^{* * *} \\
(166.963)\end{array}$ & $\begin{array}{c}-922.487^{* * * *} \\
(233.967)\end{array}$ \\
\hline 2001 & $\begin{array}{c}-0.077^{* * *} \\
(0.017)\end{array}$ & $\begin{array}{l}-0.047^{* *} \\
(0.020)\end{array}$ & $\begin{array}{c}- \\
1,014.967^{* * *} \\
(70.693)\end{array}$ & $\begin{array}{c}- \\
1,213.383^{* * *} \\
(77.688)\end{array}$ & $\begin{array}{c}- \\
1,279.629^{* * *} \\
(163.862)\end{array}$ & $\begin{array}{c}-751.852^{* * *} \\
(218.396)\end{array}$ \\
\hline 2002 & $\begin{array}{c}-0.065^{* * *} \\
(0.016)\end{array}$ & $\begin{array}{l}-0.033^{*} \\
(0.018)\end{array}$ & $\begin{array}{c}- \\
1,138.517^{* * *} \\
(64.839)\end{array}$ & $\begin{array}{c}- \\
1,348.966^{* * *} \\
(71.778)\end{array}$ & $\begin{array}{c}- \\
1,143.860^{* * *} \\
(172.741)\end{array}$ & $\begin{array}{c}-877.030^{* * *} \\
(228.864)\end{array}$ \\
\hline 2003 & $\begin{array}{c}-0.072^{* * *} \\
(0.016)\end{array}$ & $\begin{array}{l}-0.046^{* *} \\
(0.018)\end{array}$ & $\begin{array}{c}-890.307^{* * *} \\
(64.416)\end{array}$ & $\begin{array}{c}- \\
1,050.505^{* * *} \\
(66.750)\end{array}$ & $\begin{array}{c}-821.901^{* * *} \\
(190.067)\end{array}$ & $\begin{array}{l}-383.885 \\
(234.497)\end{array}$ \\
\hline 2004 & $\begin{array}{l}-0.100^{* * *} \\
(0.014)\end{array}$ & $\begin{array}{c}-0.072^{* * *} \\
(0.016)\end{array}$ & $\begin{array}{c}-822.266^{* * *} \\
(61.971)\end{array}$ & $\begin{array}{c}-991.764^{* * *} \\
(62.230)\end{array}$ & $\begin{array}{c}-917.963^{* * *} \\
(174.845)\end{array}$ & $\begin{array}{c}-644.753^{* * *} \\
(215.054)\end{array}$ \\
\hline 2005 & $\begin{array}{l}-0.084^{* * *} \\
(0.015)\end{array}$ & $\begin{array}{c}-0.055^{* * *} \\
(0.015)\end{array}$ & $\begin{array}{c}-645.104^{* * *} \\
(69.931)\end{array}$ & $\begin{array}{c}-773.974^{* * *} \\
(67.558)\end{array}$ & $\begin{array}{c}-737.285^{* * *} \\
(191.669)\end{array}$ & $\begin{array}{l}-406.094^{*} \\
(233.812)\end{array}$ \\
\hline 2006 & $-0.096^{* * *}$ & $-0.076^{* * *}$ & $-766.737^{* * *}$ & $-864.926^{* * *}$ & $-945.555^{* * *}$ & $-610.640^{* * *}$ \\
\hline
\end{tabular}




\begin{tabular}{ccccccc} 
& $(0.014)$ & $(0.015)$ & $(58.774)$ & $(57.192)$ & $(171.336)$ & $(217.663)$ \\
$\mathbf{2 0 0 7}$ & $-0.067^{* * *}$ & $-0.049^{* * *}$ & $-414.369^{* * *}$ & $-544.313^{* * *}$ & $-489.551^{* * * *}$ & -179.454 \\
& $(0.012)$ & $(0.013)$ & $(61.747)$ & $(59.233)$ & $(176.770)$ & $(211.559)$ \\
$\mathbf{2 0 0 8}$ & $-0.053^{* * *}$ & $-0.044^{* * *}$ & $-379.554^{* * *}$ & $-475.508^{* * *}$ & $-523.703^{* * *}$ & -166.573 \\
& $(0.012)$ & $(0.013)$ & $(64.613)$ & $(59.472)$ & $(174.057)$ & $(201.293)$ \\
\multirow{2}{2}{$\mathbf{2 0 0 9}$} & $-0.028^{* * *}$ & -0.021 & $-255.605^{* * *}$ & $-291.237^{* * *}$ & $-594.630^{* * * *}$ & $-366.876^{*}$ \\
& $(0.014)$ & $(0.014)$ & $(63.156)$ & $(59.534)$ & $(188.739)$ & $(219.754)$ \\
\multirow{2}{*}{$\mathbf{2 0 1 0}$} & $-0.050^{* * *}$ & $-0.042^{* * *}$ & -58.338 & $-95.350^{*}$ & -115.394 & 105.703 \\
& $(0.011)$ & $(0.012)$ & $(57.373)$ & $(53.554)$ & $(196.669)$ & $(225.655)$ \\
\multirow{2}{*}{ Constant } & $0.209^{* * * *}$ & & $1,988.813^{* * *}$ & & $2,071.478^{* * *}$ & \\
& $(0.025)$ & & $(134.174)$ & & $(200.713)$ & \\
\hline Observations & 44,867 & 44,867 & 44,867 & 44,867 & 8,933 & 8,933 \\
$\mathbf{R}^{2}$ & 0.020 & 0.131 & 0.099 & 0.363 & 0.134 & 0.548 \\
\hline
\end{tabular}


Appendix Table 2. VCs switching to Early-Stage Investments with EU-ODA Given Alternative Time Periods Before/After EU-ODA This table replicates Model (1) of Table 3 by restricting the sample to three different time periods in our analysis, 3,5 , and 7 years before and after EU-ODA. We also report here the coefficient estimates for our full set of fixed effects at the technology category and year level. In addition, this table reports coefficient estimates for all our controls in the baseline specification. Standard errors are clustered at the investing firm level.

${ }^{*} \mathrm{p}<0.10 ;{ }^{* * *} \mathrm{p}<0.05 ;{ }^{* * *} \mathrm{p}<0.01$.

\begin{tabular}{|c|c|c|c|}
\hline & \multicolumn{3}{|c|}{ Dependent variables } \\
\hline & \multicolumn{3}{|c|}{ Investment into early-stage startups (binary) } \\
\hline & $\begin{array}{c}3 \text { years } \\
\text { before/after } \\
\text { (1) }\end{array}$ & $\begin{array}{c}5 \text { years } \\
\text { before/after } \\
\text { (2) }\end{array}$ & $\begin{array}{c}7 \text { years } \\
\text { before/after } \\
\text { (3) }\end{array}$ \\
\hline Drug-related & $0.095^{* * *}$ & $0.062^{* * * *}$ & $0.058^{* * * *}$ \\
\hline After ODA & $\begin{array}{l}-0.024 \\
(0.019)\end{array}$ & $\begin{array}{l}-0.010 \\
(0.016)\end{array}$ & $\begin{array}{l}-0.038^{* *} \\
(0.019)\end{array}$ \\
\hline $\begin{array}{c}\text { Drug-related } \\
* \text { After ODA }\end{array}$ & -0.022 & 0.004 & $0.027^{* *}$ \\
\hline & $(0.018)$ & $(0.014)$ & $(0.013)$ \\
\hline EU startups & $\begin{array}{l}-0.026 \\
(0.020)\end{array}$ & $\begin{array}{c}-0.024 \\
(0.016)\end{array}$ & $\begin{array}{l}-0.022 \\
(0.013)\end{array}$ \\
\hline US startups & $\begin{array}{c}-0.052^{* * *} \\
(0.018)\end{array}$ & $\begin{array}{l}-0.035^{* *} \\
(0.015)\end{array}$ & $\begin{array}{c}-0.032^{* * *} \\
(0.012)\end{array}$ \\
\hline IVC & $\begin{array}{c}-0.065^{* * *} \\
(0.022)\end{array}$ & $\begin{array}{l}-0.038^{* *} \\
(0.018)\end{array}$ & $\begin{array}{c}-0.025 \\
(0.016)\end{array}$ \\
\hline CVC & $\begin{array}{l}-0.045^{*} \\
(0.026)\end{array}$ & $\begin{array}{l}-0.017 \\
(0.021)\end{array}$ & $\begin{array}{l}-0.016 \\
(0.018)\end{array}$ \\
\hline Angel & $\begin{array}{c}0.032 \\
(0.072)\end{array}$ & $\begin{array}{c}0.088 \\
(0.055)\end{array}$ & $\begin{array}{l}0.118^{* *} \\
(0.048)\end{array}$ \\
\hline GVC & $\begin{array}{c}-0.212^{* * *} \\
(0.048)\end{array}$ & $\begin{array}{c}-0.169^{* * *} \\
(0.040)\end{array}$ & $\begin{array}{c}-0.135^{* * *} \\
(0.034)\end{array}$ \\
\hline Biosensors & $\begin{array}{c}0.347^{* * *} \\
(0.055)\end{array}$ & $\begin{array}{l}0.210^{* * * *} \\
(0.038)\end{array}$ & $\begin{array}{l}0.210^{* * *} \\
(0.031)\end{array}$ \\
\hline Biotech Equipment & $\begin{array}{c}0.082^{* * * *} \\
(0.022)\end{array}$ & $\begin{array}{l}0.070^{* * * *} \\
(0.017)\end{array}$ & $\begin{array}{l}0.073^{* * * *} \\
(0.015)\end{array}$ \\
\hline Biotech Other & $\begin{array}{c}0.444^{* * * *} \\
(0.069)\end{array}$ & $\begin{array}{c}0.381^{* * * *} \\
(0.060)\end{array}$ & $\begin{array}{c}0.399^{* * * *} \\
(0.057)\end{array}$ \\
\hline Biotech Research & $\begin{array}{l}0.136^{* * *} \\
(0.021)\end{array}$ & $\begin{array}{l}0.119^{* * * *} \\
(0.017)\end{array}$ & $\begin{array}{l}0.130^{* * * *} \\
(0.015)\end{array}$ \\
\hline Biotech-Animal & $\begin{array}{l}0.280^{* * * *} \\
(0.026)\end{array}$ & $\begin{array}{l}0.214^{* * * *} \\
(0.023)\end{array}$ & $\begin{array}{l}0.199^{* * * *} \\
(0.020)\end{array}$ \\
\hline
\end{tabular}




\begin{tabular}{|c|c|c|c|}
\hline Biotech-Industrial & $\begin{array}{l}0.057^{*} \\
(0.033)\end{array}$ & $\begin{array}{l}0.092^{* * * *} \\
(0.026)\end{array}$ & $\begin{array}{l}0.124^{* * * *} \\
(0.020)\end{array}$ \\
\hline Biotech-Human & $\begin{array}{c}0.053^{* * *} \\
(0.009)\end{array}$ & $\begin{array}{l}0.040^{* * * *} \\
(0.007)\end{array}$ & $\begin{array}{c}0.048^{* * * *} \\
(0.006)\end{array}$ \\
\hline Med/Health Products & $\begin{array}{l}-0.032^{* *} \\
(0.014)\end{array}$ & $\begin{array}{l}-0.014 \\
(0.011)\end{array}$ & $\begin{array}{c}-0.008 \\
(0.009)\end{array}$ \\
\hline Pharmaceutical & $\begin{array}{l}0.056^{* * *} \\
(0.012)\end{array}$ & $\begin{array}{c}0.047^{* * *} \\
(0.009)\end{array}$ & $\begin{array}{c}0.039^{* * *} \\
(0.008)\end{array}$ \\
\hline 1994 & & & $\begin{array}{l}-0.029 \\
(0.019)\end{array}$ \\
\hline 1995 & & & $\begin{array}{l}-0.007 \\
(0.019)\end{array}$ \\
\hline 1996 & & & $\begin{array}{c}-0.039^{* *} \\
(0.018)\end{array}$ \\
\hline 1997 & & $\begin{array}{l}0.035^{* *} \\
(0.014)\end{array}$ & $\begin{array}{c}0.010 \\
(0.018)\end{array}$ \\
\hline 1998 & $\begin{array}{c}0.007 \\
(0.015)\end{array}$ & $\begin{array}{c}0.044^{* * * *} \\
(0.013)\end{array}$ & $\begin{array}{c}0.020 \\
(0.017)\end{array}$ \\
\hline 1999 & $\begin{array}{c}0.014 \\
(0.015)\end{array}$ & $\begin{array}{c}0.053^{* * *} \\
(0.013)\end{array}$ & $\begin{array}{l}0.028^{*} \\
(0.017)\end{array}$ \\
\hline 2000 & $\begin{array}{l}0.030^{* *} \\
(0.012)\end{array}$ & $\begin{array}{c}0.038^{* * *} \\
(0.011)\end{array}$ & $\begin{array}{l}0.024^{* *} \\
(0.011)\end{array}$ \\
\hline 2001 & $\begin{array}{l}-0.005 \\
(0.012)\end{array}$ & $\begin{array}{c}0.004 \\
(0.011)\end{array}$ & $\begin{array}{l}-0.010 \\
(0.011)\end{array}$ \\
\hline 2002 & $\begin{array}{c}0.009 \\
(0.012)\end{array}$ & $\begin{array}{c}0.017 \\
(0.011)\end{array}$ & $\begin{array}{c}0.002 \\
(0.011)\end{array}$ \\
\hline 2003 & & $\begin{array}{c}0.010 \\
(0.011)\end{array}$ & $\begin{array}{l}-0.005 \\
(0.011)\end{array}$ \\
\hline 2004 & & $\begin{array}{l}-0.016 \\
(0.010)\end{array}$ & $\begin{array}{c}-0.031^{* * *} \\
(0.010)\end{array}$ \\
\hline 2005 & & & $\begin{array}{l}-0.015 \\
(0.010)\end{array}$ \\
\hline 2006 & & & $\begin{array}{c}-0.029^{* * *} \\
(0.010)\end{array}$ \\
\hline Constant & $\begin{array}{l}0.233^{* * *} \\
(0.032)\end{array}$ & $\begin{array}{c}0.182^{* * *} \\
(0.026)\end{array}$ & $\begin{array}{l}0.191^{* * *} \\
(0.026)\end{array}$ \\
\hline Observations & 13,855 & 21,930 & 29,981 \\
\hline $\mathbf{R}^{2}$ & 0.025 & 0.015 & 0.015 \\
\hline
\end{tabular}


Appendix Table 3. VC time to investment in Early-Stage Investments with EU-ODA Given Alternative Time Periods Before/After EU-ODA. This table replicates Models (3) and (5) of Table 3 by restricting the sample to three different time periods in our analysis, 3,5 , and 7 years before and after EU-ODA. We also report here the coefficient estimates for our full set of fixed effects at the technology category and year level. In addition this table reports coefficient estimates for all our controls in the baseline specification. Standard errors are clustered at the investing firm level. ${ }^{*} \mathrm{p}<0.10 ;{ }^{* *} \mathrm{p}<0.05 ;{ }^{* * *} \mathrm{p}<0.01$.

\begin{tabular}{|c|c|c|c|c|c|c|}
\hline & \multicolumn{6}{|c|}{ Dependent variables } \\
\hline & \multicolumn{3}{|c|}{ Time to investment (days) } & \multicolumn{3}{|c|}{ Time to initial investment (days) } \\
\hline & $\begin{array}{c}3 \text { years } \\
\text { before/after } \\
(1)\end{array}$ & $\begin{array}{c}5 \text { years } \\
\text { before/after } \\
\text { (2) }\end{array}$ & $\begin{array}{c}7 \text { years } \\
\text { before/after } \\
\text { (3) }\end{array}$ & $\begin{array}{c}3 \text { years } \\
\text { before/after } \\
(4)\end{array}$ & $\begin{array}{c}5 \text { years } \\
\text { before/after } \\
\text { (5) }\end{array}$ & $\begin{array}{c}7 \text { years } \\
\text { before/after } \\
\text { (6) }\end{array}$ \\
\hline Drug-related & $\begin{array}{c}-425.747^{* * * *} \\
(62.806)\end{array}$ & $\begin{array}{c}-302.884^{* * *} \\
(52.577)\end{array}$ & $\begin{array}{c}-364.274^{* * *} \\
(49.090)\end{array}$ & $\begin{array}{c}1,378.040^{* * * *} \\
(153.970)\end{array}$ & $\begin{array}{c}-937.633^{* * *} \\
(129.447)\end{array}$ & $\begin{array}{c}-915.412^{* * *} \\
(121.481)\end{array}$ \\
\hline After ODA & $\begin{array}{c}675.209^{* * *} \\
(77.404)\end{array}$ & $\begin{array}{c}1,126.854^{* * *} \\
(67.309)\end{array}$ & $\begin{array}{c}1,608.887^{* * *} \\
(81.713)\end{array}$ & $\begin{array}{c}619.480^{* * * *} \\
(179.645)\end{array}$ & $\begin{array}{c}1,261.105^{* * * *} \\
(161.278)\end{array}$ & $\begin{array}{c}1,757.605^{* * *} \\
(212.752)\end{array}$ \\
\hline $\begin{array}{c}\text { Drug-related } \\
\text { *After ODA }\end{array}$ & $\begin{array}{c}-282.254^{* * * *} \\
(71.562)\end{array}$ & $\begin{array}{c}-466.418^{* * *} \\
(59.982)\end{array}$ & $\begin{array}{c}-618.438^{* * *} \\
(54.914)\end{array}$ & $\begin{array}{c}-83.539 \\
(162.655)\end{array}$ & $\begin{array}{c}-490.649^{* * *} \\
(141.619)\end{array}$ & $\begin{array}{c}-653.891^{* * * *} \\
(130.714)\end{array}$ \\
\hline EU startups & $\begin{array}{l}-24.096 \\
(78.986)\end{array}$ & $\begin{array}{l}-40.025 \\
(65.974)\end{array}$ & $\begin{array}{c}11.172 \\
(57.472)\end{array}$ & $\begin{array}{l}-136.523 \\
(134.323)\end{array}$ & $\begin{array}{c}-31.997 \\
(121.374)\end{array}$ & $\begin{array}{c}0.165 \\
(105.318)\end{array}$ \\
\hline US startups & $\begin{array}{c}93.766 \\
(71.602)\end{array}$ & $\begin{array}{l}-80.699 \\
(60.889)\end{array}$ & $\begin{array}{l}-86.477 \\
(52.668)\end{array}$ & $\begin{array}{c}-365.789^{* * *} \\
(123.631)\end{array}$ & $\begin{array}{c}-412.088^{* * *} \\
(112.134)\end{array}$ & $\begin{array}{c}-424.382^{* * *} \\
(96.107)\end{array}$ \\
\hline IVC & $\begin{array}{c}-269.426^{* * *} \\
(88.645)\end{array}$ & $\begin{array}{c}-216.313^{* * *} \\
(74.577)\end{array}$ & $\begin{array}{c}-219.977^{* * *} \\
(67.659)\end{array}$ & $\begin{array}{c}-630.519^{* * *} \\
(219.661)\end{array}$ & $\begin{array}{l}-302.744 \\
(195.784)\end{array}$ & $\begin{array}{l}-300.620 \\
(184.660)\end{array}$ \\
\hline CVC & $\begin{array}{l}-195.036^{*} \\
(105.175)\end{array}$ & $\begin{array}{c}-205.739^{* *} \\
(87.544)\end{array}$ & $\begin{array}{c}-196.294^{* *} \\
(78.726)\end{array}$ & $\begin{array}{c}-687.817^{* * *} \\
(251.297)\end{array}$ & $\begin{array}{l}-351.194 \\
(224.479)\end{array}$ & $\begin{array}{l}-346.014^{*} \\
(210.006)\end{array}$ \\
\hline Angel & $\begin{array}{l}-587.508^{* *} \\
(290.691)\end{array}$ & $\begin{array}{c}-687.746^{* * *} \\
(229.042)\end{array}$ & $\begin{array}{c}-845.692^{* * *} \\
(205.349)\end{array}$ & $\begin{array}{l}-612.953 \\
(467.074)\end{array}$ & $\begin{array}{l}-386.087 \\
(431.682)\end{array}$ & $\begin{array}{l}-501.253 \\
(411.769)\end{array}$ \\
\hline GVC & $\begin{array}{l}523.677^{* * *} \\
(195.011)\end{array}$ & $\begin{array}{c}260.824 \\
(166.386)\end{array}$ & $\begin{array}{l}248.004^{*} \\
(144.253)\end{array}$ & $\begin{array}{c}260.894 \\
(404.669)\end{array}$ & $\begin{array}{c}297.422 \\
(365.490)\end{array}$ & $\begin{array}{c}355.752 \\
(336.691)\end{array}$ \\
\hline Biosensors & $\begin{array}{c}- \\
1,190.555^{* * *} \\
(223.440)\end{array}$ & $\begin{array}{c}- \\
1,271.552^{* * *} \\
(156.659)\end{array}$ & $\begin{array}{c}- \\
1,462.422^{* * *} \\
(134.449)\end{array}$ & $\begin{array}{c}- \\
1,486.766^{* * *} \\
(355.829)\end{array}$ & $\begin{array}{c}-1,565.705^{* * *} \\
(319.985)\end{array}$ & $\begin{array}{c}-1,784.377^{* * *} \\
(291.707)\end{array}$ \\
\hline Biotech Equipment & $\begin{array}{c}-659.955^{* * *} \\
(86.741)\end{array}$ & $\begin{array}{c}-700.619^{* * * *} \\
(72.735)\end{array}$ & $\begin{array}{c}-776.917^{* * * *} \\
(64.720)\end{array}$ & $\begin{array}{c}- \\
1,331.983^{* * *} \\
(203.583)\end{array}$ & $\begin{array}{c}-1,217.484^{* * *} \\
(179.094)\end{array}$ & $\begin{array}{c}-1,315.571^{* * *} \\
(162.099)\end{array}$ \\
\hline Biotech Other & $\begin{array}{c}- \\
1,068.226^{* * * *} \\
(279.629)\end{array}$ & $\begin{array}{c}- \\
1,343.374^{* * * *} \\
(249.764)\end{array}$ & $\begin{array}{c}- \\
1,523.949^{* * *} \\
(244.078)\end{array}$ & $\begin{array}{c}- \\
1,742.743^{* * * *} \\
(402.753)\end{array}$ & $\begin{array}{c}-1,830.450^{* * * *} \\
(370.177)\end{array}$ & $\begin{array}{c}-1,960.427^{* * *} \\
(375.310)\end{array}$ \\
\hline
\end{tabular}




\begin{tabular}{|c|c|c|c|c|c|c|}
\hline Biotech Research & $\begin{array}{c}- \\
1,264.221^{* * * *} \\
(82.842)\end{array}$ & $\begin{array}{c}- \\
1,254.869^{* * *} \\
(69.927)\end{array}$ & $\begin{array}{c}- \\
1,311.936^{* * *} \\
(63.877)\end{array}$ & $\begin{array}{c}- \\
2,055.813^{* * * *} \\
(182.107)\end{array}$ & $\begin{array}{c}-1,825.119^{* * *} \\
(165.028)\end{array}$ & $\begin{array}{c}-1,726.026^{* * *} \\
(154.856)\end{array}$ \\
\hline Biotech-Animal & $\begin{array}{l}-995.521^{* * * *} \\
(106.775)\end{array}$ & $\begin{array}{c}-839.483^{* * *} \\
(93.886)\end{array}$ & $\begin{array}{c}-907.199^{* * *} \\
(84.623)\end{array}$ & $\begin{array}{c}- \\
1,622.910^{* * * *} \\
(227.445)\end{array}$ & $\begin{array}{c}-1,227.616^{* * * *} \\
(217.478)\end{array}$ & $\begin{array}{c}-1,449.993^{* * *} \\
(197.059)\end{array}$ \\
\hline Biotech-Industrial & $\begin{array}{l}-662.265^{* * *} \\
(131.222)\end{array}$ & $\begin{array}{c}-440.680^{* * *} \\
(106.640)\end{array}$ & $\begin{array}{c}-764.712^{* * *} \\
(85.278)\end{array}$ & $\begin{array}{c}- \\
1,516.732^{* * *} \\
(272.614)\end{array}$ & $\begin{array}{c}-807.175^{* * *} \\
(230.565)\end{array}$ & $\begin{array}{c}-1,043.802^{* * *} \\
(192.493)\end{array}$ \\
\hline Biotech-Human & $\begin{array}{c}-205.072^{* * *} \\
(37.536)\end{array}$ & $\begin{array}{c}-194.181^{* * * *} \\
(29.923)\end{array}$ & $\begin{array}{c}-228.396^{* * *} \\
(25.792)\end{array}$ & $\begin{array}{c}-423.652^{* * *} \\
(95.496)\end{array}$ & $\begin{array}{c}-453.756^{* * * *} \\
(82.301)\end{array}$ & $\begin{array}{c}-510.850^{* * *} \\
(71.273)\end{array}$ \\
\hline $\begin{array}{l}\text { Med/Health } \\
\text { Products }\end{array}$ & $\begin{array}{c}509.458^{* * *} \\
(55.682)\end{array}$ & $\begin{array}{l}608.017^{* * *} \\
(46.034)\end{array}$ & $\begin{array}{c}578.828^{* * * *} \\
(40.552)\end{array}$ & $\begin{array}{l}615.852^{* * *} \\
(135.801)\end{array}$ & $\begin{array}{l}821.750^{* * * *} \\
(116.482)\end{array}$ & $\begin{array}{l}751.838^{* * * *} \\
(99.945)\end{array}$ \\
\hline Pharmaceutical & $\begin{array}{c}-159.271^{* * *} \\
(48.390)\end{array}$ & $\begin{array}{c}-247.479^{* * *} \\
(38.145)\end{array}$ & $\begin{array}{c}-252.772^{* * *} \\
(33.432)\end{array}$ & $\begin{array}{c}-19.206 \\
(112.186)\end{array}$ & $\begin{array}{l}-25.876 \\
(97.304)\end{array}$ & $\begin{array}{l}-95.660 \\
(85.237)\end{array}$ \\
\hline 1994 & & & $\begin{array}{c}92.645 \\
(82.814)\end{array}$ & & & $\begin{array}{c}172.520 \\
(224.900)\end{array}$ \\
\hline 1995 & & & $\begin{array}{c}180.442^{* *} \\
(82.275)\end{array}$ & & & $\begin{array}{c}50.029 \\
(224.424)\end{array}$ \\
\hline 1996 & & & $\begin{array}{c}80.695 \\
(78.655)\end{array}$ & & & $\begin{array}{c}156.631 \\
(210.703)\end{array}$ \\
\hline 1997 & & $\begin{array}{c}89.082 \\
(57.505)\end{array}$ & $\begin{array}{c}212.919^{* * * *} \\
(75.473)\end{array}$ & & $\begin{array}{l}284.806^{* *} \\
(143.923)\end{array}$ & $\begin{array}{l}403.682^{* *} \\
(199.509)\end{array}$ \\
\hline 1998 & $\begin{array}{l}-90.043 \\
(60.006)\end{array}$ & $\begin{array}{c}-1.508 \\
(55.753)\end{array}$ & $\begin{array}{l}121.217 \\
(74.023)\end{array}$ & $\begin{array}{l}-123.609 \\
(139.267)\end{array}$ & $\begin{array}{c}139.682 \\
(139.136)\end{array}$ & $\begin{array}{c}261.559 \\
(194.998)\end{array}$ \\
\hline 1999 & $\begin{array}{c}42.055 \\
(59.593)\end{array}$ & $\begin{array}{c}120.179^{* *} \\
(55.188)\end{array}$ & $\begin{array}{c}244.927^{* * * *} \\
(73.490)\end{array}$ & $\begin{array}{c}145.386 \\
(139.571)\end{array}$ & $\begin{array}{l}362.988^{* * *} \\
(139.705)\end{array}$ & $\begin{array}{l}481.499^{* *} \\
(195.245)\end{array}$ \\
\hline 2000 & $\begin{array}{c}-349.795^{* * *} \\
(47.523)\end{array}$ & $\begin{array}{c}-594.514^{* * * *} \\
(45.394)\end{array}$ & $\begin{array}{c}-828.987^{* * *} \\
(45.523)\end{array}$ & $\begin{array}{c}-587.390^{* * *} \\
(117.279)\end{array}$ & $\begin{array}{c}-687.652^{* * *} \\
(120.464)\end{array}$ & $\begin{array}{c}-943.769^{* * *} \\
(115.534)\end{array}$ \\
\hline 2001 & $\begin{array}{c}-120.269^{* *} \\
(47.836)\end{array}$ & $\begin{array}{c}-359.125^{* * *} \\
(45.761)\end{array}$ & $\begin{array}{c}-594.246^{* * *} \\
(45.909)\end{array}$ & $\begin{array}{c}-414.932^{* * *} \\
(121.081)\end{array}$ & $\begin{array}{c}-533.007^{* * *} \\
(124.384)\end{array}$ & $\begin{array}{c}-800.734^{* * *} \\
(119.894)\end{array}$ \\
\hline 2002 & $\begin{array}{c}-264.022^{* * *} \\
(48.952)\end{array}$ & $\begin{array}{c}-495.211^{* * *} \\
(46.898)\end{array}$ & $\begin{array}{c}-723.912^{* * *} \\
(47.110)\end{array}$ & $\begin{array}{c}-344.840^{* * *} \\
(121.582)\end{array}$ & $\begin{array}{c}-418.476^{* * *} \\
(125.244)\end{array}$ & $\begin{array}{c}-662.633^{* * *} \\
(121.054)\end{array}$ \\
\hline 2003 & & $\begin{array}{c}-237.058^{* * * *} \\
(45.361)\end{array}$ & $\begin{array}{c}-471.369^{* * *} \\
(45.527)\end{array}$ & & $\begin{array}{c}-75.791 \\
(124.071)\end{array}$ & $\begin{array}{c}-328.448^{* * *} \\
(119.983)\end{array}$ \\
\hline 2004 & & $\begin{array}{c}-180.900^{* * *} \\
(43.023)\end{array}$ & $\begin{array}{c}-406.714^{* * *} \\
(43.193)\end{array}$ & & $\begin{array}{l}-198.330 \\
(121.770)\end{array}$ & $\begin{array}{c}-439.365^{* * *} \\
(117.455)\end{array}$ \\
\hline 2005 & & & $\begin{array}{c}-229.149^{* * *} \\
(42.304)\end{array}$ & & & $\begin{array}{l}-254.660^{* *} \\
(116.097)\end{array}$ \\
\hline 2006 & & & $-352.658^{* * * *}$ & & & $-455.131^{* * *}$ \\
\hline
\end{tabular}


(42.859)

(111.229)

\begin{tabular}{ccccccc} 
Constant & $2,274.862^{* * *}$ & $2,201.297^{* * *}$ & $2,149.136^{* * *}$ & $3,444.469^{* * *}$ & $2,511.691^{* * *}$ & $2,418.595^{* * *}$ \\
& $(128.740)$ & $(108.820)$ & $(111.363)$ & $(288.195)$ & $(255.203)$ & $(283.611)$ \\
\hline Observations & 13,855 & 21,930 & 29,981 & 3,218 & 4,752 & 6,455 \\
$\mathbf{R}^{2}$ & 0.044 & 0.052 & 0.069 & 0.096 & 0.094 & 0.109 \\
\hline
\end{tabular}


Appendix Table 4. Replication of Table 3 with Multinomial Logit Models. We report here Table 3 results with multinomial logit models, taking into account that the dependent variable is binary. Model (1) takes full samples to replicate Table 3 and Models (2), (3) and (4) replicate Appendix Table 2, restricting sample periods to 3 years, 5 years, and 7 years before and after EUODA, respectively. Results are consistent. We also report here the coefficient estimates for our full set of fixed effects at the technology category and year level. In addition this table reports coefficient estimates for all our controls in the baseline specification. Standard errors are clustered at the investing firm level. ${ }^{*} \mathrm{p}<0.10 ;{ }^{* *} \mathrm{p}<0.05 ;{ }^{* * *} \mathrm{p}<0.01$

\begin{tabular}{|c|c|c|c|c|}
\hline & \multicolumn{4}{|c|}{ Dependent variables } \\
\hline & \multicolumn{4}{|c|}{ Investment into early-stage startups (binary) } \\
\hline & $\begin{array}{c}\text { All samples } \\
\text { (1) }\end{array}$ & $\begin{array}{c}3 \text { years } \\
\text { before/after } \\
\text { (2) }\end{array}$ & $\begin{array}{c}5 \text { years } \\
\text { before/after } \\
\text { (3) }\end{array}$ & $\begin{array}{c}7 \text { years } \\
\text { before/after } \\
\text { (4) }\end{array}$ \\
\hline Drug-related & $\begin{array}{l}0.495^{* * *} \\
(0.069)\end{array}$ & $\begin{array}{c}0.700^{* * * *} \\
(0.108)\end{array}$ & $\begin{array}{c}0.467^{* * *} \\
(0.087)\end{array}$ & $\begin{array}{c}0.477^{* * * *} \\
(0.080)\end{array}$ \\
\hline After ODA & $\begin{array}{c}-0.506^{* * *} \\
(0.105)\end{array}$ & $\begin{array}{l}-0.170 \\
(0.123)\end{array}$ & $\begin{array}{l}-0.082 \\
(0.106)\end{array}$ & $\begin{array}{c}-0.290^{* *} \\
(0.123)\end{array}$ \\
\hline $\begin{array}{c}\text { Drug-related } \\
\text { *After ODA }\end{array}$ & $\begin{array}{l}0.380^{* * *} \\
(0.072)\end{array}$ & $\begin{array}{l}-0.102 \\
(0.113)\end{array}$ & $\begin{array}{l}0.055 \\
(0.093)\end{array}$ & $\begin{array}{c}0.221^{* * *} \\
(0.085)\end{array}$ \\
\hline EU startups & $\begin{array}{l}0.126^{*} \\
(0.066)\end{array}$ & $\begin{array}{l}-0.138 \\
(0.111)\end{array}$ & $\begin{array}{l}-0.133 \\
(0.093)\end{array}$ & $\begin{array}{l}-0.129 \\
(0.081)\end{array}$ \\
\hline US startups & $\begin{array}{c}0.018 \\
(0.060)\end{array}$ & $\begin{array}{c}-0.286^{* * *} \\
(0.100)\end{array}$ & $\begin{array}{c}-0.197^{* *} \\
(0.086)\end{array}$ & $\begin{array}{c}-0.187^{* *} \\
(0.074)\end{array}$ \\
\hline IVC & $\begin{array}{l}-0.127 \\
(0.082)\end{array}$ & $\begin{array}{c}-0.344^{* * *} \\
(0.119)\end{array}$ & $\begin{array}{c}-0.214^{* *} \\
(0.103)\end{array}$ & $\begin{array}{l}-0.147 \\
(0.094)\end{array}$ \\
\hline CVC & $\begin{array}{l}-0.061 \\
(0.094)\end{array}$ & $\begin{array}{l}-0.233 \\
(0.144)\end{array}$ & $\begin{array}{l}-0.093 \\
(0.122)\end{array}$ & $\begin{array}{l}-0.094 \\
(0.110)\end{array}$ \\
\hline Angel & $\begin{array}{c}0.701^{* * *} \\
(0.208)\end{array}$ & $\begin{array}{c}0.148 \\
(0.383)\end{array}$ & $\begin{array}{c}0.436 \\
(0.297)\end{array}$ & $\begin{array}{l}0.583^{* *} \\
(0.259)\end{array}$ \\
\hline GVC & $\begin{array}{c}-1.067^{* * *} \\
(0.216)\end{array}$ & $\begin{array}{c}-1.988^{* * *} \\
(0.527)\end{array}$ & $\begin{array}{c}-1.484^{* * *} \\
(0.381)\end{array}$ & $\begin{array}{c}-1.112^{* * *} \\
(0.286)\end{array}$ \\
\hline Biosensors & $\begin{array}{l}1.293^{* * * *} \\
(0.143)\end{array}$ & $\begin{array}{l}1.926^{* * *} \\
(0.284)\end{array}$ & $\begin{array}{l}1.307^{* * *} \\
(0.209)\end{array}$ & $\begin{array}{l}1.399^{* * * *} \\
(0.180)\end{array}$ \\
\hline Biotech Equipment & $\begin{array}{c}0.766^{* * * *} \\
(0.089)\end{array}$ & $\begin{array}{c}0.650^{* * *} \\
(0.143)\end{array}$ & $\begin{array}{c}0.537^{* * *} \\
(0.117)\end{array}$ & $\begin{array}{c}0.597^{* * *} \\
(0.105)\end{array}$ \\
\hline Biotech Other & $\begin{array}{c}2.210^{* * * *} \\
(0.267)\end{array}$ & $\begin{array}{c}2.265^{* * *} \\
(0.355)\end{array}$ & $\begin{array}{l}1.964^{\text {**** }} \\
(0.307)\end{array}$ & $\begin{array}{l}2.131^{* * *} \\
(0.293)\end{array}$ \\
\hline Biotech Research & $\begin{array}{l}1.042^{* * * *} \\
(0.087)\end{array}$ & $\begin{array}{c}0.964^{* * *} \\
(0.131)\end{array}$ & $\begin{array}{c}0.831^{* * *} \\
(0.108)\end{array}$ & $\begin{array}{c}0.962^{* * * *} \\
(0.099)\end{array}$ \\
\hline Biotech-Animal & $1.203^{* * *}$ & $1.618^{* * * *}$ & $1.277^{* * * *}$ & $1.286^{* * * *}$ \\
\hline
\end{tabular}




\begin{tabular}{|c|c|c|c|c|}
\hline & $(0.100)$ & $(0.149)$ & $(0.129)$ & $(0.117)$ \\
\hline Biotech-Industrial & $\begin{array}{c}0.917^{* * *} \\
(0.099)\end{array}$ & $\begin{array}{l}0.489^{* *} \\
(0.215)\end{array}$ & $\begin{array}{l}0.677^{* * *} \\
(0.161)\end{array}$ & $\begin{array}{l}0.923^{* * *} \\
(0.127)\end{array}$ \\
\hline Biotech-Human & $\begin{array}{l}0.433^{* * *} \\
(0.030)\end{array}$ & $\begin{array}{l}0.311^{* * *} \\
(0.056)\end{array}$ & $\begin{array}{l}0.248^{* * *} \\
(0.045)\end{array}$ & $\begin{array}{l}0.298^{* * *} \\
(0.038)\end{array}$ \\
\hline Med/Health Products & $\begin{array}{l}-0.043 \\
(0.050)\end{array}$ & $\begin{array}{l}-0.216^{* *} \\
(0.091)\end{array}$ & $\begin{array}{l}-0.094 \\
(0.073)\end{array}$ & $\begin{array}{l}-0.055 \\
(0.062)\end{array}$ \\
\hline Pharmaceutical & $\begin{array}{c}0.202^{* * *} \\
(0.041)\end{array}$ & $\begin{array}{l}0.328^{* * *} \\
(0.071)\end{array}$ & $\begin{array}{l}0.290^{* * *} \\
(0.056)\end{array}$ & $\begin{array}{l}0.242^{* * *} \\
(0.049)\end{array}$ \\
\hline 1990 & $\begin{array}{c}-0.324^{* * *} \\
(0.115)\end{array}$ & & & \\
\hline 1991 & $\begin{array}{c}-0.416^{* * *} \\
(0.126)\end{array}$ & & & \\
\hline 1992 & $\begin{array}{c}-0.634^{* * *} \\
(0.115)\end{array}$ & & & \\
\hline 1993 & $\begin{array}{c}-0.470^{* * *} \\
(0.116)\end{array}$ & & & \\
\hline 1994 & $\begin{array}{c}-0.661^{* * *} \\
(0.115)\end{array}$ & & & $\begin{array}{l}-0.184 \\
(0.123)\end{array}$ \\
\hline 1995 & $\begin{array}{c}-0.508^{* * *} \\
(0.112)\end{array}$ & & & $\begin{array}{l}-0.046 \\
(0.121)\end{array}$ \\
\hline 1996 & $\begin{array}{c}-0.730^{* * *} \\
(0.110)\end{array}$ & & & $\begin{array}{l}-0.266^{* *} \\
(0.119)\end{array}$ \\
\hline 1997 & $\begin{array}{c}-0.393^{* * *} \\
(0.100)\end{array}$ & & $\begin{array}{l}0.223^{* *} \\
(0.087)\end{array}$ & $\begin{array}{c}0.060 \\
(0.110)\end{array}$ \\
\hline 1998 & $\begin{array}{c}-0.342^{* * *} \\
(0.097)\end{array}$ & $\begin{array}{c}0.041 \\
(0.090)\end{array}$ & $\begin{array}{l}0.276^{* * *} \\
(0.084)\end{array}$ & $\begin{array}{c}0.115 \\
(0.107)\end{array}$ \\
\hline 1999 & $\begin{array}{c}-0.298^{* * *} \\
(0.096)\end{array}$ & $\begin{array}{c}0.080 \\
(0.088)\end{array}$ & $\begin{array}{l}0.321^{* * *} \\
(0.082)\end{array}$ & $\begin{array}{c}0.159 \\
(0.106)\end{array}$ \\
\hline 2000 & $\begin{array}{c}-0.236^{* * *} \\
(0.065)\end{array}$ & $\begin{array}{l}0.178^{* *} \\
(0.071)\end{array}$ & $\begin{array}{l}0.231^{* * *} \\
(0.067)\end{array}$ & $\begin{array}{l}0.140^{* * *} \\
(0.065)\end{array}$ \\
\hline 2001 & $\begin{array}{c}-0.441^{* * *} \\
(0.068)\end{array}$ & $\begin{array}{l}-0.031 \\
(0.074)\end{array}$ & $\begin{array}{c}0.025 \\
(0.070)\end{array}$ & $\begin{array}{l}-0.064 \\
(0.068)\end{array}$ \\
\hline 2002 & $\begin{array}{c}-0.368^{* * *} \\
(0.069)\end{array}$ & $\begin{array}{c}0.055 \\
(0.075)\end{array}$ & $\begin{array}{c}0.105 \\
(0.071)\end{array}$ & $\begin{array}{c}0.013 \\
(0.069)\end{array}$ \\
\hline 2003 & $\begin{array}{c}-0.410^{* * * *} \\
(0.067)\end{array}$ & & $\begin{array}{c}0.061 \\
(0.069)\end{array}$ & $\begin{array}{l}-0.029 \\
(0.067)\end{array}$ \\
\hline 2004 & $\begin{array}{c}-0.595^{* * *} \\
(0.065)\end{array}$ & & $\begin{array}{l}-0.107 \\
(0.067)\end{array}$ & $\begin{array}{c}-0.202^{* * *} \\
(0.065)\end{array}$ \\
\hline 2005 & $-0.484^{* * *}$ & & & -0.095 \\
\hline
\end{tabular}




\begin{tabular}{|c|c|c|c|c|}
\hline & $(0.063)$ & & & $(0.063)$ \\
\hline \multirow[t]{2}{*}{2006} & $-0.571^{* * *}$ & & & $-0.193^{* * *}$ \\
\hline & $(0.065)$ & & & $(0.065)$ \\
\hline \multirow[t]{2}{*}{2007} & $-0.381^{* * *}$ & & & \\
\hline & $(0.060)$ & & & \\
\hline \multirow[t]{2}{*}{2008} & $-0.295^{* * *}$ & & & \\
\hline & $(0.060)$ & & & \\
\hline \multirow[t]{2}{*}{2009} & $-0.152^{* *}$ & & & \\
\hline & $(0.063)$ & & & \\
\hline \multirow[t]{2}{*}{2010} & $-0.272^{* * *}$ & & & \\
\hline & $(0.061)$ & & & \\
\hline \multirow[t]{2}{*}{ Constant } & $-1.407^{* * *}$ & $-1.406^{* * * *}$ & $-1.636^{* * * *}$ & $-1.578^{* * *}$ \\
\hline & $(0.138)$ & $(0.188)$ & $(0.160)$ & $(0.163)$ \\
\hline Observations & 44,867 & 13,855 & 21,930 & 29,981 \\
\hline Log Likelihood & $-22,729.940$ & $-7,046.800$ & $-10,929.760$ & $-14,805.760$ \\
\hline
\end{tabular}


Appendix Table 5. Replication of Table 3 with Alternative Definitions of the Treatment Group. We report here Table 3 results using alternative definitions of the treatment group. In Panel 1, we include Biotech Research and Biotech Other in the treatment group instead of the control group. In Panel 2, we switch Medical Diagnostics from the treatment group to the control group. Results across all the robustness checks remain consistent. We also report here the coefficient estimates for our full set of fixed effects at the technology category and year level. In addition this table reports coefficient estimates for all our controls in the baseline specification. Standard errors are clustered at the investing firm level. ${ }^{*} \mathrm{p}<0.10 ;{ }^{* *} \mathrm{p}<0.05 ;{ }^{* * *} \mathrm{p}<0.01$

\section{Appendix Table 5 Panel 1. Table 3 with inclusion of Biotech Research and Biotech Other in the treatment group}

\begin{tabular}{|c|c|c|c|c|c|c|}
\hline & \multicolumn{6}{|c|}{ Dependent variables } \\
\hline & \multicolumn{2}{|c|}{ Early-stage } & \multicolumn{2}{|c|}{ Time to investment } & \multicolumn{2}{|c|}{ Time to initial investment } \\
\hline & $\begin{array}{c}O L S \\
(1)\end{array}$ & $\begin{array}{c}\text { Fixed effect } \\
\text { (2) }\end{array}$ & $\begin{array}{l}O L S \\
(3)\end{array}$ & $\begin{array}{c}\text { Fixed effect } \\
\text { (4) }\end{array}$ & $\begin{array}{c}O L S \\
(5)\end{array}$ & $\begin{array}{c}\text { Fixed effect } \\
\text { (6) }\end{array}$ \\
\hline Drug-related & $\begin{array}{c}0.056^{* * *} \\
(0.014)\end{array}$ & $\begin{array}{c}0.008 \\
(0.016)\end{array}$ & $\begin{array}{c}-312.779^{* * *} \\
(84.273)\end{array}$ & $\begin{array}{c}17.326 \\
(99.479)\end{array}$ & $\begin{array}{c}-778.783^{* * *} \\
(124.670)\end{array}$ & $\begin{array}{l}-178.912 \\
(166.441)\end{array}$ \\
\hline After ODA & $\begin{array}{c}-0.075^{\text {*** }} \\
(0.022)\end{array}$ & $\begin{array}{c}-0.116^{* * * *} \\
(0.025)\end{array}$ & $\begin{array}{c}2,293.556^{* * *} \\
(113.563)\end{array}$ & $\begin{array}{c}2,274.519^{* * *} \\
(141.355)\end{array}$ & $\begin{array}{c}2,509.393^{* * *} \\
(219.370)\end{array}$ & $\begin{array}{c}1,691.773^{* * *} \\
(308.793)\end{array}$ \\
\hline $\begin{array}{c}\text { Drug-related } \\
\text { *After ODA }\end{array}$ & $\begin{array}{l}0.053^{\text {*** }} \\
(0.016)\end{array}$ & $\begin{array}{l}0.037^{*} \\
(0.020)\end{array}$ & $\begin{array}{c}-757.265^{* * *} \\
(99.653)\end{array}$ & $\begin{array}{c}-402.161^{* * *} \\
(105.921)\end{array}$ & $\begin{array}{c}-793.751^{* * *} \\
(144.949)\end{array}$ & $\begin{array}{l}-406.200^{* *} \\
(183.928)\end{array}$ \\
\hline EU startups & $\begin{array}{c}0.020 \\
(0.017)\end{array}$ & $\begin{array}{l}0.059^{* *} \\
(0.024)\end{array}$ & $\begin{array}{l}-149.545 \\
(106.558)\end{array}$ & $\begin{array}{c}-597.611^{* * *} \\
(119.747)\end{array}$ & $\begin{array}{l}-160.572 \\
(127.460)\end{array}$ & $\begin{array}{c}-754.347^{* * *} \\
(235.583)\end{array}$ \\
\hline US startups & $\begin{array}{c}0.002 \\
(0.015)\end{array}$ & $\begin{array}{c}0.017 \\
(0.021)\end{array}$ & $\begin{array}{l}-271.828^{* *} \\
(105.962)\end{array}$ & $\begin{array}{c}-406.244^{* * *} \\
(125.473)\end{array}$ & $\begin{array}{c}-536.238^{* * *} \\
(119.834)\end{array}$ & $\begin{array}{l}-626.126^{* * *} \\
(211.862)\end{array}$ \\
\hline Biosensors & $\begin{array}{l}0.183^{* * *} \\
(0.030)\end{array}$ & $\begin{array}{l}0.092^{* * *} \\
(0.032)\end{array}$ & $\begin{array}{c}-1,536.988^{* * *} \\
(144.341)\end{array}$ & $\begin{array}{c}-736.811^{* * *} \\
(164.369)\end{array}$ & $\begin{array}{c}-1,861.929^{* * *} \\
(194.609)\end{array}$ & $\begin{array}{l}-523.126^{* *} \\
(253.857)\end{array}$ \\
\hline Biotech Equipment & $\begin{array}{l}0.094^{* * *} \\
(0.016)\end{array}$ & $\begin{array}{c}0.016 \\
(0.019)\end{array}$ & $\begin{array}{c}-894.173^{* * *} \\
(110.776)\end{array}$ & $\begin{array}{l}-262.330^{* *} \\
(122.455)\end{array}$ & $\begin{array}{c}-1,346.132^{* * *} \\
(179.273)\end{array}$ & $\begin{array}{l}-163.319 \\
(218.993)\end{array}$ \\
\hline Biotech Other & $\begin{array}{l}0.307^{* * *} \\
(0.075)\end{array}$ & $\begin{array}{l}0.227^{* * *} \\
(0.072)\end{array}$ & $\begin{array}{c}-770.754^{* * *} \\
(269.496)\end{array}$ & $\begin{array}{l}-359.044 \\
(317.404)\end{array}$ & $\begin{array}{l}-511.330^{* *} \\
(228.531)\end{array}$ & $\begin{array}{c}72.284 \\
(281.505)\end{array}$ \\
\hline Biotech Research & $\begin{array}{l}0.037^{* *} \\
(0.018)\end{array}$ & $\begin{array}{c}0.030 \\
(0.018)\end{array}$ & $\begin{array}{c}-348.893^{* * *} \\
(69.850)\end{array}$ & $\begin{array}{c}-354.192^{* * *} \\
(74.405)\end{array}$ & $\begin{array}{l}-202.670 \\
(126.759)\end{array}$ & $\begin{array}{l}-273.503^{*} \\
(143.721)\end{array}$ \\
\hline Biotech-Animal & $\begin{array}{l}0.175^{\text {*** }} \\
(0.026)\end{array}$ & $\begin{array}{l}0.107^{* * *} \\
(0.031)\end{array}$ & $\begin{array}{l}-875.844^{* * *} \\
(124.130)\end{array}$ & $\begin{array}{c}-450.302^{* * *} \\
(154.513)\end{array}$ & $\begin{array}{c}-1,460.956^{* * *} \\
(187.701)\end{array}$ & $\begin{array}{l}-873.056^{* * *} \\
(266.431)\end{array}$ \\
\hline Biotech-Industrial & $\begin{array}{l}0.116^{* * *} \\
(0.019)\end{array}$ & $\begin{array}{c}0.027 \\
(0.022)\end{array}$ & $\begin{array}{c}-991.489^{* * *} \\
(151.421)\end{array}$ & $\begin{array}{l}-272.467^{*} \\
(156.720)\end{array}$ & $\begin{array}{c}-1,203.981^{\text {*** }} \\
(207.346)\end{array}$ & $\begin{array}{c}-77.704 \\
(264.946)\end{array}$ \\
\hline Biotech-Human & $\begin{array}{l}0.075^{* * *} \\
(0.009)\end{array}$ & $\begin{array}{l}0.059^{* * *} \\
(0.011)\end{array}$ & $\begin{array}{c}-303.115^{* * *} \\
(42.151)\end{array}$ & $\begin{array}{c}-214.179^{* * *} \\
(40.910)\end{array}$ & $\begin{array}{c}-620.449^{* * *} \\
(56.208)\end{array}$ & $\begin{array}{c}-235.230^{* * *} \\
(62.376)\end{array}$ \\
\hline Med/Health Products & -0.007 & -0.005 & $510.376^{* * *}$ & $439.617^{* * *}$ & $863.342^{* * *}$ & $737.870^{* * *}$ \\
\hline
\end{tabular}




\begin{tabular}{|c|c|c|c|c|c|c|}
\hline & $(0.009)$ & $(0.010)$ & (75.145) & (68.739) & (127.409) & (148.626) \\
\hline Pharmaceutical & $\begin{array}{l}0.032^{* * * *} \\
(0.010)\end{array}$ & $\begin{array}{l}0.036^{* * *} \\
(0.010)\end{array}$ & $\begin{array}{c}-239.404^{* * *} \\
(55.149)\end{array}$ & $\begin{array}{c}-309.262^{* * * *} \\
(53.848)\end{array}$ & & \\
\hline 1990 & $\begin{array}{l}-0.061^{* *} \\
(0.027)\end{array}$ & $\begin{array}{l}-0.062^{* *} \\
(0.031)\end{array}$ & $\begin{array}{c}239.449^{* * *} \\
(72.575)\end{array}$ & $\begin{array}{c}297.801^{* * * *} \\
(72.985)\end{array}$ & $\begin{array}{c}-44.882 \\
(188.928)\end{array}$ & $\begin{array}{c}181.508 \\
(238.956)\end{array}$ \\
\hline 1991 & $\begin{array}{c}-0.075^{* * * *} \\
(0.025)\end{array}$ & $\begin{array}{l}-0.071^{* *} \\
(0.028)\end{array}$ & $\begin{array}{c}385.126^{* * *} \\
(76.545)\end{array}$ & $\begin{array}{c}475.695^{* * *} \\
(76.851)\end{array}$ & $\begin{array}{c}78.772 \\
(190.482)\end{array}$ & $\begin{array}{c}88.367 \\
(224.250)\end{array}$ \\
\hline 1992 & $\begin{array}{c}-0.113^{* * *} \\
(0.023)\end{array}$ & $\begin{array}{c}-0.112^{* * * *} \\
(0.025)\end{array}$ & $\begin{array}{c}281.881^{* * *} \\
(62.470)\end{array}$ & $\begin{array}{c}316.225^{* * *} \\
(67.524)\end{array}$ & $\begin{array}{l}424.714^{* *} \\
(174.903)\end{array}$ & $\begin{array}{c}255.043 \\
(226.023)\end{array}$ \\
\hline 1993 & $\begin{array}{c}-0.086^{* * *} \\
(0.023)\end{array}$ & $\begin{array}{c}-0.089^{* * * *} \\
(0.026)\end{array}$ & $\begin{array}{c}159.773^{* *} \\
(80.793)\end{array}$ & $\begin{array}{c}226.022^{* * *} \\
(82.394)\end{array}$ & $\begin{array}{c}143.177 \\
(173.955)\end{array}$ & $\begin{array}{c}341.900 \\
(218.602)\end{array}$ \\
\hline 1994 & $\begin{array}{c}-0.115^{* * *} \\
(0.023)\end{array}$ & $\begin{array}{c}-0.122^{* * *} \\
(0.026)\end{array}$ & $\begin{array}{c}254.024^{* * *} \\
(69.796)\end{array}$ & $\begin{array}{c}320.476^{* * *} \\
(79.753)\end{array}$ & $\begin{array}{l}334.391^{* *} \\
(163.161)\end{array}$ & $\begin{array}{c}321.836 \\
(205.295)\end{array}$ \\
\hline 1995 & $\begin{array}{c}-0.090^{* * *} \\
(0.027)\end{array}$ & $\begin{array}{c}-0.107^{* * *} \\
(0.030)\end{array}$ & $\begin{array}{c}333.065^{* * *} \\
(81.727)\end{array}$ & $\begin{array}{c}416.275^{* * *} \\
(93.985)\end{array}$ & $\begin{array}{c}210.492 \\
(172.255)\end{array}$ & $\begin{array}{c}167.576 \\
(225.928)\end{array}$ \\
\hline 1996 & $\begin{array}{c}-0.122^{* * *} \\
(0.021)\end{array}$ & $\begin{array}{c}-0.140^{* * *} \\
(0.024)\end{array}$ & $\begin{array}{c}225.681^{* * *} \\
(78.902)\end{array}$ & $\begin{array}{c}299.215^{* * *} \\
(94.639)\end{array}$ & $\begin{array}{c}282.797 \\
(183.840)\end{array}$ & $\begin{array}{c}292.208 \\
(245.026)\end{array}$ \\
\hline 1997 & $\begin{array}{c}-0.071^{* * *} \\
(0.020)\end{array}$ & $\begin{array}{c}-0.080^{* * * *} \\
(0.023)\end{array}$ & $\begin{array}{c}360.057^{* * *} \\
(73.827)\end{array}$ & $\begin{array}{c}378.490^{* * *} \\
(94.966)\end{array}$ & $\begin{array}{l}553.665^{* * *} \\
(161.489)\end{array}$ & $\begin{array}{c}243.451 \\
(202.059)\end{array}$ \\
\hline 1998 & $\begin{array}{c}-0.062^{* * *} \\
(0.023)\end{array}$ & $\begin{array}{c}-0.082^{* * * *} \\
(0.026)\end{array}$ & $\begin{array}{c}269.721^{* * * *} \\
(79.394)\end{array}$ & $\begin{array}{c}329.730^{* * *} \\
(90.948)\end{array}$ & $\begin{array}{l}416.988^{* * *} \\
(140.065)\end{array}$ & $\begin{array}{l}397.139^{* *} \\
(181.322)\end{array}$ \\
\hline 1999 & $\begin{array}{c}-0.053^{* *} \\
(0.021)\end{array}$ & $\begin{array}{c}-0.070^{* * *} \\
(0.025)\end{array}$ & $\begin{array}{c}382.071^{* * * *} \\
(81.875)\end{array}$ & $\begin{array}{l}442.144^{* * *} \\
(104.257)\end{array}$ & $\begin{array}{l}610.234^{* * *} \\
(181.512)\end{array}$ & $\begin{array}{l}630.942^{* * *} \\
(241.640)\end{array}$ \\
\hline 2000 & $\begin{array}{c}-0.043^{* *} \\
(0.018)\end{array}$ & $\begin{array}{l}-0.017 \\
(0.021)\end{array}$ & $\begin{array}{c}-1,244.071^{* * *} \\
(68.490)\end{array}$ & $\begin{array}{c}-1,465.666^{* * *} \\
(79.789)\end{array}$ & $\begin{array}{c}-1,426.823^{* * * *} \\
(166.956)\end{array}$ & $\begin{array}{c}-919.971^{\text {**** }} \\
(233.906)\end{array}$ \\
\hline 2001 & $\begin{array}{c}-0.077^{* * *} \\
(0.017)\end{array}$ & $\begin{array}{l}-0.047^{* *} \\
(0.020)\end{array}$ & $\begin{array}{c}-1,011.084^{* * * *} \\
(70.668)\end{array}$ & $\begin{array}{c}-1,212.168^{* * * *} \\
(77.645)\end{array}$ & $\begin{array}{c}-1,267.954^{* * * *} \\
(163.839)\end{array}$ & $\begin{array}{c}-748.941^{\text {**** }} \\
(218.419)\end{array}$ \\
\hline 2002 & $\begin{array}{c}-0.065^{* * *} \\
(0.016)\end{array}$ & $\begin{array}{l}-0.033^{*} \\
(0.018)\end{array}$ & $\begin{array}{c}-1,135.153^{* * *} \\
(64.856)\end{array}$ & $\begin{array}{c}-1,347.862^{* * *} \\
(71.776)\end{array}$ & $\begin{array}{c}-1,142.195^{* * *} \\
(172.779)\end{array}$ & $\begin{array}{c}-878.434^{* * * *} \\
(228.860)\end{array}$ \\
\hline 2003 & $\begin{array}{c}-0.072^{* * *} \\
(0.016)\end{array}$ & $\begin{array}{l}-0.047^{* *} \\
(0.018)\end{array}$ & $\begin{array}{c}-886.222^{* * *} \\
(64.461)\end{array}$ & $\begin{array}{c}-1,048.614^{* * *} \\
(66.795)\end{array}$ & $\begin{array}{c}-815.153^{* * *} \\
(190.000)\end{array}$ & $\begin{array}{l}-381.346 \\
(234.444)\end{array}$ \\
\hline 2004 & $\begin{array}{c}-0.100^{* * *} \\
(0.014)\end{array}$ & $\begin{array}{c}-0.072^{* * *} \\
(0.016)\end{array}$ & $\begin{array}{c}-819.154^{* * *} \\
(61.903)\end{array}$ & $\begin{array}{c}-990.645^{* * *} \\
(62.193)\end{array}$ & $\begin{array}{c}-915.231^{* * *} \\
(174.689)\end{array}$ & $\begin{array}{c}-645.245^{* * *} \\
(214.857)\end{array}$ \\
\hline 2005 & $\begin{array}{c}-0.084^{* * *} \\
(0.015)\end{array}$ & $\begin{array}{c}-0.055^{* * *} \\
(0.015)\end{array}$ & $\begin{array}{c}-642.311^{* * * *} \\
(70.014)\end{array}$ & $\begin{array}{c}-772.700^{* * *} \\
(67.602)\end{array}$ & $\begin{array}{c}-736.124^{* * *} \\
(191.750)\end{array}$ & $\begin{array}{l}-406.217^{*} \\
(233.986)\end{array}$ \\
\hline 2006 & $\begin{array}{c}-0.097^{* * *} \\
(0.014)\end{array}$ & $\begin{array}{c}-0.077^{* * *} \\
(0.015)\end{array}$ & $\begin{array}{c}-765.002^{* * *} \\
(58.857)\end{array}$ & $\begin{array}{c}-864.378^{* * *} \\
(57.225)\end{array}$ & $\begin{array}{c}-944.512^{* * *} \\
(171.303)\end{array}$ & $\begin{array}{c}-610.897^{* * * *} \\
(217.582)\end{array}$ \\
\hline 2007 & $\begin{array}{c}-0.067^{* * *} \\
(0.012)\end{array}$ & $\begin{array}{c}-0.049^{* * *} \\
(0.013)\end{array}$ & $\begin{array}{c}-413.704^{* * *} \\
(61.778)\end{array}$ & $\begin{array}{c}-543.976^{* * *} \\
(59.247)\end{array}$ & $\begin{array}{c}-489.795^{* * * *} \\
(176.854)\end{array}$ & $\begin{array}{l}-179.271 \\
(211.614)\end{array}$ \\
\hline 2008 & $-0.053^{* * *}$ & $-0.044^{* * * *}$ & $-377.526^{* * *}$ & $-474.712^{* * * *}$ & $-516.732^{* * *}$ & -163.069 \\
\hline
\end{tabular}




\begin{tabular}{ccccccc} 
& $(0.012)$ & $(0.013)$ & $(64.615)$ & $(59.484)$ & $(174.014)$ & $(201.457)$ \\
$\mathbf{2 0 0 9}$ & $-0.028^{* * *}$ & -0.021 & $-253.939^{* * *}$ & $-290.822^{* * *}$ & $-592.561^{* * *}$ & $-366.605^{*}$ \\
& $(0.014)$ & $(0.014)$ & $(63.201)$ & $(59.559)$ & $(189.035)$ & $(219.854)$ \\
\multirow{2}{2010}{} & $-0.050^{* * *}$ & $-0.042^{* * *}$ & -58.005 & $-95.280^{*}$ & -116.299 & 105.633 \\
& $(0.011)$ & $(0.012)$ & $(57.365)$ & $(53.558)$ & $(196.637)$ & $(225.678)$ \\
\multirow{2}{*}{ Constant } & $0.210^{* * * *}$ & & $1,949.102^{* * *}$ & & $1,983.853^{* * *}$ & \\
& $(0.025)$ & & $(135.244)$ & & $(201.433)$ & \\
\hline Observations & 44,867 & 44,867 & 44,867 & 44,867 & 8,933 & 8,933 \\
$\mathbf{R}^{2}$ & 0.020 & 0.131 & 0.100 & 0.363 & 0.135 & 0.548 \\
\hline
\end{tabular}


Appendix Table 5 Panel 2. Table 3 results with Medical Diagnostics in the control group

\begin{tabular}{|c|c|c|c|c|c|c|}
\hline & \multicolumn{6}{|c|}{ Dependent variable: } \\
\hline & \multicolumn{2}{|c|}{ Early-stage } & \multicolumn{2}{|c|}{ Time to investment } & \multicolumn{2}{|c|}{ Time to initial investment } \\
\hline & (1) & (2) & (3) & (4) & (5) & (6) \\
\hline Drug-related & $\begin{array}{l}0.042^{* * *} \\
(0.013)\end{array}$ & $\begin{array}{c}0.015 \\
(0.017)\end{array}$ & $\begin{array}{c}-340.777^{* * *} \\
(62.548)\end{array}$ & $\begin{array}{c}-125.661^{*} \\
(76.046)\end{array}$ & $\begin{array}{c}-614.126^{* * *} \\
(99.115)\end{array}$ & $\begin{array}{l}-139.309 \\
(129.097)\end{array}$ \\
\hline After ODA & $\begin{array}{c}-0.065^{* * *} \\
(0.020)\end{array}$ & $\begin{array}{l}-0.117^{* * *} \\
(0.023)\end{array}$ & $\begin{array}{c}2,050.084^{* * *} \\
(88.317)\end{array}$ & $\begin{array}{c}2,159.881^{* * * *} \\
(128.323)\end{array}$ & $\begin{array}{c}2,310.335^{* * *} \\
(203.832)\end{array}$ & $\begin{array}{c}1,463.176^{* * *} \\
(280.869)\end{array}$ \\
\hline $\begin{array}{c}\text { Drug-related } \\
* \text { After ODA }\end{array}$ & $0.042^{* * *}$ & $0.039^{* *}$ & $-473.260^{* * *}$ & $-267.004^{* * *}$ & $-418.754^{* * *}$ & -99.110 \\
\hline & $(0.015)$ & $(0.018)$ & (75.367) & $(86.862)$ & (119.833) & (146.340) \\
\hline EU startups & $\begin{array}{c}0.016 \\
(0.017)\end{array}$ & $\begin{array}{l}0.054^{* *} \\
(0.023)\end{array}$ & $\begin{array}{l}-109.155 \\
(107.039)\end{array}$ & $\begin{array}{c}-567.904^{* * *} \\
(117.722)\end{array}$ & $\begin{array}{l}-106.654 \\
(130.727)\end{array}$ & $\begin{array}{l}-748.148^{* * *} \\
(237.537)\end{array}$ \\
\hline US startups & $\begin{array}{l}-0.003 \\
(0.015)\end{array}$ & $\begin{array}{c}0.013 \\
(0.021)\end{array}$ & $\begin{array}{l}-225.133^{* *} \\
(105.900)\end{array}$ & $\begin{array}{c}-375.243^{* * *} \\
(124.559)\end{array}$ & $\begin{array}{c}-465.422^{* * *} \\
(121.366)\end{array}$ & $\begin{array}{c}-613.098^{* * *} \\
(213.561)\end{array}$ \\
\hline Biosensors & $\begin{array}{l}0.148^{* * *} \\
(0.029)\end{array}$ & $\begin{array}{l}0.090^{* * *} \\
(0.031)\end{array}$ & $\begin{array}{c}-1,199.475^{* * *} \\
(119.061)\end{array}$ & $\begin{array}{c}-677.089^{* * *} \\
(131.728)\end{array}$ & $\begin{array}{c}-1,319.412^{* * *} \\
(177.528)\end{array}$ & $\begin{array}{l}-199.567 \\
(216.010)\end{array}$ \\
\hline Biotech Equipment & $\begin{array}{l}0.063^{* * *} \\
(0.015)\end{array}$ & $\begin{array}{c}0.014 \\
(0.017)\end{array}$ & $\begin{array}{c}-611.033^{* * *} \\
(81.543)\end{array}$ & $\begin{array}{c}-227.102^{* * *} \\
(84.891)\end{array}$ & $\begin{array}{c}-876.287^{* * *} \\
(163.053)\end{array}$ & $\begin{array}{c}90.527 \\
(189.521)\end{array}$ \\
\hline Biotech Other & $\begin{array}{l}0.367^{* * *} \\
(0.077)\end{array}$ & $\begin{array}{l}0.260^{* * *} \\
(0.074)\end{array}$ & $\begin{array}{c}-1,336.215^{* * *} \\
(292.791)\end{array}$ & $\begin{array}{l}-596.631^{*} \\
(330.905)\end{array}$ & $\begin{array}{c}-1,355.097^{* * *} \\
(251.760)\end{array}$ & $\begin{array}{l}-137.702 \\
(296.375)\end{array}$ \\
\hline Biotech Research & $\begin{array}{l}0.104^{* * *} \\
(0.019)\end{array}$ & $\begin{array}{l}0.066^{* * *} \\
(0.019)\end{array}$ & $\begin{array}{c}-985.208^{* * * *} \\
(80.771)\end{array}$ & $\begin{array}{c}-620.506^{* * *} \\
(88.815)\end{array}$ & $\begin{array}{c}-1,108.393^{* * *} \\
(140.931)\end{array}$ & $\begin{array}{c}-492.335^{* * *} \\
(162.858)\end{array}$ \\
\hline Biotech-Animal & $\begin{array}{l}0.143^{* * *} \\
(0.025)\end{array}$ & $\begin{array}{l}0.105^{* * *} \\
(0.029)\end{array}$ & $\begin{array}{c}-612.302^{* * * *} \\
(99.863)\end{array}$ & $\begin{array}{c}-425.261^{* * *} \\
(120.502)\end{array}$ & $\begin{array}{c}-1,000.530^{* * * *} \\
(171.358)\end{array}$ & $\begin{array}{c}-625.889^{* * * *} \\
(232.400)\end{array}$ \\
\hline Biotech-Industrial & $\begin{array}{l}0.083^{* * *} \\
(0.018)\end{array}$ & $\begin{array}{c}0.025 \\
(0.020)\end{array}$ & $\begin{array}{c}-667.111^{* * *} \\
(130.471)\end{array}$ & $\begin{array}{l}-221.800^{*} \\
(127.649)\end{array}$ & $\begin{array}{c}-671.452^{* * *} \\
(193.222)\end{array}$ & $\begin{array}{c}204.700 \\
(232.490)\end{array}$ \\
\hline Biotech-Human & $\begin{array}{l}0.065^{* * *} \\
(0.010)\end{array}$ & $\begin{array}{c}0.048^{* * *} \\
(0.012)\end{array}$ & $\begin{array}{c}-196.342^{* * *} \\
(47.117)\end{array}$ & $\begin{array}{c}-133.441^{* * *} \\
(45.486)\end{array}$ & $\begin{array}{c}-578.633^{* * *} \\
(60.377)\end{array}$ & $\begin{array}{c}-231.471^{* * * *} \\
(62.104)\end{array}$ \\
\hline Med/Health Products & $\begin{array}{l}-0.018^{*} \\
(0.010)\end{array}$ & $\begin{array}{l}-0.016 \\
(0.011)\end{array}$ & $\begin{array}{c}618.441^{* * *} \\
(77.430)\end{array}$ & $\begin{array}{c}516.409^{* * *} \\
(71.101)\end{array}$ & $\begin{array}{c}907.257^{* * *} \\
(128.863)\end{array}$ & $\begin{array}{l}728.995^{* * *} \\
(148.116)\end{array}$ \\
\hline Pharmaceutical & $\begin{array}{l}0.022^{* *} \\
(0.010)\end{array}$ & $\begin{array}{l}0.024^{* *} \\
(0.011)\end{array}$ & $\begin{array}{c}-131.126^{* *} \\
(58.625)\end{array}$ & $\begin{array}{c}-228.570^{* * *} \\
(57.867)\end{array}$ & & \\
\hline 1990 & $\begin{array}{l}-0.061^{* *} \\
(0.027)\end{array}$ & $\begin{array}{l}-0.062^{* *} \\
(0.031)\end{array}$ & $\begin{array}{c}244.627^{* * *} \\
(72.109)\end{array}$ & $\begin{array}{c}303.087^{* * *} \\
(72.873)\end{array}$ & $\begin{array}{c}20.816 \\
(191.659)\end{array}$ & $\begin{array}{c}191.893 \\
(238.740)\end{array}$ \\
\hline 1991 & $\begin{array}{c}-0.074^{* * *} \\
(0.025)\end{array}$ & $\begin{array}{l}-0.071^{* *} \\
(0.028)\end{array}$ & $\begin{array}{c}387.360^{* * *} \\
(75.924)\end{array}$ & $\begin{array}{c}483.632^{* * * *} \\
(76.861)\end{array}$ & $\begin{array}{c}113.779 \\
(188.456)\end{array}$ & $\begin{array}{c}112.297 \\
(223.090)\end{array}$ \\
\hline 1992 & $\begin{array}{c}-0.112^{* * * *} \\
(0.023)\end{array}$ & $\begin{array}{c}-0.111^{* * *} \\
(0.025)\end{array}$ & $\begin{array}{c}283.719^{* * *} \\
(61.525)\end{array}$ & $\begin{array}{c}320.771^{* * * *} \\
(67.857)\end{array}$ & $\begin{array}{l}521.940^{* * * *} \\
(172.286)\end{array}$ & $\begin{array}{c}287.189 \\
(223.176)\end{array}$ \\
\hline 1993 & $-0.086^{* * *}$ & $-0.089^{* * *}$ & $174.989^{* *}$ & $235.085^{* * *}$ & 221.716 & $365.212^{*}$ \\
\hline
\end{tabular}




\begin{tabular}{|c|c|c|c|c|c|c|}
\hline & $(0.023)$ & $(0.026)$ & (79.563) & $(82.479)$ & $(175.990)$ & $(215.278)$ \\
\hline 1994 & $\begin{array}{c}-0.115^{\text {*** }} \\
(0.023)\end{array}$ & $\begin{array}{l}-0.122^{* * *} \\
(0.026)\end{array}$ & $\begin{array}{c}265.532^{* * * *} \\
(68.983)\end{array}$ & $\begin{array}{c}328.455^{* * *} \\
(79.325)\end{array}$ & $\begin{array}{l}393.571^{\text {** }} \\
(162.935)\end{array}$ & $\begin{array}{c}335.397 \\
(208.205)\end{array}$ \\
\hline 1995 & $\begin{array}{c}-0.090^{* * *} \\
(0.027)\end{array}$ & $\begin{array}{l}-0.107^{* * *} \\
(0.030)\end{array}$ & $\begin{array}{c}345.382^{* * *} \\
(80.155)\end{array}$ & $\begin{array}{c}424.029^{* * *} \\
(94.239)\end{array}$ & $\begin{array}{l}315.931^{*} \\
(168.629)\end{array}$ & $\begin{array}{c}199.536 \\
(220.986)\end{array}$ \\
\hline 1996 & $\begin{array}{c}-0.125^{\text {*** }} \\
(0.021)\end{array}$ & $\begin{array}{l}-0.141^{* * *} \\
(0.024)\end{array}$ & $\begin{array}{c}250.309^{* * * *} \\
(77.691)\end{array}$ & $\begin{array}{c}302.230^{* * *} \\
(94.984)\end{array}$ & $\begin{array}{l}385.265^{* *} \\
(186.850)\end{array}$ & $\begin{array}{c}308.963 \\
(241.198)\end{array}$ \\
\hline 1997 & $\begin{array}{c}-0.075^{\text {*** }} \\
(0.020)\end{array}$ & $\begin{array}{l}-0.081^{* * *} \\
(0.023)\end{array}$ & $\begin{array}{c}388.868^{* * *} \\
(72.752)\end{array}$ & $\begin{array}{c}384.035^{* * *} \\
(94.734)\end{array}$ & $\begin{array}{c}667.352^{* * *} \\
(161.392)\end{array}$ & $\begin{array}{c}275.009 \\
(197.270)\end{array}$ \\
\hline 1998 & $\begin{array}{c}-0.066^{* * *} \\
(0.023)\end{array}$ & $\begin{array}{l}-0.083^{* * *} \\
(0.026)\end{array}$ & $\begin{array}{c}300.085^{* * *} \\
(78.661)\end{array}$ & $\begin{array}{c}337.408^{* * * *} \\
(90.444)\end{array}$ & $\begin{array}{l}492.394^{* * *} \\
(140.127)\end{array}$ & $\begin{array}{l}415.922^{* *} \\
(180.262)\end{array}$ \\
\hline 1999 & $\begin{array}{c}-0.057^{* * *} \\
(0.022)\end{array}$ & $\begin{array}{c}-0.072^{* * *} \\
(0.025)\end{array}$ & $\begin{array}{c}422.997^{* * *} \\
(81.376)\end{array}$ & $\begin{array}{l}461.207^{* * *} \\
(103.010)\end{array}$ & $\begin{array}{l}704.544^{* * *} \\
(182.821)\end{array}$ & $\begin{array}{c}661.163^{* * *} \\
(239.409)\end{array}$ \\
\hline 2000 & $\begin{array}{l}-0.041^{* *} \\
(0.018)\end{array}$ & $\begin{array}{l}-0.015 \\
(0.021)\end{array}$ & $\begin{array}{c}-1,269.187^{* * *} \\
(69.595)\end{array}$ & $\begin{array}{c}-1,478.420^{* * *} \\
(80.247)\end{array}$ & $\begin{array}{c}-1,522.271^{* * * *} \\
(169.333)\end{array}$ & $\begin{array}{c}-926.784^{* * *} \\
(234.372)\end{array}$ \\
\hline 2001 & $\begin{array}{c}-0.074^{* * *} \\
(0.017)\end{array}$ & $\begin{array}{l}-0.045^{* *} \\
(0.020)\end{array}$ & $\begin{array}{c}-1,041.225^{* * *} \\
(71.556)\end{array}$ & $\begin{array}{c}-1,227.253^{* * *} \\
(77.934)\end{array}$ & $\begin{array}{c}-1,333.611^{* * * *} \\
(165.318)\end{array}$ & $\begin{array}{c}-752.136^{* * * *} \\
(219.987)\end{array}$ \\
\hline 2002 & $\begin{array}{c}-0.064^{* * *} \\
(0.016)\end{array}$ & $\begin{array}{l}-0.032^{*} \\
(0.018)\end{array}$ & $\begin{array}{c}-1,150.879^{* * *} \\
(64.895)\end{array}$ & $\begin{array}{c}-1,355.153^{* * *} \\
(71.754)\end{array}$ & $\begin{array}{c}-1,204.076^{* * * *} \\
(174.387)\end{array}$ & $\begin{array}{c}-886.483^{* * *} \\
(229.072)\end{array}$ \\
\hline 2003 & $\begin{array}{c}-0.072^{* * *} \\
(0.016)\end{array}$ & $\begin{array}{l}-0.046^{* *} \\
(0.018)\end{array}$ & $\begin{array}{c}-888.988^{* * *} \\
(64.928)\end{array}$ & $\begin{array}{c}-1,052.152^{* * *} \\
(67.017)\end{array}$ & $\begin{array}{c}-874.287^{* * *} \\
(193.028)\end{array}$ & $\begin{array}{l}-389.783^{*} \\
(235.128)\end{array}$ \\
\hline 2004 & $\begin{array}{c}-0.098^{* * *} \\
(0.014)\end{array}$ & $\begin{array}{l}-0.071^{* * *} \\
(0.016)\end{array}$ & $\begin{array}{c}-841.970^{* * *} \\
(62.094)\end{array}$ & $\begin{array}{c}-1,002.528^{* * *} \\
(62.076)\end{array}$ & $\begin{array}{c}-983.238^{* * *} \\
(177.457)\end{array}$ & $\begin{array}{c}-660.701^{* * *} \\
(215.689)\end{array}$ \\
\hline 2005 & $\begin{array}{c}-0.082^{* * *} \\
(0.015)\end{array}$ & $\begin{array}{l}-0.054^{* * *} \\
(0.015)\end{array}$ & $\begin{array}{c}-664.132^{* * *} \\
(69.039)\end{array}$ & $\begin{array}{c}-784.712^{* * *} \\
(67.299)\end{array}$ & $\begin{array}{c}-824.044^{* * *} \\
(193.099)\end{array}$ & $\begin{array}{l}-425.167^{*} \\
(233.082)\end{array}$ \\
\hline 2006 & $\begin{array}{c}-0.096^{* * *} \\
(0.014)\end{array}$ & $\begin{array}{l}-0.076^{* * *} \\
(0.015)\end{array}$ & $\begin{array}{c}-770.410^{* * *} \\
(59.123)\end{array}$ & $\begin{array}{c}-870.045^{* * *} \\
(57.382)\end{array}$ & $\begin{array}{c}-1,012.836^{* * *} \\
(176.207)\end{array}$ & $\begin{array}{c}-627.540^{* * *} \\
(218.963)\end{array}$ \\
\hline 2007 & $\begin{array}{c}-0.066^{* * *} \\
(0.012)\end{array}$ & $\begin{array}{l}-0.048^{* * *} \\
(0.013)\end{array}$ & $\begin{array}{c}-424.819^{* * *} \\
(61.829)\end{array}$ & $\begin{array}{c}-550.857^{* * *} \\
(59.097)\end{array}$ & $\begin{array}{c}-539.312^{* * *} \\
(179.406)\end{array}$ & $\begin{array}{l}-189.100 \\
(211.091)\end{array}$ \\
\hline 2008 & $\begin{array}{c}-0.052^{* * *} \\
(0.013)\end{array}$ & $\begin{array}{l}-0.043^{* * *} \\
(0.013)\end{array}$ & $\begin{array}{c}-389.200^{* * *} \\
(64.839)\end{array}$ & $\begin{array}{c}-480.176^{* * *} \\
(59.321)\end{array}$ & $\begin{array}{c}-577.387^{* * *} \\
(177.067)\end{array}$ & $\begin{array}{l}-173.328 \\
(201.554)\end{array}$ \\
\hline 2009 & $\begin{array}{l}-0.027^{* *} \\
(0.014)\end{array}$ & $\begin{array}{l}-0.020 \\
(0.014)\end{array}$ & $\begin{array}{c}-264.325^{* * *} \\
(63.731)\end{array}$ & $\begin{array}{c}-296.491^{* * * *} \\
(59.563)\end{array}$ & $\begin{array}{c}-668.495^{* * *} \\
(189.905)\end{array}$ & $\begin{array}{l}-384.623^{*} \\
(219.347)\end{array}$ \\
\hline 2010 & $\begin{array}{c}-0.049^{* * *} \\
(0.011)\end{array}$ & $\begin{array}{l}-0.041^{* * *} \\
(0.012)\end{array}$ & $\begin{array}{l}-61.464 \\
(57.820)\end{array}$ & $\begin{array}{l}-98.996^{*} \\
(53.655)\end{array}$ & $\begin{array}{l}-131.445 \\
(199.365)\end{array}$ & $\begin{array}{c}102.480 \\
(226.611)\end{array}$ \\
\hline Constant & $\begin{array}{l}0.240^{* * * *} \\
(0.023)\end{array}$ & & $\begin{array}{c}1,800.541^{* * *} \\
(120.870)\end{array}$ & & $\begin{array}{c}1,608.348^{* * * *} \\
(174.677)\end{array}$ & \\
\hline Observations & 44,867 & 44,867 & 44,867 & 44,867 & 8,933 & 8,933 \\
\hline $\mathbf{R}^{2}$ & 0.019 & 0.132 & 0.097 & 0.364 & 0.121 & 0.547 \\
\hline
\end{tabular}


Appendix Table 6. Impact of EU-ODA on Early-stage Investment by Origin of VCs -

Results with All Controls. This table replicates Table 4 reporting the coefficient estimates for our full set of fixed effects at the technology category and year level. In addition this table reports coefficient estimates for all our controls in the baseline specification. Standard errors are clustered at the investing firm level. ${ }^{*} \mathrm{p}<0.10 ;{ }^{* *} \mathrm{p}<0.05 ;{ }^{* *} \mathrm{p}<0.01$.

\begin{tabular}{|c|c|c|c|c|}
\hline & \multicolumn{4}{|c|}{ Dependent variables } \\
\hline & $\begin{array}{c}\text { Early-stage } \\
\text { (1) }\end{array}$ & $\begin{array}{l}\text { Time to inv. } \\
\text { (2) }\end{array}$ & $\begin{array}{c}\text { Early-stage } \\
\text { (3) }\end{array}$ & $\begin{array}{l}\text { Time to inv. } \\
\text { (4) }\end{array}$ \\
\hline Drug-related & $\begin{array}{l}0.136^{*} \\
(0.080)\end{array}$ & $\begin{array}{l}-620.537^{*} \\
(347.650)\end{array}$ & $\begin{array}{l}-0.077 \\
(0.048)\end{array}$ & $\begin{array}{l}2,488.061^{*} \\
(1,476.213)\end{array}$ \\
\hline After ODA & $\begin{array}{c}0.076 \\
(0.180)\end{array}$ & $\begin{array}{c}2,430.350^{* * *} \\
(390.199)\end{array}$ & $\begin{array}{l}-0.286 \\
(0.263)\end{array}$ & $\begin{array}{c}3,474.732^{* * *} \\
(1,305.922)\end{array}$ \\
\hline $\begin{array}{l}\text { Drug-related } \\
\text { *After ODA }\end{array}$ & $\begin{array}{l}-0.010 \\
(0.076)\end{array}$ & $\begin{array}{c}170.629 \\
(277.629)\end{array}$ & $\begin{array}{l}0.324^{* * * *} \\
(0.110)\end{array}$ & $\begin{array}{r}-1,481.601^{* *} \\
(749.362)\end{array}$ \\
\hline Biosensors & $\begin{array}{l}0.136^{*} \\
(0.076)\end{array}$ & $\begin{array}{l}-125.233 \\
(524.991)\end{array}$ & $\begin{array}{c}0.158 \\
(0.161)\end{array}$ & $\begin{array}{c}-1,493.060 \\
(987.439)\end{array}$ \\
\hline Biotech Equipment & $\begin{array}{l}0.145^{* *} \\
(0.061)\end{array}$ & $\begin{array}{l}-131.030 \\
(463.175)\end{array}$ & $\begin{array}{c}0.155 \\
(0.116)\end{array}$ & $\begin{array}{c}480.606 \\
(1,128.133)\end{array}$ \\
\hline Biotech Other & $\begin{array}{c}0.327^{* * *} \\
(0.115)\end{array}$ & $\begin{array}{l}-950.853 \\
(839.002)\end{array}$ & $(0.000)$ & $(0.00000)$ \\
\hline Biotech Research & $\begin{array}{c}0.008 \\
(0.039)\end{array}$ & $\begin{array}{l}-718.222^{*} \\
(384.610)\end{array}$ & $\begin{array}{c}0.001 \\
(0.167)\end{array}$ & $\begin{array}{l}-1,552.957 \\
(1,590.125)\end{array}$ \\
\hline Biotech-Animal & $\begin{array}{c}0.081 \\
(0.076)\end{array}$ & $\begin{array}{c}-944.741^{* *} \\
(428.242)\end{array}$ & $\begin{array}{c}0.154 \\
(0.399)\end{array}$ & $\begin{array}{c}-114.051 \\
(1,003.338)\end{array}$ \\
\hline Biotech-Industrial & $\begin{array}{c}0.019 \\
(0.062)\end{array}$ & $\begin{array}{c}383.540 \\
(518.706)\end{array}$ & $\begin{array}{l}0.331^{*} \\
(0.180)\end{array}$ & $\begin{array}{c}2,699.118^{*} \\
(1,513.765)\end{array}$ \\
\hline Biotech-Human & $\begin{array}{l}-0.046 \\
(0.029)\end{array}$ & $\begin{array}{c}-67.169 \\
(117.156)\end{array}$ & $\begin{array}{l}-0.204^{*} \\
(0.114)\end{array}$ & $\begin{array}{l}-1,300.283 \\
(1,040.984)\end{array}$ \\
\hline Med/Health Products & $\begin{array}{l}-0.074^{*} \\
(0.039)\end{array}$ & $\begin{array}{c}1,107.010^{* * *} \\
(314.097)\end{array}$ & $\begin{array}{l}-0.069 \\
(0.126)\end{array}$ & $\begin{array}{c}246.025 \\
(992.916)\end{array}$ \\
\hline Pharmaceutical & $\begin{array}{l}-0.017 \\
(0.032)\end{array}$ & $\begin{array}{l}-149.897 \\
(127.263)\end{array}$ & $\begin{array}{l}-0.151 \\
(0.111)\end{array}$ & $\begin{array}{l}-2,110.340 \\
(1,406.311)\end{array}$ \\
\hline 1990 & $\begin{array}{c}0.259 \\
(0.167)\end{array}$ & $\begin{array}{c}82.346 \\
(372.270)\end{array}$ & $\begin{array}{l}-0.378^{*} \\
(0.203)\end{array}$ & $\begin{array}{c}474.536 \\
(564.374)\end{array}$ \\
\hline 1991 & $\begin{array}{l}-0.004 \\
(0.115)\end{array}$ & $\begin{array}{c}229.597 \\
(377.699)\end{array}$ & $\begin{array}{l}-0.280 \\
(0.369)\end{array}$ & $\begin{array}{l}798.252^{* * *} \\
(160.137)\end{array}$ \\
\hline 1992 & $\begin{array}{l}-0.026 \\
(0.159)\end{array}$ & $\begin{array}{c}1,108.321^{* * *} \\
(412.440)\end{array}$ & $\begin{array}{l}-0.516^{* *} \\
(0.215)\end{array}$ & $\begin{array}{l}930.168^{* *} \\
(468.671)\end{array}$ \\
\hline 1993 & $\begin{array}{c}0.315 \\
(0.251)\end{array}$ & $\begin{array}{l}834.142^{* * *} \\
(207.546)\end{array}$ & $\begin{array}{l}-0.106 \\
(0.240)\end{array}$ & $\begin{array}{c}224.921 \\
(421.310)\end{array}$ \\
\hline
\end{tabular}




\begin{tabular}{|c|c|c|c|c|}
\hline 1994 & $\begin{array}{l}-0.026 \\
(0.156)\end{array}$ & $\begin{array}{c}1,226.351^{* * *} \\
(461.322)\end{array}$ & $\begin{array}{l}-0.315 \\
(0.246)\end{array}$ & $\begin{array}{c}147.347 \\
(361.990)\end{array}$ \\
\hline 1995 & $\begin{array}{l}-0.146 \\
(0.165)\end{array}$ & $\begin{array}{c}1,196.773^{* *} \\
(600.766)\end{array}$ & $\begin{array}{l}-0.265 \\
(0.232)\end{array}$ & $\begin{array}{c}249.125 \\
(649.679)\end{array}$ \\
\hline 1996 & $\begin{array}{c}0.053 \\
(0.238)\end{array}$ & $\begin{array}{c}1,247.267^{* * *} \\
(247.611)\end{array}$ & $\begin{array}{l}-0.442^{* *} \\
(0.217)\end{array}$ & $\begin{array}{c}-36.486 \\
(656.135)\end{array}$ \\
\hline 1997 & $\begin{array}{c}0.080 \\
(0.194)\end{array}$ & $\begin{array}{l}712.605^{* * *} \\
(239.981)\end{array}$ & $\begin{array}{l}-0.233 \\
(0.253)\end{array}$ & $\begin{array}{c}251.062 \\
(303.955)\end{array}$ \\
\hline 1998 & $\begin{array}{c}0.147 \\
(0.183)\end{array}$ & $\begin{array}{l}574.480^{* *} \\
(246.881)\end{array}$ & $\begin{array}{l}-0.235 \\
(0.222)\end{array}$ & $\begin{array}{c}539.442 \\
(533.520)\end{array}$ \\
\hline 1999 & $\begin{array}{c}0.157 \\
(0.156)\end{array}$ & $\begin{array}{l}453.774^{* *} \\
(228.948)\end{array}$ & $\begin{array}{l}-0.059 \\
(0.245)\end{array}$ & $\begin{array}{r}1,714.879 \\
(1,112.123)\end{array}$ \\
\hline 2000 & $\begin{array}{c}0.023 \\
(0.047)\end{array}$ & $\begin{array}{c}-1,894.845^{* * *} \\
(193.061)\end{array}$ & $\begin{array}{c}0.033 \\
(0.152)\end{array}$ & $\begin{array}{c}-930.940 \\
(1,306.377)\end{array}$ \\
\hline 2001 & $\begin{array}{l}-0.100^{* *} \\
(0.045)\end{array}$ & $\begin{array}{c}-1,739.647^{* * *} \\
(225.597)\end{array}$ & $\begin{array}{l}-0.265^{*} \\
(0.140)\end{array}$ & $\begin{array}{l}-1,225.566 \\
(1,131.532)\end{array}$ \\
\hline 2002 & $\begin{array}{l}-0.067 \\
(0.051)\end{array}$ & $\begin{array}{c}-1,681.353^{* * *} \\
(201.654)\end{array}$ & $\begin{array}{l}-0.222 \\
(0.141)\end{array}$ & $\begin{array}{c}-1,442.428 \\
(946.704)\end{array}$ \\
\hline 2003 & $\begin{array}{l}-0.059 \\
(0.047)\end{array}$ & $\begin{array}{c}-1,039.189^{* * *} \\
(206.610)\end{array}$ & $\begin{array}{l}-0.197 \\
(0.174)\end{array}$ & $\begin{array}{c}-822.910 \\
(1,112.675)\end{array}$ \\
\hline 2004 & $\begin{array}{c}-0.118^{* * *} \\
(0.042)\end{array}$ & $\begin{array}{c}-1,077.749^{* * *} \\
(189.246)\end{array}$ & $\begin{array}{l}-0.199 \\
(0.162)\end{array}$ & $\begin{array}{c}-849.614 \\
(1,110.303)\end{array}$ \\
\hline 2005 & $\begin{array}{c}-0.114^{* * *} \\
(0.040)\end{array}$ & $\begin{array}{c}-769.945^{* * *} \\
(204.820)\end{array}$ & $\begin{array}{l}-0.293^{* *} \\
(0.135)\end{array}$ & $\begin{array}{c}-540.012 \\
(1,067.378)\end{array}$ \\
\hline 2006 & $\begin{array}{c}-0.178^{* * *} \\
(0.046)\end{array}$ & $\begin{array}{c}-926.750^{* * *} \\
(182.213)\end{array}$ & $\begin{array}{l}-0.236^{*} \\
(0.137)\end{array}$ & $\begin{array}{l}-716.939 \\
(869.076)\end{array}$ \\
\hline 2007 & $\begin{array}{l}-0.067 \\
(0.046)\end{array}$ & $\begin{array}{c}-591.240^{* * *} \\
(193.899)\end{array}$ & $\begin{array}{l}-0.183 \\
(0.134)\end{array}$ & $\begin{array}{l}-192.114 \\
(700.082)\end{array}$ \\
\hline 2008 & $\begin{array}{l}-0.090^{* *} \\
(0.046)\end{array}$ & $\begin{array}{c}-766.370^{* * * *} \\
(176.352)\end{array}$ & $\begin{array}{l}-0.132 \\
(0.107)\end{array}$ & $\begin{array}{l}-356.277 \\
(645.989)\end{array}$ \\
\hline 2009 & $\begin{array}{l}-0.056 \\
(0.044)\end{array}$ & $\begin{array}{l}-182.448 \\
(182.520)\end{array}$ & $\begin{array}{l}-0.085 \\
(0.114)\end{array}$ & $\begin{array}{l}-383.851 \\
(696.617)\end{array}$ \\
\hline 2010 & $\begin{array}{l}-0.077^{* *} \\
(0.037)\end{array}$ & $\begin{array}{c}-86.137 \\
(191.167)\end{array}$ & $\begin{array}{l}-0.119 \\
(0.113)\end{array}$ & $\begin{array}{c}71.672 \\
(729.395)\end{array}$ \\
\hline Observations & 4,695 & 4,695 & 809 & 809 \\
\hline $\mathbf{R}^{2}$ & 0.229 & 0.479 & 0.411 & 0.564 \\
\hline
\end{tabular}


Appendix Table 7. Impact of EU-ODA on Early-stage Investment by Origin of Startups Results with All Controls. This table replicates Table 5 reporting the coefficient estimates for our full set of fixed effects at the technology category and year level. In addition this table reports coefficient estimates for all our controls in the baseline specification. Standard errors are clustered at the industry category level. ${ }^{*} \mathrm{p}<0.10 ;{ }^{* *} \mathrm{p}<0.05 ;{ }^{* * *} \mathrm{p}<0.01$.

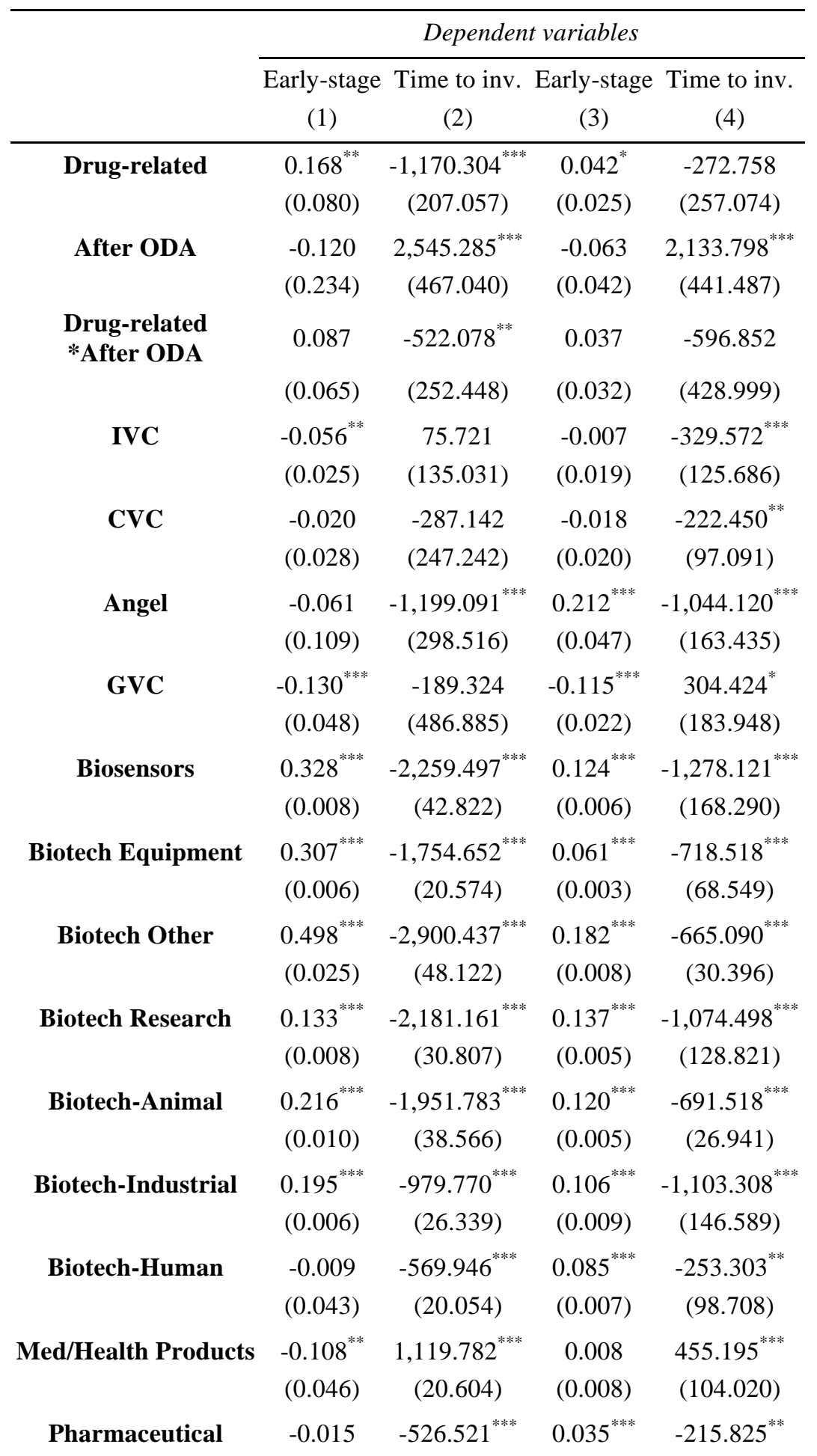




\begin{tabular}{|c|c|c|c|c|}
\hline & (0.043) & (23.580) & $(0.006)$ & (104.356) \\
\hline 1990 & $\begin{array}{l}-0.044 \\
(0.296)\end{array}$ & $\begin{array}{c}240.926 \\
(651.475)\end{array}$ & $\begin{array}{l}-0.063 \\
(0.050)\end{array}$ & $\begin{array}{c}245.165^{* * *} \\
(59.962)\end{array}$ \\
\hline 1991 & $\begin{array}{l}-0.110 \\
(0.312)\end{array}$ & $\begin{array}{l}851.367^{*} \\
(496.534)\end{array}$ & $\begin{array}{l}-0.080^{* * *} \\
(0.018)\end{array}$ & $\begin{array}{c}383.353^{* * *} \\
(57.253)\end{array}$ \\
\hline 1992 & $\begin{array}{l}-0.315 \\
(0.230)\end{array}$ & $\begin{array}{c}1,757.127^{* * *} \\
(446.768)\end{array}$ & $\begin{array}{l}-0.108^{* * *} \\
(0.017)\end{array}$ & $\begin{array}{l}225.856^{* *} \\
(113.204)\end{array}$ \\
\hline 1993 & $\begin{array}{l}-0.040 \\
(0.288)\end{array}$ & $\begin{array}{l}561.157^{*} \\
(302.910)\end{array}$ & $\begin{array}{l}-0.095^{* * *} \\
(0.029)\end{array}$ & $\begin{array}{l}143.552 \\
(88.920)\end{array}$ \\
\hline 1994 & $\begin{array}{l}-0.275 \\
(0.253)\end{array}$ & $\begin{array}{c}1,422.982^{* * *} \\
(265.656)\end{array}$ & $\begin{array}{c}-0.122^{* * *} \\
(0.028)\end{array}$ & $\begin{array}{c}200.447^{* *} \\
(85.484)\end{array}$ \\
\hline 1995 & $\begin{array}{l}-0.281 \\
(0.241)\end{array}$ & $\begin{array}{c}1,417.179^{* * *} \\
(511.375)\end{array}$ & $\begin{array}{c}-0.096^{* * *} \\
(0.035)\end{array}$ & $\begin{array}{c}307.344^{* * *} \\
(71.997)\end{array}$ \\
\hline 1996 & $\begin{array}{l}-0.271 \\
(0.238)\end{array}$ & $\begin{array}{c}865.367^{* * *} \\
(100.211)\end{array}$ & $\begin{array}{c}-0.128^{* * *} \\
(0.038)\end{array}$ & $\begin{array}{c}217.417^{* * * *} \\
(74.693)\end{array}$ \\
\hline 1997 & $\begin{array}{l}-0.170 \\
(0.246)\end{array}$ & $\begin{array}{l}828.385^{* *} \\
(339.019)\end{array}$ & $\begin{array}{l}-0.082^{* *} \\
(0.035)\end{array}$ & $\begin{array}{l}387.355^{* * *} \\
(140.073)\end{array}$ \\
\hline 1998 & $\begin{array}{l}-0.095 \\
(0.258)\end{array}$ & $\begin{array}{l}463.708^{*} \\
(260.247)\end{array}$ & $\begin{array}{l}-0.077^{* *} \\
(0.030)\end{array}$ & $\begin{array}{c}287.091^{* * *} \\
(109.080)\end{array}$ \\
\hline 1999 & $\begin{array}{l}-0.052 \\
(0.222)\end{array}$ & $\begin{array}{l}787.726^{* *} \\
(365.601)\end{array}$ & $\begin{array}{l}-0.068^{* *} \\
(0.031)\end{array}$ & $\begin{array}{l}392.648^{* * *} \\
(139.374)\end{array}$ \\
\hline 2000 & $\begin{array}{l}-0.058 \\
(0.037)\end{array}$ & $\begin{array}{c}-1,186.895^{* * *} \\
(187.329)\end{array}$ & $\begin{array}{l}-0.081^{*} \\
(0.044)\end{array}$ & $\begin{array}{c}-1,177.574^{* * * *} \\
(151.716)\end{array}$ \\
\hline 2001 & $\begin{array}{l}-0.175^{* * *} \\
(0.047)\end{array}$ & $\begin{array}{c}-1,220.529^{* * *} \\
(147.386)\end{array}$ & $\begin{array}{l}-0.086 \\
(0.053)\end{array}$ & $\begin{array}{c}-888.220^{* * *} \\
(119.905)\end{array}$ \\
\hline 2002 & $\begin{array}{c}-0.172^{* * *} \\
(0.022)\end{array}$ & $\begin{array}{c}-1,088.862^{* * *} \\
(121.741)\end{array}$ & $\begin{array}{l}-0.060 \\
(0.043)\end{array}$ & $\begin{array}{c}-1,090.565^{* * * *} \\
(100.517)\end{array}$ \\
\hline 2003 & $\begin{array}{c}-0.117^{* * *} \\
(0.033)\end{array}$ & $\begin{array}{c}-673.680^{* * * *} \\
(142.806)\end{array}$ & $\begin{array}{l}-0.083^{*} \\
(0.048)\end{array}$ & $\begin{array}{c}-868.121^{* * *} \\
(81.612)\end{array}$ \\
\hline 2004 & $\begin{array}{c}-0.182^{* * *} \\
(0.062)\end{array}$ & $\begin{array}{l}-538.447^{* *} \\
(240.855)\end{array}$ & $\begin{array}{l}-0.094^{*} \\
(0.052)\end{array}$ & $\begin{array}{c}-865.830^{* * *} \\
(107.884)\end{array}$ \\
\hline 2005 & $\begin{array}{c}-0.177^{* * *} \\
(0.060)\end{array}$ & $\begin{array}{l}-441.240^{*} \\
(259.099)\end{array}$ & $\begin{array}{l}-0.072 \\
(0.053)\end{array}$ & $\begin{array}{c}-689.006^{* * *} \\
(130.341)\end{array}$ \\
\hline 2006 & $\begin{array}{c}-0.196^{* * *} \\
(0.050)\end{array}$ & $\begin{array}{c}-650.912^{* * *} \\
(226.903)\end{array}$ & $\begin{array}{l}-0.087^{*} \\
(0.049)\end{array}$ & $\begin{array}{c}-791.336^{* * *} \\
(85.189)\end{array}$ \\
\hline 2007 & $\begin{array}{c}-0.112^{* * *} \\
(0.037)\end{array}$ & $\begin{array}{l}-125.999 \\
(277.044)\end{array}$ & $\begin{array}{l}-0.074^{* *} \\
(0.031)\end{array}$ & $\begin{array}{c}-409.165^{* * *} \\
(57.700)\end{array}$ \\
\hline 2008 & $\begin{array}{c}-0.102^{* * *} \\
(0.039)\end{array}$ & $\begin{array}{l}-434.211 \\
(265.478)\end{array}$ & $\begin{array}{l}-0.057^{* *} \\
(0.027)\end{array}$ & $\begin{array}{c}-355.808^{* * *} \\
(67.925)\end{array}$ \\
\hline 2009 & $-0.060^{*}$ & -16.066 & -0.029 & $-296.128^{* * *}$ \\
\hline
\end{tabular}




\begin{tabular}{ccccc} 
& $(0.034)$ & $(164.975)$ & $(0.039)$ & $(80.077)$ \\
$\mathbf{2 0 1 0}$ & $-0.092^{* *}$ & 74.052 & $-0.044^{* *}$ & -119.386 \\
& $(0.043)$ & $(154.295)$ & $(0.021)$ & $(76.092)$ \\
Constant & 0.310 & $2,084.532^{* * *}$ & $0.230^{* * *}$ & $1,939.239^{* * *}$ \\
& $(0.228)$ & $(361.555)$ & $(0.023)$ & $(191.657)$ \\
\hline Observations & 6,223 & 6,223 & 35,876 & 35,876 \\
$\mathbf{R}^{2}$ & 0.054 & 0.175 & 0.020 & 0.090 \\
\hline
\end{tabular}


Appendix Table 8. Syndication of VC Investments - Results with All Controls. This table replicates Table 6 reporting the coefficient estimates for our full set of fixed effects at the technology category and year level. In addition this table reports coefficient estimates for all our controls in the baseline specification. Standard errors are clustered at the investing firm level. ${ }^{*} \mathrm{p}<0.10 ;{ }^{* *} \mathrm{p}<0.05 ;{ }^{* * *} \mathrm{p}<0.01$.

\begin{tabular}{|c|c|c|c|}
\hline & \multicolumn{3}{|c|}{ Dependent variables } \\
\hline & \multicolumn{3}{|c|}{ Number of investors } \\
\hline & (1) & (2) & (3) \\
\hline & Total & Early-stage & Late-stage \\
\hline \multirow[t]{2}{*}{ Drug-related } & $0.468^{* * *}$ & $0.954^{* * * *}$ & $0.658^{* * *}$ \\
\hline & $(0.160)$ & $(0.247)$ & $(0.195)$ \\
\hline \multirow[t]{2}{*}{ After ODA } & $-1.356^{* * * *}$ & $-2.990^{* * *}$ & $-0.580^{*}$ \\
\hline & $(0.250)$ & $(0.490)$ & $(0.313)$ \\
\hline \multirow[t]{2}{*}{$\begin{array}{l}\text { Drug-related } \\
* \text { After ODA }\end{array}$} & $0.454^{* * *}$ & $-0.475^{* *}$ & $0.606^{* * * *}$ \\
\hline & $(0.136)$ & $(0.237)$ & $(0.186)$ \\
\hline \multirow[t]{2}{*}{ EU startups } & $0.376^{*}$ & 0.333 & 0.225 \\
\hline & $(0.200)$ & $(0.349)$ & $(0.251)$ \\
\hline \multirow[t]{2}{*}{ US startups } & $1.666^{* * *}$ & $0.659^{* *}$ & $2.137^{* * * *}$ \\
\hline & $(0.168)$ & $(0.320)$ & $(0.216)$ \\
\hline \multirow[t]{2}{*}{ Biosensors } & $0.629^{* * *}$ & 0.322 & $0.710^{* *}$ \\
\hline & $(0.241)$ & $(0.357)$ & $(0.336)$ \\
\hline \multirow[t]{2}{*}{ Biotech Equipment } & $0.677^{* * *}$ & 0.167 & $1.039^{* * *}$ \\
\hline & $(0.196)$ & $(0.300)$ & $(0.246)$ \\
\hline \multirow[t]{2}{*}{ Biotech Other } & -0.314 & -0.070 & -0.324 \\
\hline & $(0.436)$ & $(0.450)$ & $(0.724)$ \\
\hline \multirow[t]{2}{*}{ Biotech Research } & $1.131^{* * * *}$ & $1.283^{* * *}$ & $1.756^{* * *}$ \\
\hline & $(0.168)$ & $(0.343)$ & $(0.203)$ \\
\hline \multirow[t]{2}{*}{ Biotech-Animal } & $1.044^{* * *}$ & $1.211^{* * *}$ & $1.345^{* * *}$ \\
\hline & $(0.214)$ & $(0.403)$ & $(0.310)$ \\
\hline \multirow[t]{2}{*}{ Biotech-Industrial } & $0.852^{* * *}$ & $0.667^{* *}$ & $1.325^{* * *}$ \\
\hline & $(0.229)$ & $(0.307)$ & $(0.288)$ \\
\hline \multirow[t]{2}{*}{ Biotech-Human } & $0.656^{* * *}$ & $0.698^{* * *}$ & $1.223^{* * *}$ \\
\hline & $(0.077)$ & $(0.115)$ & $(0.116)$ \\
\hline \multirow[t]{2}{*}{ Med/Health Products } & -0.098 & $-0.435^{* * *}$ & -0.002 \\
\hline & $(0.106)$ & $(0.162)$ & $(0.149)$ \\
\hline \multirow[t]{2}{*}{ Pharmaceutical } & $0.399^{* * *}$ & $0.235^{*}$ & $0.783^{* * *}$ \\
\hline & (0.089) & $(0.122)$ & $(0.126)$ \\
\hline \multirow[t]{2}{*}{1990} & $-0.575^{* *}$ & $-3.433^{* * *}$ & $0.624^{* *}$ \\
\hline & $(0.238)$ & $(0.516)$ & $(0.306)$ \\
\hline
\end{tabular}




\begin{tabular}{|c|c|c|c|}
\hline 1991 & $\begin{array}{c}-1.733^{* * *} \\
(0.194)\end{array}$ & $\begin{array}{c}-3.946^{* * *} \\
(0.508)\end{array}$ & $\begin{array}{c}-1.126^{* * *} \\
(0.303)\end{array}$ \\
\hline 1992 & $\begin{array}{c}-0.822^{* * * *} \\
(0.216)\end{array}$ & $\begin{array}{c}-3.479^{* * *} \\
(0.487)\end{array}$ & $\begin{array}{l}-0.077 \\
(0.310)\end{array}$ \\
\hline 1993 & $\begin{array}{c}-1.114^{* * * *} \\
(0.238)\end{array}$ & $\begin{array}{c}-2.999^{* * * *} \\
(0.473)\end{array}$ & $\begin{array}{l}-0.142 \\
(0.362)\end{array}$ \\
\hline 1994 & $\begin{array}{c}-0.903^{\text {**** }} \\
(0.245)\end{array}$ & $\begin{array}{c}-1.744^{* * * *} \\
(0.554)\end{array}$ & $\begin{array}{c}0.068 \\
(0.308)\end{array}$ \\
\hline 1995 & $\begin{array}{c}-0.983^{* * * *} \\
(0.242)\end{array}$ & $\begin{array}{c}-3.722^{* * *} \\
(0.456)\end{array}$ & $\begin{array}{c}0.098 \\
(0.305)\end{array}$ \\
\hline 1996 & $\begin{array}{c}-1.417^{* * *} \\
(0.220)\end{array}$ & $\begin{array}{c}-3.653^{* * *} \\
(0.469)\end{array}$ & $\begin{array}{c}-0.642^{* *} \\
(0.284)\end{array}$ \\
\hline 1997 & $\begin{array}{c}-0.711^{* * *} \\
(0.236)\end{array}$ & $\begin{array}{c}-3.778^{* * *} \\
(0.486)\end{array}$ & $\begin{array}{l}0.522^{*} \\
(0.288)\end{array}$ \\
\hline 1998 & $\begin{array}{c}-0.875^{\text {**** }} \\
(0.220)\end{array}$ & $\begin{array}{c}-3.993^{* * *} \\
(0.472)\end{array}$ & $\begin{array}{c}0.394 \\
(0.285)\end{array}$ \\
\hline 1999 & $\begin{array}{c}-0.928^{* * * *} \\
(0.226)\end{array}$ & $\begin{array}{c}-3.947^{* * *} \\
(0.462)\end{array}$ & $\begin{array}{l}-0.227 \\
(0.262)\end{array}$ \\
\hline 2000 & $\begin{array}{c}0.677^{* * *} \\
(0.142)\end{array}$ & $\begin{array}{l}-0.354 \\
(0.240)\end{array}$ & $\begin{array}{c}0.604^{* * *} \\
(0.183)\end{array}$ \\
\hline 2001 & $\begin{array}{l}1.228^{* * *} \\
(0.142)\end{array}$ & $\begin{array}{c}0.090 \\
(0.235)\end{array}$ & $\begin{array}{l}1.239^{* * *} \\
(0.193)\end{array}$ \\
\hline 2002 & $\begin{array}{l}1.218^{* * *} \\
(0.145)\end{array}$ & $\begin{array}{c}0.224 \\
(0.224)\end{array}$ & $\begin{array}{l}1.150^{* * *} \\
(0.182)\end{array}$ \\
\hline 2003 & $\begin{array}{l}0.913^{* * *} \\
(0.140)\end{array}$ & $\begin{array}{l}-0.188 \\
(0.198)\end{array}$ & $\begin{array}{c}0.850^{* * *} \\
(0.198)\end{array}$ \\
\hline 2004 & $\begin{array}{l}1.010^{* * *} \\
(0.125)\end{array}$ & $\begin{array}{l}-0.059 \\
(0.163)\end{array}$ & $\begin{array}{c}0.882^{* * *} \\
(0.156)\end{array}$ \\
\hline 2005 & $\begin{array}{l}1.113^{* * *} \\
(0.104)\end{array}$ & $\begin{array}{l}0.405^{* *} \\
(0.182)\end{array}$ & $\begin{array}{c}0.852^{* * *} \\
(0.144)\end{array}$ \\
\hline 2006 & $\begin{array}{l}0.822^{* * *} \\
(0.103)\end{array}$ & $\begin{array}{l}-0.282^{*} \\
(0.171)\end{array}$ & $\begin{array}{l}0.751^{* * *} \\
(0.151)\end{array}$ \\
\hline 2007 & $\begin{array}{l}0.863^{* * *} \\
(0.106)\end{array}$ & $\begin{array}{c}0.063 \\
(0.148)\end{array}$ & $\begin{array}{l}0.873^{* * *} \\
(0.159)\end{array}$ \\
\hline 2008 & $\begin{array}{c}0.517^{* * *} \\
(0.096)\end{array}$ & $\begin{array}{c}0.036 \\
(0.126)\end{array}$ & $\begin{array}{l}0.551^{* * *} \\
(0.135)\end{array}$ \\
\hline 2009 & $\begin{array}{l}-0.099 \\
(0.076)\end{array}$ & $\begin{array}{c}0.035 \\
(0.148)\end{array}$ & $\begin{array}{l}-0.254^{* *} \\
(0.123)\end{array}$ \\
\hline 2010 & $\begin{array}{c}-0.249^{* * *} \\
(0.075)\end{array}$ & $\begin{array}{l}-0.163 \\
(0.138)\end{array}$ & $\begin{array}{l}-0.294^{* *} \\
(0.132)\end{array}$ \\
\hline
\end{tabular}




\begin{tabular}{cccc}
\hline Observations & 44,867 & 9,547 & 25,375 \\
$\mathbf{R}^{\mathbf{2}}$ & 0.265 & 0.369 & 0.354 \\
\hline
\end{tabular}


Appendix Table 9. Syndication of VC Investments with Alternative Time Periods Before and After EU-ODA. This table replicates Model (2) and Model (3) of Table 6 by restricting the sample to three different time periods in our analysis, 3, 5, and 7 years before and after EU-ODA. Model (1) to Model (3) restrict samples to investments made in early round only and report the Table 6 results with the alternative sample periods, while Model (4) to (6) repeat the process with investments made in late rounds only. Results remain consistent. We also report here the coefficient estimates for our full set of fixed effects at the technology category and year level. In addition this table reports coefficient estimates for all our controls in the baseline specification. Standard errors are clustered at the investing firm level. ${ }^{*} \mathrm{p}<0.10 ;{ }^{* *} \mathrm{p}<0.05 ;{ }^{* * *} \mathrm{p}<0.01$.

\begin{tabular}{|c|c|c|c|c|c|c|}
\hline & \multicolumn{6}{|c|}{ Dependent variables } \\
\hline & \multicolumn{6}{|c|}{ Number of investors } \\
\hline & \multicolumn{3}{|c|}{ Early-stage } & \multicolumn{3}{|c|}{ Late-stage } \\
\hline & $\begin{array}{c}3 \text { years } \\
(1)\end{array}$ & $\begin{array}{c}5 \text { years } \\
\text { (2) }\end{array}$ & $\begin{array}{c}7 \text { years } \\
\text { (3) }\end{array}$ & $\begin{array}{c}3 \text { years } \\
\text { (4) }\end{array}$ & $\begin{array}{c}5 \text { years } \\
(5)\end{array}$ & $\begin{array}{c}7 \text { years } \\
(6)\end{array}$ \\
\hline Drug & $\begin{array}{c}0.386 \\
(0.357)\end{array}$ & $\begin{array}{c}0.382 \\
(0.277)\end{array}$ & $\begin{array}{l}0.528^{*} \\
(0.285)\end{array}$ & $\begin{array}{l}0.912^{* * * *} \\
(0.265)\end{array}$ & $\begin{array}{l}0.665^{\text {**** }} \\
(0.235)\end{array}$ & $\begin{array}{l}0.717^{* * * *} \\
(0.219)\end{array}$ \\
\hline After ODA & $\begin{array}{l}0.862^{* *} \\
(0.439)\end{array}$ & $\begin{array}{c}1.466^{* * *} \\
(0.386)\end{array}$ & $\begin{array}{c}0.084 \\
(0.411)\end{array}$ & $\begin{array}{c}0.108 \\
(0.310)\end{array}$ & $\begin{array}{c}0.272 \\
(0.333)\end{array}$ & $\begin{array}{c}0.521 \\
(0.410)\end{array}$ \\
\hline $\begin{array}{c}\text { Drug-related } \\
* \text { After ODA }\end{array}$ & $44^{* * *}$ & $-0.515^{*}$ & -0.461 & $0.470^{*}$ & $0.719^{* * *}$ & $0.719^{* * *}$ \\
\hline & $(0.362)$ & $(0.305)$ & $(0.285)$ & $(0.268)$ & $(0.227)$ & $(0.211)$ \\
\hline EU startups & $\begin{array}{l}-0.877 \\
(0.827)\end{array}$ & $\begin{array}{l}-0.103 \\
(0.572)\end{array}$ & $\begin{array}{c}0.005 \\
(0.429)\end{array}$ & $\begin{array}{l}-0.318 \\
(0.603)\end{array}$ & $\begin{array}{l}-0.117 \\
(0.455)\end{array}$ & $\begin{array}{c}0.029 \\
(0.354)\end{array}$ \\
\hline US startups & $\begin{array}{l}-0.530 \\
(0.790)\end{array}$ & $\begin{array}{c}0.114 \\
(0.528)\end{array}$ & $\begin{array}{c}0.485 \\
(0.390)\end{array}$ & $\begin{array}{c}2.059^{* * * *} \\
(0.540)\end{array}$ & $\begin{array}{l}1.799^{* * * *} \\
(0.408)\end{array}$ & $\begin{array}{c}2.064^{* * *} \\
(0.317)\end{array}$ \\
\hline Biose & $\begin{array}{l}-0.798 \\
(0.872)\end{array}$ & $\begin{array}{c}0.219 \\
(0.606)\end{array}$ & $\begin{array}{c}0.185 \\
(0.553)\end{array}$ & $\begin{array}{l}-0.835 \\
(0.604)\end{array}$ & $\begin{array}{c}0.130 \\
(0.400)\end{array}$ & $\begin{array}{l}0.855^{* *} \\
(0.400)\end{array}$ \\
\hline Biotech Eq & $\begin{array}{l}-0.067 \\
(0.545)\end{array}$ & $\begin{array}{c}0.220 \\
(0.423)\end{array}$ & $\begin{array}{l}-0.027 \\
(0.405)\end{array}$ & $\begin{array}{l}1.276^{* * *} \\
(0.356)\end{array}$ & $\begin{array}{l}1.158^{* * *} \\
(0.286)\end{array}$ & $\begin{array}{l}1.521^{* * * *} \\
(0.292)\end{array}$ \\
\hline Biote & $\begin{array}{l}-0.367 \\
(0.567)\end{array}$ & $\begin{array}{l}-0.032 \\
(0.486)\end{array}$ & $\begin{array}{l}-0.092 \\
(0.486)\end{array}$ & $\begin{array}{l}-0.470 \\
(0.713)\end{array}$ & $\begin{array}{l}-0.215 \\
(1.003)\end{array}$ & $\begin{array}{l}-0.059 \\
(0.891)\end{array}$ \\
\hline Biotech $\mathbf{R}$ & $\begin{array}{c}0.824 \\
(0.639)\end{array}$ & $\begin{array}{l}1.187^{* *} \\
(0.476)\end{array}$ & $\begin{array}{l}1.088^{* * *} \\
(0.428)\end{array}$ & $\begin{array}{l}1.811^{* * * *} \\
(0.323)\end{array}$ & $\begin{array}{l}2.248^{* * * *} \\
(0.262)\end{array}$ & $\begin{array}{c}2.230^{* * * *} \\
(0.256)\end{array}$ \\
\hline Biotec & $\begin{array}{c}0.684 \\
(0.586)\end{array}$ & $\begin{array}{l}0.999^{*} \\
(0.524)\end{array}$ & $\begin{array}{l}1.116^{* *} \\
(0.519)\end{array}$ & $\begin{array}{l}1.472^{* * * *} \\
(0.561)\end{array}$ & $\begin{array}{l}1.292^{* * *} \\
(0.426)\end{array}$ & $\begin{array}{l}1.776^{* * * *} \\
(0.451)\end{array}$ \\
\hline Biotech-Industrial & $\begin{array}{l}-0.066 \\
(0.667)\end{array}$ & $\begin{array}{c}0.244 \\
(0.487)\end{array}$ & $\begin{array}{c}0.261 \\
(0.414)\end{array}$ & $\begin{array}{c}2.100^{* * * *} \\
(0.558)\end{array}$ & $\begin{array}{l}1.382^{* * *} \\
(0.448)\end{array}$ & $\begin{array}{l}1.384^{* * * *} \\
(0.353)\end{array}$ \\
\hline Biotech-Human & $\begin{array}{c}0.738^{* * *} \\
(0.210)\end{array}$ & $\begin{array}{c}0.858^{* * *} \\
(0.172)\end{array}$ & $\begin{array}{c}0.850^{* * *} \\
(0.144)\end{array}$ & $\begin{array}{l}1.686^{* * *} \\
(0.215)\end{array}$ & $\begin{array}{l}1.522^{* * *} \\
(0.159)\end{array}$ & $\begin{array}{l}1.447^{* * *} \\
(0.134)\end{array}$ \\
\hline Med/Health Products & $\begin{array}{c}0.320 \\
(0.361)\end{array}$ & $\begin{array}{l}0.382^{*} \\
(0.228)\end{array}$ & $\begin{array}{c}0.023 \\
(0.195)\end{array}$ & $\begin{array}{c}0.328 \\
(0.294)\end{array}$ & $\begin{array}{c}0.217 \\
(0.215)\end{array}$ & $\begin{array}{c}0.190 \\
(0.185)\end{array}$ \\
\hline
\end{tabular}




\begin{tabular}{|c|c|c|c|c|c|c|}
\hline Pharmaceutical & $\begin{array}{l}0.510^{* *} \\
(0.217)\end{array}$ & $\begin{array}{c}0.652^{* * *} \\
(0.171)\end{array}$ & $\begin{array}{l}0.504^{* * *} \\
(0.141)\end{array}$ & $\begin{array}{c}0.937^{* * *} \\
(0.268)\end{array}$ & $\begin{array}{l}1.041^{* * *} \\
(0.172)\end{array}$ & $\begin{array}{l}1.029^{* * * *} \\
(0.147)\end{array}$ \\
\hline 1994 & & & $\begin{array}{l}1.259^{* * *} \\
(0.406)\end{array}$ & & & $\begin{array}{c}0.179 \\
(0.321)\end{array}$ \\
\hline 1995 & & & $\begin{array}{l}-0.782^{* *} \\
(0.325)\end{array}$ & & & $\begin{array}{c}0.229 \\
(0.349)\end{array}$ \\
\hline 1996 & & $\begin{array}{c}0.032 \\
(0.283)\end{array}$ & $\begin{array}{l}-0.758^{* *} \\
(0.297)\end{array}$ & & $\begin{array}{c}-0.628^{* * *} \\
(0.238)\end{array}$ & $\begin{array}{l}-0.408 \\
(0.332)\end{array}$ \\
\hline 1997 & & $\begin{array}{c}0.124 \\
(0.262)\end{array}$ & $\begin{array}{c}-0.847^{* * *} \\
(0.314)\end{array}$ & & $\begin{array}{c}0.452 \\
(0.303)\end{array}$ & $\begin{array}{l}0.702^{*} \\
(0.364)\end{array}$ \\
\hline 1998 & $\begin{array}{l}-0.246 \\
(0.274)\end{array}$ & $\begin{array}{l}-0.083 \\
(0.270)\end{array}$ & $\begin{array}{c}-1.047^{* * *} \\
(0.315)\end{array}$ & $\begin{array}{c}0.075 \\
(0.215)\end{array}$ & $\begin{array}{c}0.462 \\
(0.302)\end{array}$ & $\begin{array}{l}0.630^{*} \\
(0.364)\end{array}$ \\
\hline 1999 & $\begin{array}{l}-0.271 \\
(0.296)\end{array}$ & $\begin{array}{l}-0.090 \\
(0.281)\end{array}$ & $\begin{array}{c}-0.969^{* * *} \\
(0.289)\end{array}$ & $\begin{array}{c}-0.619^{* * *} \\
(0.207)\end{array}$ & $\begin{array}{l}-0.215 \\
(0.284)\end{array}$ & $\begin{array}{l}-0.009 \\
(0.355)\end{array}$ \\
\hline 2000 & $\begin{array}{l}-0.008 \\
(0.255)\end{array}$ & $\begin{array}{c}-0.812^{* * *} \\
(0.228)\end{array}$ & $\begin{array}{l}-0.456 \\
(0.285)\end{array}$ & $\begin{array}{l}-0.321 \\
(0.214)\end{array}$ & $\begin{array}{l}-0.296 \\
(0.186)\end{array}$ & $\begin{array}{l}-0.350^{*} \\
(0.203)\end{array}$ \\
\hline 2001 & $\begin{array}{l}0.427^{*} \\
(0.241)\end{array}$ & $\begin{array}{c}-0.398^{* *} \\
(0.201)\end{array}$ & $\begin{array}{c}0.002 \\
(0.263)\end{array}$ & $\begin{array}{c}0.352^{*} \\
(0.195)\end{array}$ & $\begin{array}{l}0.344^{*} \\
(0.207)\end{array}$ & $\begin{array}{c}0.283 \\
(0.205)\end{array}$ \\
\hline 2002 & $\begin{array}{l}0.486^{* *} \\
(0.189)\end{array}$ & $\begin{array}{l}-0.357^{* *} \\
(0.175)\end{array}$ & $\begin{array}{c}0.117 \\
(0.257)\end{array}$ & $\begin{array}{l}0.346^{*} \\
(0.210)\end{array}$ & $\begin{array}{c}0.299 \\
(0.186)\end{array}$ & $\begin{array}{c}0.227 \\
(0.194)\end{array}$ \\
\hline 2003 & & $\begin{array}{c}-0.764^{* * *} \\
(0.189)\end{array}$ & $\begin{array}{l}-0.261 \\
(0.248)\end{array}$ & & $\begin{array}{l}-0.016 \\
(0.192)\end{array}$ & $\begin{array}{l}-0.098 \\
(0.171)\end{array}$ \\
\hline 2004 & & $\begin{array}{c}-0.555^{* * *} \\
(0.187)\end{array}$ & $\begin{array}{l}-0.167 \\
(0.211)\end{array}$ & & $\begin{array}{c}0.003 \\
(0.141)\end{array}$ & $\begin{array}{l}-0.050 \\
(0.158)\end{array}$ \\
\hline 2005 & & & $\begin{array}{c}0.300 \\
(0.207)\end{array}$ & & & $\begin{array}{l}-0.060 \\
(0.146)\end{array}$ \\
\hline 2006 & & & $\begin{array}{c}-0.370^{* *} \\
(0.172)\end{array}$ & & & $\begin{array}{c}-0.142 \\
(0.147)\end{array}$ \\
\hline Observations & 2,987 & 4,475 & 6,019 & 8,431 & 13,354 & 18,046 \\
\hline $\mathbf{R}^{2}$ & 0.400 & 0.388 & 0.378 & 0.367 & 0.360 & 0.356 \\
\hline
\end{tabular}


Appendix Table 10. Changes in the Invested Amount After EU-ODA - Results with All Controls. This table replicates Table 7 reporting the coefficient estimates for our full set of fixed effects at the technology category and year level. In addition this table reports coefficient estimates for all our controls in the baseline specification. Standard errors are clustered at the investee firm level. ${ }^{*} \mathrm{p}<0.10 ;{ }^{* *} \mathrm{p}<0.05 ;{ }^{* * *} \mathrm{p}<0.01$.

\begin{tabular}{cccc}
\hline & \multicolumn{3}{c}{ Dependent variables } \\
\cline { 2 - 4 } & \multicolumn{3}{c}{ Investment amount in a round $(\$ 1 \mathrm{~K})$} \\
& Total & Early-stage & Late-stage \\
& $(1)$ & $(2)$ & $(3)$ \\
\hline Drug-related & $2,145.008^{* * *}$ & $2,100.302^{* *}$ & $2,461.805^{* * *}$ \\
& $(393.253)$ & $(882.699)$ & $(515.129)$ \\
After ODA & $-4,268.836^{* * *}$ & $-2,301.149$ & $-3,338.689^{* * *}$ \\
Drug-related & $(691.035)$ & $(1,411.083)$ & $(999.937)$ \\
*After ODA & $791.456^{*}$ & $-1,153.093$ & $1,198.666^{* *}$ \\
EU startups & $(434.347)$ & $(923.312)$ & $(562.095)$ \\
& $-2,551.749^{* * *}$ & $-1,542.173^{* * *}$ & $-2,840.175^{* * *}$ \\
US startups & $(335.679)$ & $(673.601)$ & $(449.654)$ \\
1990 & 3.242 & $985.390^{*}$ & 525.338 \\
Biosensors & $(285.859)$ & $(560.646)$ & $(385.857)$ \\
Bharmaceutical & $4,130.691^{* * *}$ & $1,532.503$ & $5,093.397^{* * *}$ \\
Biotech Equipment & $(1,102.213)$ & $(1,752.065)$ & $(1,800.780)$ \\
Biotech-Industrial & $2,466.092^{* * *}$ & 783.661 & $3,924.986^{* * *}$ \\
& $(573.054)$ & $(1,222.967)$ & $(702.851)$ \\
Biotech Other & $1,511.043$ & $-2,302.838$ & $8,689.796^{* * *}$ \\
& $(1,598.675)$ & $(2,250.252)$ & $(2,114.508)$ \\
Biotech Research & $2,465.752^{* * *}$ & $1,130.974$ & $2,638.681^{* * *}$ \\
& $(513.270)$ & $(1,216.597)$ & $(663.861)$ \\
& $(751.110)$ & $(1,507.158)$ & $(1,111.633)$
\end{tabular}




\begin{tabular}{|c|c|c|c|}
\hline 1991 & $\begin{array}{l}-501.894 \\
(761.410)\end{array}$ & $\begin{array}{l}-3,907.433^{* *} \\
(1,634.098)\end{array}$ & $\begin{array}{c}106.906 \\
(1,126.514)\end{array}$ \\
\hline 1992 & $\begin{array}{c}161.047 \\
(710.295)\end{array}$ & $\begin{array}{l}-1,106.563 \\
(1,455.640)\end{array}$ & $\begin{array}{c}620.280 \\
(1,127.009)\end{array}$ \\
\hline 1993 & $\begin{array}{c}26.050 \\
(763.994)\end{array}$ & $\begin{array}{c}297.592 \\
(1,688.996)\end{array}$ & $\begin{array}{c}1,278.688 \\
(1,260.407)\end{array}$ \\
\hline 1994 & $\begin{array}{c}-1,575.864^{* *} \\
(731.730)\end{array}$ & $\begin{array}{c}-4,186.417^{* * *} \\
(1,611.474)\end{array}$ & $\begin{array}{c}-330.907 \\
(1,239.798)\end{array}$ \\
\hline 1995 & $\begin{array}{c}402.156 \\
(708.900)\end{array}$ & $\begin{array}{c}-491.687 \\
(1,449.368)\end{array}$ & $\begin{array}{c}223.699 \\
(1,146.634)\end{array}$ \\
\hline 1996 & $\begin{array}{l}-146.835 \\
(704.365)\end{array}$ & $\begin{array}{c}-117.901 \\
(1,374.477)\end{array}$ & $\begin{array}{c}1,060.302 \\
(1,077.165)\end{array}$ \\
\hline 1997 & $\begin{array}{l}-373.902 \\
(683.689)\end{array}$ & $\begin{array}{c}-737.847 \\
(1,295.385)\end{array}$ & $\begin{array}{c}576.656 \\
(1,049.093)\end{array}$ \\
\hline 1998 & $\begin{array}{l}-591.294 \\
(656.107)\end{array}$ & $\begin{array}{c}-921.102 \\
(1,272.635)\end{array}$ & $\begin{array}{c}490.243 \\
(1,000.655)\end{array}$ \\
\hline 1999 & $\begin{array}{c}36.978 \\
(655.700)\end{array}$ & $\begin{array}{c}-648.320 \\
(1,257.455)\end{array}$ & $\begin{array}{c}575.100 \\
(992.978)\end{array}$ \\
\hline 2000 & $\begin{array}{c}2,887.323^{* * *} \\
(439.056)\end{array}$ & $\begin{array}{c}2,493.977^{* * * *} \\
(835.192)\end{array}$ & $\begin{array}{c}2,571.430^{* * * *} \\
(597.481)\end{array}$ \\
\hline 2001 & $\begin{array}{c}3,351.524^{* * * *} \\
(451.270)\end{array}$ & $\begin{array}{c}2,105.606^{* *} \\
(915.413)\end{array}$ & $\begin{array}{c}2,895.344^{* * * *} \\
(595.397)\end{array}$ \\
\hline 2002 & $\begin{array}{c}2,367.244^{* * * *} \\
(459.838)\end{array}$ & $\begin{array}{l}1,425.656 \\
(932.880)\end{array}$ & $\begin{array}{c}1,525.599^{* *} \\
(603.084)\end{array}$ \\
\hline 2003 & $\begin{array}{c}1,231.415^{* * *} \\
(454.919)\end{array}$ & $\begin{array}{c}426.717 \\
(862.149)\end{array}$ & $\begin{array}{c}985.023 \\
(602.404)\end{array}$ \\
\hline 2004 & $\begin{array}{c}339.831 \\
(437.383)\end{array}$ & $\begin{array}{c}84.785 \\
(893.044)\end{array}$ & $\begin{array}{c}246.852 \\
(574.404)\end{array}$ \\
\hline 2005 & $\begin{array}{c}1,666.976^{* * *} \\
(427.560)\end{array}$ & $\begin{array}{c}1,922.833^{* *} \\
(882.805)\end{array}$ & $\begin{array}{c}616.192 \\
(551.043)\end{array}$ \\
\hline 2006 & $\begin{array}{c}2,337.128^{* * * *} \\
(420.867)\end{array}$ & $\begin{array}{l}1,343.976 \\
(860.437)\end{array}$ & $\begin{array}{c}1,278.055^{\text {*** }} \\
(567.027)\end{array}$ \\
\hline 2007 & $\begin{array}{c}1,055.060^{* * * *} \\
(398.707)\end{array}$ & $\begin{array}{c}847.146 \\
(809.494)\end{array}$ & $\begin{array}{c}-79.879 \\
(524.966)\end{array}$ \\
\hline 2008 & $\begin{array}{l}710.963^{*} \\
(404.000)\end{array}$ & $\begin{array}{c}986.504 \\
(821.430)\end{array}$ & $\begin{array}{l}-133.385 \\
(555.529)\end{array}$ \\
\hline 2009 & $\begin{array}{c}139.433 \\
(418.439)\end{array}$ & $\begin{array}{c}677.565 \\
(820.048)\end{array}$ & $\begin{array}{c}-68.125 \\
(584.446)\end{array}$ \\
\hline 2010 & $\begin{array}{c}-1,169.398^{* * *} \\
(394.863)\end{array}$ & $\begin{array}{l}-487.439 \\
(816.086)\end{array}$ & $\begin{array}{l}-493.488 \\
(553.834)\end{array}$ \\
\hline
\end{tabular}




\begin{tabular}{cccc} 
Constant & $\begin{array}{c}12,462.750^{* * *} \\
(676.400)\end{array}$ & $\begin{array}{c}(1,399.406) \\
\end{array}$ & $\begin{array}{c}(982.889) \\
\end{array}$ \\
\hline Observations & 20,386 & 4,399 & 10,479 \\
$\mathbf{R}^{\mathbf{2}}$ & 0.040 & 0.025 & 0.056 \\
\hline
\end{tabular}


Appendix Table 11. Exit Performance of Early-stage Startups - Results with All Controls. This table replicates Table 8 reporting the coefficient estimates for our full set of fixed effects at the technology category and year level. In addition this table reports coefficient estimates for all our controls in the baseline specification. Standard errors are clustered at the investing firm level. ${ }^{*} \mathrm{p}<0.10 ;{ }^{* *} \mathrm{p}<0.05 ;{ }^{* * *} \mathrm{p}<0.01$.

\begin{tabular}{|c|c|c|c|}
\hline & \multicolumn{3}{|c|}{ Dependent variables } \\
\hline & $\begin{array}{c}\text { M\&A } \\
\text { (1) }\end{array}$ & $\begin{array}{l}\text { IPO } \\
(2)\end{array}$ & $\begin{array}{c}\text { Bankruptcy } \\
\text { (3) }\end{array}$ \\
\hline Drug-related & $\begin{array}{c}0.043 \\
(0.073)\end{array}$ & $\begin{array}{l}-0.017 \\
(0.054)\end{array}$ & $\begin{array}{l}-0.093 \\
(0.074)\end{array}$ \\
\hline After ODA & $\begin{array}{c}0.086 \\
(0.076)\end{array}$ & $\begin{array}{c}-0.316^{* * *} \\
(0.070)\end{array}$ & $\begin{array}{l}-0.139^{* *} \\
(0.066)\end{array}$ \\
\hline $\begin{array}{l}\text { Drug-related } \\
\text { *After ODA }\end{array}$ & $\begin{array}{l}-0.132^{*} \\
(0.068)\end{array}$ & $\begin{array}{l}0.136^{* *} \\
(0.053)\end{array}$ & $\begin{array}{l}0.020 \\
(0.062)\end{array}$ \\
\hline EU startups & $\begin{array}{c}0.102 \\
(0.108)\end{array}$ & $\begin{array}{l}-0.086 \\
(0.121)\end{array}$ & $\begin{array}{c}0.101 \\
(0.111)\end{array}$ \\
\hline US startups & $\begin{array}{c}0.100 \\
(0.097)\end{array}$ & $\begin{array}{c}-0.107 \\
(0.110)\end{array}$ & $\begin{array}{c}0.118 \\
(0.106)\end{array}$ \\
\hline Biosensors & $\begin{array}{c}0.134 \\
(0.185)\end{array}$ & $\begin{array}{l}-0.093 \\
(0.083)\end{array}$ & $\begin{array}{l}-0.137 \\
(0.091)\end{array}$ \\
\hline Biotech Equipment & $\begin{array}{c}0.051 \\
(0.100)\end{array}$ & $\begin{array}{c}0.103 \\
(0.065)\end{array}$ & $\begin{array}{l}-0.137^{*} \\
(0.082)\end{array}$ \\
\hline Biotech Other & $\begin{array}{l}-0.092 \\
(0.128)\end{array}$ & $\begin{array}{c}0.044 \\
(0.075)\end{array}$ & $\begin{array}{c}0.092 \\
(0.161)\end{array}$ \\
\hline Biotech Research & $\begin{array}{l}-0.109 \\
(0.107)\end{array}$ & $\begin{array}{c}0.010 \\
(0.059)\end{array}$ & $\begin{array}{l}-0.003 \\
(0.092)\end{array}$ \\
\hline Biotech-Animal & $\begin{array}{l}-0.066 \\
(0.115)\end{array}$ & $\begin{array}{l}0.239^{* *} \\
(0.101)\end{array}$ & $\begin{array}{l}-0.016 \\
(0.102)\end{array}$ \\
\hline Biotech-Industrial & $\begin{array}{l}-0.114 \\
(0.103)\end{array}$ & $\begin{array}{l}0.298^{* * *} \\
(0.092)\end{array}$ & $\begin{array}{l}-0.181^{* *} \\
(0.072)\end{array}$ \\
\hline Biotech-Human & $\begin{array}{l}-0.003 \\
(0.035)\end{array}$ & $\begin{array}{l}0.139^{* * *} \\
(0.036)\end{array}$ & $\begin{array}{c}-0.076^{* * *} \\
(0.026)\end{array}$ \\
\hline Med/Health Products & $\begin{array}{l}-0.057 \\
(0.061)\end{array}$ & $\begin{array}{c}0.035 \\
(0.069)\end{array}$ & $\begin{array}{c}0.045 \\
(0.054)\end{array}$ \\
\hline Pharmaceutical & $\begin{array}{l}0.099^{* *} \\
(0.040)\end{array}$ & $\begin{array}{c}0.050 \\
(0.039)\end{array}$ & $\begin{array}{l}-0.032 \\
(0.031)\end{array}$ \\
\hline 1997 & $\begin{array}{l}0.127^{* *} \\
(0.050)\end{array}$ & $\begin{array}{c}-0.220^{* * * *} \\
(0.051)\end{array}$ & $\begin{array}{c}0.068 \\
(0.047)\end{array}$ \\
\hline 1998 & $\begin{array}{c}0.003 \\
(0.053)\end{array}$ & $\begin{array}{l}-0.118^{* *} \\
(0.060)\end{array}$ & $\begin{array}{l}-0.006 \\
(0.049)\end{array}$ \\
\hline
\end{tabular}




\begin{tabular}{cccc}
1999 & $0.192^{* * *}$ & $-0.279^{* * *}$ & 0.022 \\
& $(0.055)$ & $(0.053)$ & $(0.055)$ \\
$\mathbf{2 0 0 0}$ & $0.085^{* *}$ & -0.007 & $0.106^{* * *}$ \\
& $(0.040)$ & $(0.035)$ & $(0.029)$ \\
$\mathbf{2 0 0 1}$ & 0.027 & -0.043 & $0.075^{* * *}$ \\
& $(0.042)$ & $(0.035)$ & $(0.024)$ \\
$\mathbf{2 0 0 2}$ & 0.007 & 0.010 & $0.048^{* * *}$ \\
& $(0.040)$ & $(0.034)$ & $(0.021)$ \\
$\mathbf{2 0 0 3}$ & 0.0002 & -0.012 & $0.057^{* * *}$ \\
& $(0.037)$ & $(0.034)$ & $(0.020)$ \\
$\mathbf{2 0 0 4}$ & 0.001 & 0.023 & 0.021 \\
& $(0.034)$ & $(0.027)$ & $(0.019)$ \\
\hline Observations & 4,291 & 4,291 & 4,291 \\
$\mathbf{R}^{2}$ & 0.331 & 0.346 & 0.296 \\
\hline
\end{tabular}


Appendix Table 12. Exit performance of early-stage startups given Alternative Time Periods Before/After EU-ODA. This table replicates Table 8 by restricting the sample to two different time periods in our analysis, 3 and 7 years before and after EU-ODA. We also report here the coefficient estimates for our full set of fixed effects at the technology category and year level. In addition this table reports coefficient estimates for all our controls in the baseline specification. Standard errors are clustered at the investing firm level. ${ }^{*} \mathrm{p}<0.10 ;{ }^{* *} \mathrm{p}<0.05 ;{ }^{* * *} \mathrm{p}<0.01$.

\begin{tabular}{|c|c|c|c|c|c|c|}
\hline & \multicolumn{6}{|c|}{ Dependent variables } \\
\hline & $\begin{array}{l}\mathrm{M} \& \mathrm{~A} \\
(1)\end{array}$ & $\begin{array}{l}\text { IPO } \\
(2)\end{array}$ & $\begin{array}{c}\text { Bankruptcy } \\
\text { (3) }\end{array}$ & $\begin{array}{c}M \& A \\
(4)\end{array}$ & $\begin{array}{l}\text { IPO } \\
(5)\end{array}$ & $\begin{array}{c}\text { Bankruptcy } \\
\text { (6) }\end{array}$ \\
\hline & \multicolumn{3}{|c|}{$\begin{array}{c}3 \text { years } \\
\text { Before and after }\end{array}$} & \multicolumn{3}{|c|}{$\begin{array}{c}7 \text { years } \\
\text { Before and after }\end{array}$} \\
\hline \multirow[t]{2}{*}{ Drug-related } & -0.010 & 0.035 & -0.086 & 0.054 & -0.063 & -0.091 \\
\hline & $(0.099)$ & $(0.066)$ & $(0.089)$ & $(0.068)$ & $(0.051)$ & $(0.057)$ \\
\hline \multirow[t]{2}{*}{ After ODA } & -0.057 & -0.074 & $-0.153^{* *}$ & -0.043 & $-0.288^{* * *}$ & -0.046 \\
\hline & $(0.082)$ & $(0.061)$ & $(0.076)$ & $(0.087)$ & $(0.075)$ & $(0.056)$ \\
\hline \multirow[t]{2}{*}{$\begin{array}{c}\text { Drug-related } \\
* \text { After ODA }\end{array}$} & -0.096 & $0.111^{*}$ & 0.036 & $-0.145^{* *}$ & $0.161^{* * *}$ & 0.003 \\
\hline & $(0.083)$ & $(0.060)$ & $(0.073)$ & $(0.063)$ & $(0.045)$ & $(0.052)$ \\
\hline \multirow[t]{2}{*}{ EU startups } & 0.119 & -0.148 & $0.236^{*}$ & 0.107 & -0.100 & 0.067 \\
\hline & $(0.113)$ & $(0.162)$ & $(0.135)$ & $(0.083)$ & $(0.088)$ & $(0.089)$ \\
\hline \multirow[t]{2}{*}{ US startups } & $0.198^{*}$ & -0.207 & $0.254^{*}$ & 0.085 & -0.071 & 0.088 \\
\hline & $(0.103)$ & $(0.155)$ & $(0.132)$ & $(0.077)$ & $(0.079)$ & $(0.084)$ \\
\hline \multirow[t]{2}{*}{ Biosensors } & 0.009 & 0.063 & $-0.186^{* *}$ & -0.052 & -0.089 & $-0.116^{*}$ \\
\hline & $(0.246)$ & $(0.092)$ & $(0.091)$ & $(0.166)$ & $(0.074)$ & $(0.069)$ \\
\hline \multirow[t]{2}{*}{ Biotech Equipment } & 0.054 & 0.054 & -0.110 & 0.059 & 0.042 & $-0.136^{*}$ \\
\hline & $(0.132)$ & $(0.074)$ & $(0.101)$ & $(0.087)$ & $(0.058)$ & $(0.070)$ \\
\hline \multirow[t]{2}{*}{ Biotech Other } & -0.197 & 0.078 & 0.165 & -0.080 & 0.017 & 0.029 \\
\hline & $(0.161)$ & $(0.091)$ & $(0.203)$ & $(0.111)$ & $(0.065)$ & $(0.147)$ \\
\hline \multirow[t]{2}{*}{ Biotech Research } & -0.175 & 0.050 & 0.019 & -0.086 & -0.021 & -0.006 \\
\hline & $(0.137)$ & $(0.069)$ & $(0.119)$ & $(0.095)$ & $(0.057)$ & $(0.076)$ \\
\hline \multirow[t]{2}{*}{ Biotech-Animal } & -0.114 & $0.279^{* *}$ & -0.023 & -0.039 & $0.214^{* *}$ & -0.025 \\
\hline & $(0.145)$ & $(0.120)$ & $(0.121)$ & $(0.103)$ & $(0.092)$ & $(0.090)$ \\
\hline \multirow[t]{2}{*}{ Biotech-Industrial } & $-0.254^{*}$ & $0.515^{* * *}$ & $-0.195^{*}$ & -0.082 & $0.215^{* * *}$ & $-0.171^{* * *}$ \\
\hline & $(0.137)$ & $(0.124)$ & $(0.103)$ & $(0.089)$ & $(0.074)$ & $(0.058)$ \\
\hline \multirow[t]{2}{*}{ Biotech-Human } & -0.025 & $0.125^{* * *}$ & $-0.089^{* *}$ & 0.022 & $0.106^{* * *}$ & $-0.048^{* * *}$ \\
\hline & $(0.042)$ & $(0.041)$ & $(0.037)$ & $(0.027)$ & $(0.025)$ & $(0.018)$ \\
\hline \multirow[t]{2}{*}{ Med/Health Products } & -0.071 & 0.082 & 0.036 & -0.041 & -0.002 & 0.066 \\
\hline & $(0.075)$ & $(0.091)$ & $(0.070)$ & $(0.047)$ & $(0.050)$ & $(0.041)$ \\
\hline \multirow[t]{2}{*}{ Pharmaceutical } & 0.066 & 0.002 & -0.043 & $0.069^{* *}$ & $0.065^{* *}$ & -0.029 \\
\hline & $(0.050)$ & $(0.040)$ & $(0.040)$ & $(0.034)$ & $(0.033)$ & $(0.023)$ \\
\hline 1994 & & & & -0.052 & 0.011 & $0.073^{*}$ \\
\hline
\end{tabular}




\begin{tabular}{|c|c|c|c|c|c|c|}
\hline & & & & $(0.072)$ & $(0.071)$ & $(0.042)$ \\
\hline 1995 & & & & $\begin{array}{l}-0.114 \\
(0.073)\end{array}$ & $\begin{array}{l}0.165^{* *} \\
(0.074)\end{array}$ & $\begin{array}{l}0.078^{*} \\
(0.047)\end{array}$ \\
\hline 1996 & & & & $\begin{array}{l}-0.097 \\
(0.070)\end{array}$ & $\begin{array}{c}0.110 \\
(0.075)\end{array}$ & $\begin{array}{l}0.094^{* *} \\
(0.045)\end{array}$ \\
\hline 1997 & & & & $\begin{array}{c}0.027 \\
(0.066)\end{array}$ & $\begin{array}{l}-0.114^{*} \\
(0.064)\end{array}$ & $\begin{array}{c}0.161^{* * * *} \\
(0.042)\end{array}$ \\
\hline 1998 & $\begin{array}{c}-0.127^{\text {***k }} \\
(0.047)\end{array}$ & $\begin{array}{l}0.111^{* *} \\
(0.044)\end{array}$ & $\begin{array}{l}-0.066^{*} \\
(0.039)\end{array}$ & $\begin{array}{l}-0.102 \\
(0.069)\end{array}$ & $\begin{array}{l}-0.012 \\
(0.065)\end{array}$ & $\begin{array}{l}0.088^{* *} \\
(0.044)\end{array}$ \\
\hline 1999 & $\begin{array}{c}0.073 \\
(0.050)\end{array}$ & $\begin{array}{l}-0.060^{*} \\
(0.036)\end{array}$ & $\begin{array}{l}-0.042 \\
(0.043)\end{array}$ & $\begin{array}{c}0.079 \\
(0.065)\end{array}$ & $\begin{array}{c}-0.161^{* * *} \\
(0.057)\end{array}$ & $\begin{array}{l}0.114^{* *} \\
(0.044)\end{array}$ \\
\hline 2000 & $\begin{array}{l}0.079^{*} \\
(0.048)\end{array}$ & $\begin{array}{l}-0.010 \\
(0.032)\end{array}$ & $\begin{array}{c}0.043 \\
(0.028)\end{array}$ & $\begin{array}{c}0.114^{* * *} \\
(0.040)\end{array}$ & $\begin{array}{l}0.063^{* *} \\
(0.031)\end{array}$ & $\begin{array}{c}0.116^{* * * *} \\
(0.026)\end{array}$ \\
\hline 2001 & $\begin{array}{c}0.019 \\
(0.050)\end{array}$ & $\begin{array}{l}-0.036 \\
(0.030)\end{array}$ & $\begin{array}{c}0.016 \\
(0.026)\end{array}$ & $\begin{array}{c}0.056 \\
(0.040)\end{array}$ & $\begin{array}{c}0.028 \\
(0.033)\end{array}$ & $\begin{array}{c}0.089^{* * * *} \\
(0.021)\end{array}$ \\
\hline 2002 & & & & $\begin{array}{c}0.039 \\
(0.043)\end{array}$ & $\begin{array}{l}0.084^{* *} \\
(0.034)\end{array}$ & $\begin{array}{c}0.060^{* * * *} \\
(0.023)\end{array}$ \\
\hline 2003 & & & & $\begin{array}{c}0.033 \\
(0.042)\end{array}$ & $\begin{array}{l}0.070^{* *} \\
(0.033)\end{array}$ & $\begin{array}{c}0.064^{* * * *} \\
(0.020)\end{array}$ \\
\hline 2004 & & & & $\begin{array}{c}0.041 \\
(0.036)\end{array}$ & $\begin{array}{c}0.089^{* * * *} \\
(0.027)\end{array}$ & $\begin{array}{l}0.031^{*} \\
(0.018)\end{array}$ \\
\hline 2005 & & & & $\begin{array}{c}0.037 \\
(0.030)\end{array}$ & $\begin{array}{l}0.065^{* *} \\
(0.029)\end{array}$ & $\begin{array}{c}0.007 \\
(0.015)\end{array}$ \\
\hline 2006 & & & & $\begin{array}{c}-0.081^{* * *} \\
(0.027)\end{array}$ & $\begin{array}{l}0.086^{* * * *} \\
(0.030)\end{array}$ & $\begin{array}{l}-0.002 \\
(0.012)\end{array}$ \\
\hline Observations & 2,987 & 2,987 & 2,987 & 6,019 & 6,019 & 6,019 \\
\hline $\mathbf{R}^{2}$ & 0.364 & 0.379 & 0.315 & 0.309 & 0.315 & 0.291 \\
\hline
\end{tabular}


Appendix Table 13. Replication of Table 8 with multinomial logit regressions. We report here Table 8 results with multinomial logit models, taking into account that the dependent variable is binary. We also report here the coefficient estimates for our full set of fixed effects at the technology category and year level. In addition this table reports coefficient estimates for all our controls in the baseline specification. Standard errors are clustered at the investing firm level. $* \mathrm{p}<0.10 ;{ }^{* *} \mathrm{p}<0.05 ;{ }^{* * *} \mathrm{p}<0.01$

\begin{tabular}{|c|c|c|c|}
\hline & \multicolumn{3}{|c|}{ Dependent variables } \\
\hline & $\begin{array}{c}\text { M\&A } \\
\text { (1) }\end{array}$ & $\begin{array}{l}\text { IPO } \\
(2)\end{array}$ & $\begin{array}{c}\text { Bankruptcy } \\
\text { (3) }\end{array}$ \\
\hline Drug-related & $\begin{array}{c}0.069 \\
(0.176)\end{array}$ & $\begin{array}{c}0.122 \\
(0.260)\end{array}$ & $\begin{array}{l}-0.383^{*} \\
(0.200)\end{array}$ \\
\hline After ODA & $\begin{array}{c}0.333 \\
(0.232)\end{array}$ & $\begin{array}{c}-2.649^{* * *} \\
(0.312)\end{array}$ & $\begin{array}{c}-2.148^{* * *} \\
(0.346)\end{array}$ \\
\hline $\begin{array}{l}\text { Drug-related } \\
\text { *After ODA }\end{array}$ & $\begin{array}{c}-0.491^{* * *} \\
(0.184)\end{array}$ & $\begin{array}{l}1.557^{* * *} \\
(0.275)\end{array}$ & $\begin{array}{c}0.337 \\
(0.245)\end{array}$ \\
\hline EU startups & $\begin{array}{l}1.423^{* * *} \\
(0.251)\end{array}$ & $\begin{array}{c}-0.526^{* * *} \\
(0.203)\end{array}$ & $\begin{array}{l}1.158^{* * * *} \\
(0.400)\end{array}$ \\
\hline US startups & $\begin{array}{l}1.612^{* * *} \\
(0.242)\end{array}$ & $\begin{array}{c}-0.568^{* * *} \\
(0.188)\end{array}$ & $\begin{array}{l}1.362^{* * * *} \\
(0.383)\end{array}$ \\
\hline IVC & $\begin{array}{l}-0.023 \\
(0.193)\end{array}$ & $\begin{array}{c}0.398 \\
(0.249)\end{array}$ & $\begin{array}{c}0.063 \\
(0.292)\end{array}$ \\
\hline CVC & $\begin{array}{c}0.041 \\
(0.235)\end{array}$ & $\begin{array}{c}0.244 \\
(0.294)\end{array}$ & $\begin{array}{l}-0.277 \\
(0.376)\end{array}$ \\
\hline Angel & $\begin{array}{c}0.317 \\
(0.500)\end{array}$ & $\begin{array}{c}-14.702 \\
(505.544)\end{array}$ & $\begin{array}{l}-0.872 \\
(1.084)\end{array}$ \\
\hline GVC & $\begin{array}{l}-0.398 \\
(0.863)\end{array}$ & $\begin{array}{c}-14.342 \\
(787.739)\end{array}$ & $\begin{array}{c}0.417 \\
(1.175)\end{array}$ \\
\hline Biosensors & $\begin{array}{l}-0.527 \\
(0.390)\end{array}$ & $\begin{array}{c}-13.629 \\
(352.373)\end{array}$ & $\begin{array}{l}-1.813^{*} \\
(1.037)\end{array}$ \\
\hline Biotech Equipment & $\begin{array}{c}0.046 \\
(0.230)\end{array}$ & $\begin{array}{l}1.279^{* * *} \\
(0.360)\end{array}$ & $\begin{array}{l}-0.734^{* *} \\
(0.345)\end{array}$ \\
\hline Biotech Other & $\begin{array}{l}-1.037 \\
(0.660)\end{array}$ & $\begin{array}{c}-13.075 \\
(486.237)\end{array}$ & $\begin{array}{l}1.561^{* * * *} \\
(0.576)\end{array}$ \\
\hline Biotech Research & $\begin{array}{c}-0.635^{* * * *} \\
(0.215)\end{array}$ & $\begin{array}{c}0.307 \\
(0.407)\end{array}$ & $\begin{array}{c}0.247 \\
(0.262)\end{array}$ \\
\hline Biotech-Animal & $\begin{array}{l}-0.110 \\
(0.238)\end{array}$ & $\begin{array}{l}1.822^{* * * *} \\
(0.337)\end{array}$ & $\begin{array}{l}-0.266 \\
(0.313)\end{array}$ \\
\hline Biotech-Industrial & $\begin{array}{c}-1.176^{* * *} \\
(0.380)\end{array}$ & $\begin{array}{l}1.962^{* * * *} \\
(0.439)\end{array}$ & $\begin{array}{l}-2.283^{* *} \\
(1.031)\end{array}$ \\
\hline
\end{tabular}




\begin{tabular}{|c|c|c|c|}
\hline Biotech-Human & $\begin{array}{l}-0.129 \\
(0.089)\end{array}$ & $\begin{array}{l}1.076^{* * *} \\
(0.113)\end{array}$ & $\begin{array}{c}-0.660^{* * *} \\
(0.137)\end{array}$ \\
\hline Med/Health Products & $\begin{array}{l}-0.241 \\
(0.150)\end{array}$ & $\begin{array}{c}0.054 \\
(0.213)\end{array}$ & $\begin{array}{l}0.370^{* * *} \\
(0.182)\end{array}$ \\
\hline Pharmaceutical & $\begin{array}{c}0.292^{* * *} \\
(0.106)\end{array}$ & $\begin{array}{c}0.682^{* * *} \\
(0.137)\end{array}$ & $\begin{array}{l}-0.217 \\
(0.159)\end{array}$ \\
\hline 1997 & $\begin{array}{l}0.522^{* * *} \\
(0.196)\end{array}$ & $\begin{array}{c}-1.300^{* * *} \\
(0.229)\end{array}$ & $\begin{array}{c}0.251 \\
(0.223)\end{array}$ \\
\hline 1998 & $\begin{array}{l}-0.108 \\
(0.197)\end{array}$ & $\begin{array}{c}-0.599^{* * *} \\
(0.204)\end{array}$ & $\begin{array}{l}-0.056 \\
(0.229)\end{array}$ \\
\hline 1999 & $\begin{array}{l}0.786^{* * *} \\
(0.190)\end{array}$ & $\begin{array}{c}-1.755^{* * *} \\
(0.233)\end{array}$ & $\begin{array}{l}-0.019 \\
(0.224)\end{array}$ \\
\hline 2000 & $\begin{array}{l}0.364^{* * *} \\
(0.130)\end{array}$ & $\begin{array}{l}-0.024 \\
(0.157)\end{array}$ & $\begin{array}{l}1.550^{* * *} \\
(0.254)\end{array}$ \\
\hline 2001 & $\begin{array}{l}0.244^{*} \\
(0.137)\end{array}$ & $\begin{array}{l}-0.233 \\
(0.174)\end{array}$ & $\begin{array}{l}1.228^{* * * *} \\
(0.269)\end{array}$ \\
\hline 2002 & $\begin{array}{c}0.089 \\
(0.138)\end{array}$ & $\begin{array}{c}0.139 \\
(0.163)\end{array}$ & $\begin{array}{l}0.939^{* * *} \\
(0.279)\end{array}$ \\
\hline 2003 & $\begin{array}{c}0.054 \\
(0.135)\end{array}$ & $\begin{array}{l}-0.126 \\
(0.165)\end{array}$ & $\begin{array}{c}0.969^{* * *} \\
(0.273)\end{array}$ \\
\hline 2004 & $\begin{array}{l}-0.023 \\
(0.133)\end{array}$ & $\begin{array}{c}0.139 \\
(0.155)\end{array}$ & $\begin{array}{c}0.445 \\
(0.294)\end{array}$ \\
\hline Constant & $\begin{array}{c}-2.295^{* * *} \\
(0.373)\end{array}$ & $\begin{array}{l}-0.865^{* *} \\
(0.405)\end{array}$ & $\begin{array}{c}-2.206^{* * *} \\
(0.536)\end{array}$ \\
\hline Observations & 4,291 & 4,291 & 4,291 \\
\hline Log Likelihood & $-2,662.721$ & $-1,938.768$ & $-1,454.589$ \\
\hline
\end{tabular}

